Portland State University

PDXScholar

2-22-1973

\title{
The Characteristics and Genesis of Stone Stripes in North Central Oregon
}

John Baine Pyrch

Portland State University

Follow this and additional works at: https://pdxscholar.library.pdx.edu/open_access_etds

Part of the Geography Commons, and the Geology Commons

Let us know how access to this document benefits you.

\section{Recommended Citation}

Pyrch, John Baine, "The Characteristics and Genesis of Stone Stripes in North Central Oregon" (1973). Dissertations and Theses. Paper 1610.

https://doi.org/10.15760/etd.1609

This Thesis is brought to you for free and open access. It has been accepted for inclusion in Dissertations and Theses by an authorized administrator of PDXScholar. Please contact us if we can make this document more accessible: pdxscholar@pdx.edu. 
AN ABSTRACT OF THE THESIS OF John Baine Pyrch for the Master of Science in Geography presented February 22, 1973.

Title: The Characteristics and Genesis of Stone Stripes in North Central Oregon

APPROVED BY MEMBERS OF THE THESIS COMMITTEE:

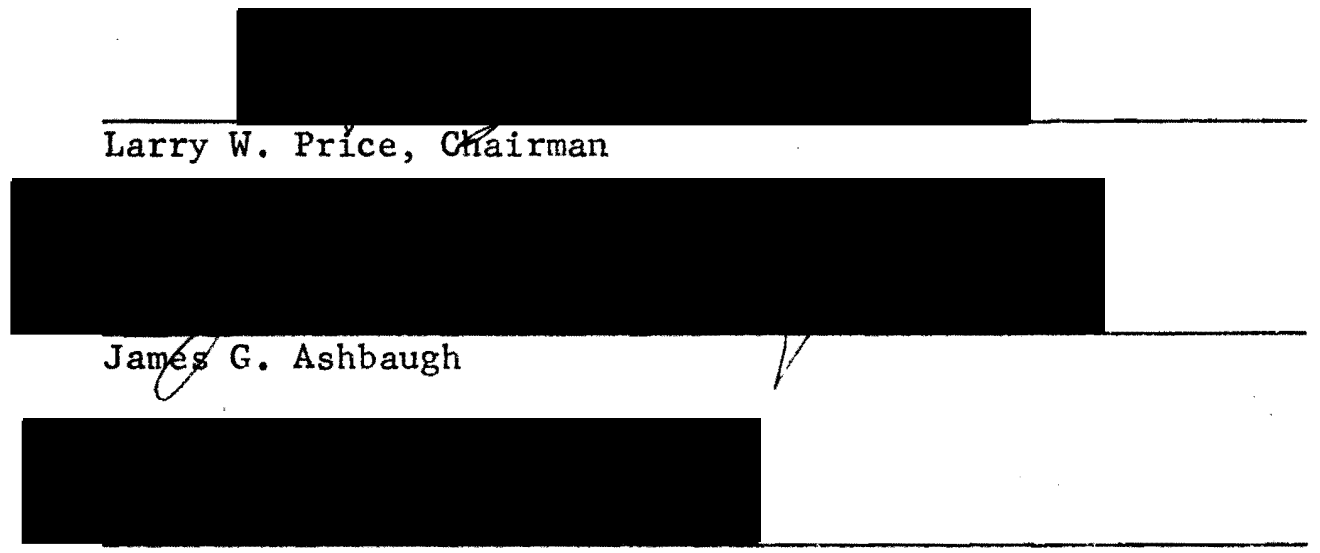

D. Richard Lycan

Stone stripes are linear accumulations of rock debris separated by finer material and oriented down the steepest available slope. In north central Oregon, the stone stripes are composed of basalt fragments and occur where the soil mantle averages less than $1 \mathrm{~m}$ in depth. They are best developed in areas of higher elevation, usually from about 900 to $1100 \mathrm{~m}$, and are most prominent on convex to straight slopes of 15 to 30 degrees. The stripes vary from a few meters to over 1.50 in length, and their widths range from 0.3 to over $3 \mathrm{~m}$. The depth of the stone stripes ranges from 20 to over $65 \mathrm{~cm}$. Morphological investigations of stone stripes in north central Oregon reveal that: (1) surface rock 
orientation is not very strongly related to slope direction or gradient; (2) stripe depth does not seem to be connected to width of the stripe nor to position on the slope; (3) vertical sorting occurs in a rock size ratio of about 5:3:2 from surface, to middle, to base; (4) the introduction of cattle has resulted in considerable stripe modification; and (5) vegetation encroachment and infilizing with soil are stabilizing the stripes from the edges inward.

The stone stripes found throughout north central Oregon are of such a size and magnitude that they cannot be adequately explained by geomorphic processes currently operating in the region. Although these processes are sufficient to cause some stripe movement and modification, the initial striped patterns were probably developed under periglacial conditions during the cooler, moister phases of the Quaternary. Evidence which lends credence to a cold climate origin for these stone stripes includes: (1) other forms of patterned ground, i.e.,. sorted circles, nets, and polygons; (2) soil mounds; (3) talus slopes; (4) terracettes; (5) convex slopes; and (6) stripe stabilization through vegetation encroachment, soil infilling, and heavy lichen growth. 
THE CHARACTERISTICS AND GENESIS OF STONE STRIPES

IN NORTH CENTRAI OREGON

by

JOHN BAINE PYRCH

A thesis submitted in partial fulfillment of the requirements for the degree of

\author{
MASTER OF SCIENCE \\ in \\ GEOGRAPHY
}

\author{
Portland State University \\ 1973
}


TO THE OFFICE OF GRADUATE STUDIES AND RESEARCH:

The members of the Cormittee approve the thesis of John Baine Pyrch presented February 22, 1973.

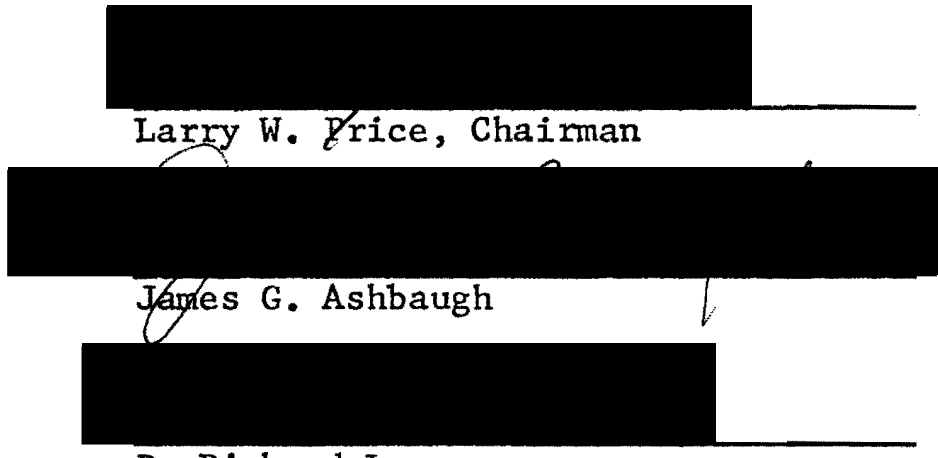

D. Richard Lycan

APPROVED :

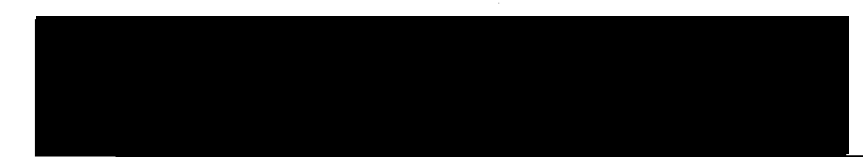

Dale E. Courtney, Head, Deparfment of Geography

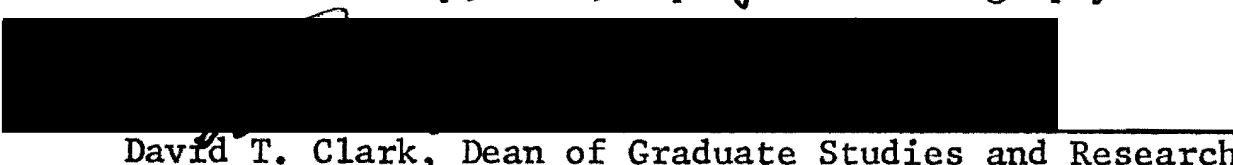

March 12, 1973 


\section{ACKNOWLEDGEMENTS}

I would like to take this opportunity to thank the faculty and staff of the Geography Department at Portland State University for their abundant assistance, counsel, and encouragement throughout the writing of this thesis and, indeed, throughout all my graduate work. A particular debt of gratitude is owed to Dr. Larry W. Price whose knowledgeable questioning and good humored enthusiasm and prodding allowed no discouragement. Mr. Bill Mulkey and Mr. Lester Holmes of the United States Department of Agriculture in Portland made air photos of the study area available and I am grateful for their help. I am also indebted to my brother Mark Pyrch, to Roy Rowden, and to my unsuspecting friend from Mexico City, Señor Marco Leopoldo Suárez Carrera. I am sure none of them realized the type of work involved when he volunteered to assist with my field work. My family all assisted in various ways. My mother, Paddy Pyrch, and my sister, Melinda Pyrch, were helpful with editing and duplicating. My wife, Gerri, gave constant assistance, and indeed, made this thesis possible. I give her my love and gratitude. 
TABIE OF CONTENTS

PAGE

ACKNOWLEDGEMENTS ..................... ili

LIST OF TABLES . . . . . . . . . . . . . . . . v vi

LIST OF FIGURES . . . . . . . . . . . . . . . . vii

CHAPTER

I INTRODUCTION .................. 1

II AREAL SETTING ................. 3

Physiography ................ . . 3

Geology ...................... 6

Soils .................. 8

Climate ........................ 12

Vegetation . . . . . . . . . . . . 17

Human Use . . . . . . . . . . . 19

III LITERATURE REVIEW . . . . . . . . . . . . 22

Patterned Ground . . . . . . . . . . 22

Stone Stripes . . . . . . . . . . 29

Thesis Area Studies .......... 32

IV METHODOLOGY ..................... 41

V ANALYSIS OF STONE STRIPES . . . . . . . . . 44

Individual Stripe Descriptions ........ 44

Study Site Number One

Study Site Number Two

Study Site Number Three 
Study Site Number Four

Study Site Number Five

Study Site Number Six

Summary and Integration . . . . . . . . . . . 84

VI CONTEMPORARY GEOMORPHIC ACTIVITY • • • • • • • • • • . 92

Modification by Man's Influence . . . . . . . . . 92

Rates of Surficial Rock Creep . . . . . . . . . 94

Painted Rock Measurement Site A

Painted Rock Measurement Site B

Painted Rock Measurement Site C

Painted Rock Measurement Sites D, E, \& F

Importance of Present Processes . . . . . 103

VII STONE STRIPE ORIGIN . . . . . . . . . . . 111

VIII RECOMMENDATIONS FOR FURTHER STUDY . . . . . . . . 122

REFERENCES CITED • • • • • • • • • • • • • • • • • • • • • 124

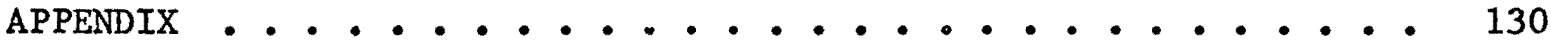




\section{LIST OF TABLES}

TABLE

PAGE

I Climatic Data from Stations on and Adjacent To the

Deschutes-Umatilla Plateau ..........

II Summary of Individual Stripe Measurements at

Cross Sections ..................

III Summary of Rock Size Measurements . . . . . . . . 
LIST OF FIGURES

1 Geomorphic subdivisions of the Columbia Intermontane Physiographic Province . . . . . 4

2 Generalized relief map of the Deschutes-Umatilla

Plateau ................ . . 5

3 Geology of the Deschutes-Umatilla Plateau . . . . . 7

4 Generalized soil map of the Deschutes-Umatilla

Plateau . . . . . . . . . . . 10

5 Relationship between station elevations and monthly

frequency of diurnal freeze-thaw cycles on the

Deschutes-Umatilla Plateau, 1962-1971 ....... 14

6 Average annual number of days with freezing tempera-

tures for stations on the Deschutes-Umatilla

Plateau, 1962-1971 ............. 16

7 Generalized vegetation map of the Deschutes-Umatilla

Plateau . . . . . . . . . . . 18

8 Schematic diagram of patterned ground development . . . 24

9 Schematic diagram of successive stages in the development of sorted circles and polygons ........ 27 
10 Generalized cross section diagram of a north central

Oregon stone stripe ...............

11 Distribution of study sites on the Deschutes-

Unatilla Plateau ...............

12 Stone stripe number one .............. 46

13 Surface rock orientation diagram for stripe number one - . 48

14 Composite diagram of stone stripe cross sectional

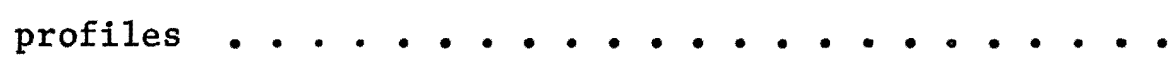

15 Rock size measurements for stripe number one . . . . . 50

16 Stone stripe number two . . . . . . . . . . 52

17 Surface rock orientation diagram for stripe

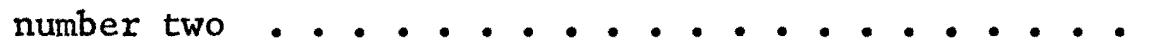

18 Rock size measurements for stripe number two . . . . 55

19 Head, center, and toe cross sections of stripe number two ...................

20 Stone stripe number three . . . . . . . . .

21 Vegetation encroachment and terracettes on stripe number three ..................

22 Surface rock orientation diagram for stripe number three .................. 
23 Rock size measurements for stripe number three . . . . .

24 Stone stripe number four . . . . . . . . . .

25 Surface rock orientation diagram for stripe number four ..................

26 Rock size measurements for stripe number four . . . . .

27 Stone stripe number five . . . . . . . . . .

28 Surface rock orientation diagram for stripe number five ...................

29 Rock size measurements for stripe number five .....

30 Head cross section of stripe number five . . . . . .

31 Stone stripe number six . . . . . . . . . 74

32 Surface rock orientation diagram for stripe number six....................

33 Rock size measurements for stripe number six ......

34 Vegetation encroachment at the lower end of stripe number $\operatorname{six} . . . . . . . . . . . . . .$.

35 Stone stripe number seven .............

36 Surface rock orientation diagram for stripe number seven .................. 
37 Rock size measurements for stripe number seven . . . . 82

38 Interstripe material being forced on and into the edge of stripe number seven ............

39 Stone stripe distribution in north central oregon ....

40 Schematic diagram showing how terracettes modify a stone stripe ...................

41 U. S. D. A. air photo showing the slopes where painted rock measurement sites were established ...

42 Painted rock measurements for stripe A . . . . . .

43 Painted rock measurements for stripe B .........

44 Painted rock measurements for stripe C . . . . . . 100

45 Painted rock measurements on the steep NW facing slope . - 102

46 Frost heaved rocks on the Deschutes-Umatilla Plateau . . 104

47 Ice crystals formed on the underside of rocks in a stone stripe.............. 104

48 Flattened frost boil with recently exposed rocks . . . 106

49 Frost heaved and overturned vegetation . . . . . 106

50 Frost heaved and buried vegetation on a steep, NW facing slope that is covered with terracettes ... 107 
51 Maximum extent of glaciation and pluvial lakes in relation to the study area during the Quaternary ............. 118 


\section{CHAPTER I}

\section{INTRODUCTION}

Stone stripes are linear accumulations of rock debris separated by finer material and oriented down the steepest available slope. They occur in a variety of sizes and in a wide range of environments. Largescale stone stripes are well developed on many of the hillsides throughout the Columbia Intermontane Province of Oregon, Washington, and Idaho (Fig. 1). During the summer of 1970 , I became interested in the distribution and development of the stone stripes while participating in the geography summer field camp under the direction of Professor Larry $W$. Price, Portland State University. Preliminary investigations during this time revealed a general dearth of information concerning the origin, structure, and occurrence of these features. In fact, the distribution of patterned ground throughout north central Oregon had never been documented.

Upon further investigation, it became apparent that the origin of these curious features was quite controversial. Several authors had attributed their formation to a variety of causes. Included among these were surface erosion by water, bedrock joint patterns, and intense frost action. Moreover, these features may have important environmenta1/climatic implications since they have been interpreted as being cold climate phenomena. Also, there was an absence of detailed information on the shape, size, and characteristics of stone stripes throughout the 
region.

The purpose of this thesis is to investigate the origin of stone stripes in north central Oregon. My approach is to analyze in detail the morphology, composition, and distribution of these features. Both descriptive and quantitative studies of the various stone stripe characteristics are included. Two years of measurements of downslope movement in the stripe and interstripe areas are also reported. These studies are combined with an analysis of contemporary environmental conditions in order to evaluate the role of current geomorphic processes in stripe formation. Finally, all this information is synthesized in drawing some conclusions about the origin and significance of the stone stripes. 
CHAPTER II

AREAL SETTING

\section{PHYSIOGRAPHY}

The thesis research area is located in north central Oregon, in the area known as the Deschutes-Umatilla P1ateau (Dicken 1965). This is one of thirteen geomorphic units which make up the Columbia Intermontane Physiographic Province, forming the southern section of the Columbia Basin Subprovince (Freeman, et al. 1945) (Fig. 1). The Deschutes-Umatilla Plateau has the general form of an inverted right triangle with the hypotenuse, or southern edge, abutting the northern slope of the Blue Mountains; the western margin is situated along the base of the Cascade Range; and the northern boundary is formed by the Columbia River (Fig. 2).

The Deschutes-Umatilla Plateau is $250 \mathrm{~km}$ long from east to west and 15 to $115 \mathrm{~km}$ from north to south. The plateau surface descends gently northward, with elevations ranging from 100 to $200 \mathrm{~m}$ near the Columbia River, to over $1100 \mathrm{~m}$ along the southern edge near Shaniko, where it terminates as a steep escarpment (Fig. 2). With the exception of the Columbia River, the Deschutes and John Day are the only large streams that flow outside this geomorphic unit. They flow northward to the Columbia in steep-walled canyons incised as much as $900 \mathrm{~m}$ below the plateau surface (Fig. 2). Physiographically, the Deschutes-Umatilla Plateau is characterized by horizontally layered 


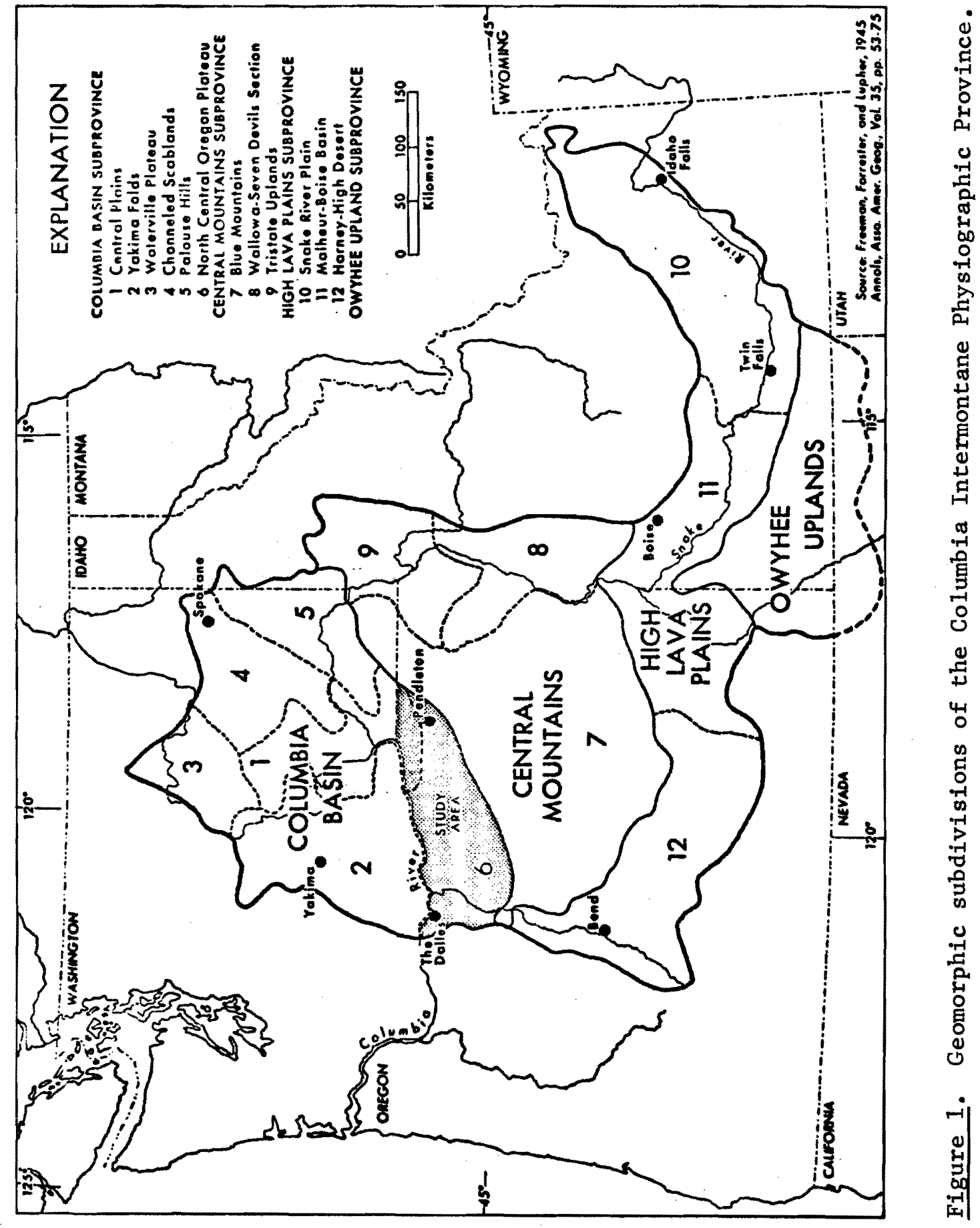




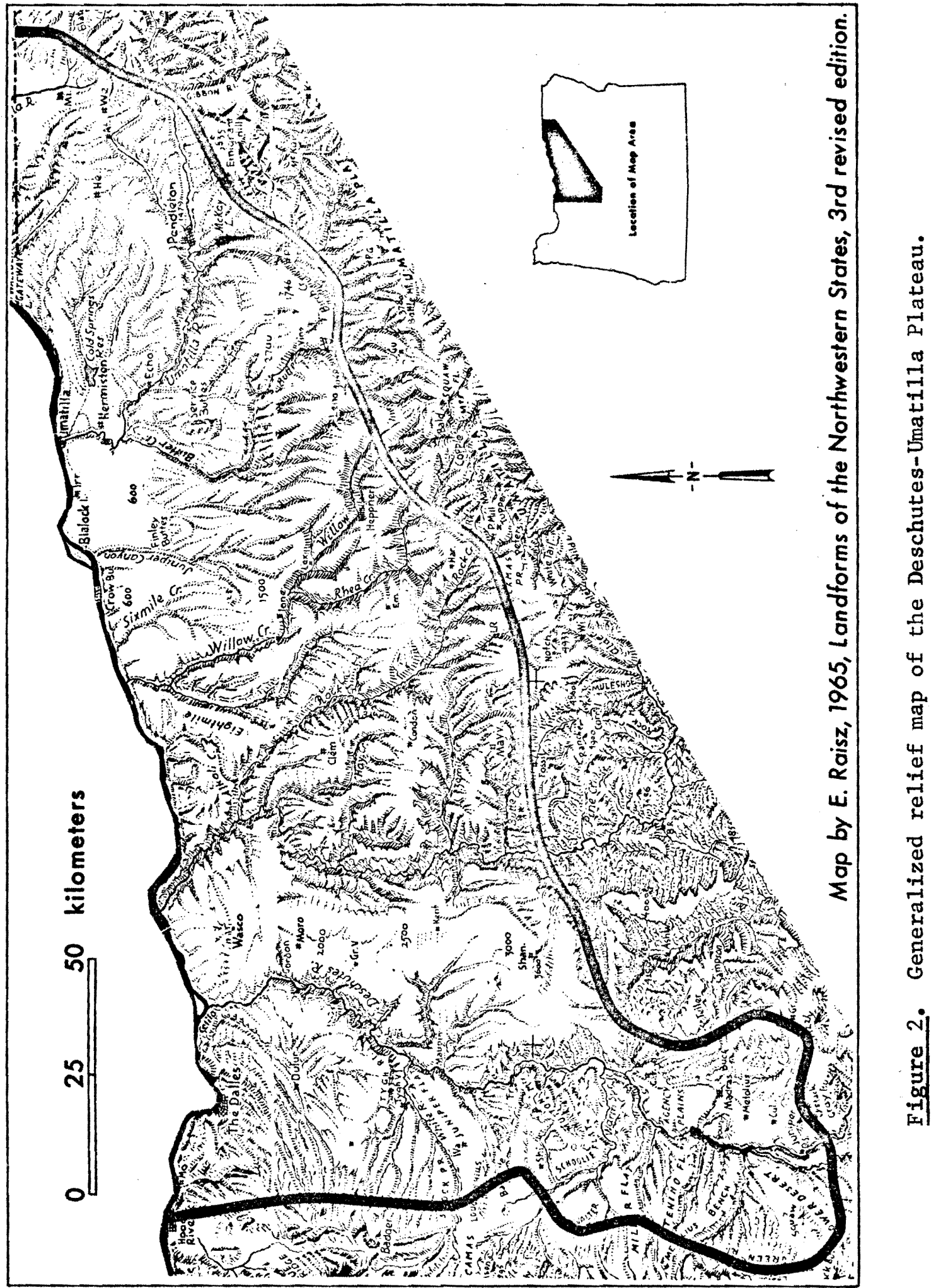


rocks, deep stream entrenchments, and broad interfluvial areas with little or no dissection (Dicken 1965, P. 131).

\section{GEOLOGY}

The most prominent rock type of the Deschutes-Umatilla Plateau is the vast volcanic sequence known as Columbia River Basalt (Fig. 3). This formation consists of dark basaltic lavas of Miocene to early Pliocene age with some interbedded tuffs near the surface (Newcomb 1969, p. 60). The lava flows originated from surface fissures at various points in time and space, with the layers of lava, typically 7 to $30 \mathrm{~m}$ in depth, stacked one on top of the other (Baldwin 1964, p. 88). The rock is commonly fine-grained, dark-gray, dense basalt in the massive sections of each flow, but near the upper margins, the rock becomes scoriaceous. The surface portion of each flow is oxidized and partly weathered, so that shades of red and brown are common. As the lava cooled, columnar structures formed at right angles to the flow surface. However, where deep cracks allowed cooling, the columns radiate from the fissure (Baldwin 1964, p. 89). Many of the columns are smal1, averaging 0.5 to $1 \mathrm{~m}$ in length, while others are many meters in length and more than $0.3 \mathrm{~m}$ in diameter.

According to Newcomb (1969, p. 60), the Columbia River Basalt formation is the greatest area of lava on any continent. This widespread basalt series extends over $500,000 \mathrm{sq} \mathrm{km}$ in Washington, Oregon, and Idaho, and underlies virtually the entire Deschutes-Umatilla Plateau (Fig. 3). Depth averages more than $600 \mathrm{~m}$ and the greatest total depth in the study area is estimated to be over $900 \mathrm{~m}$. In the southern 


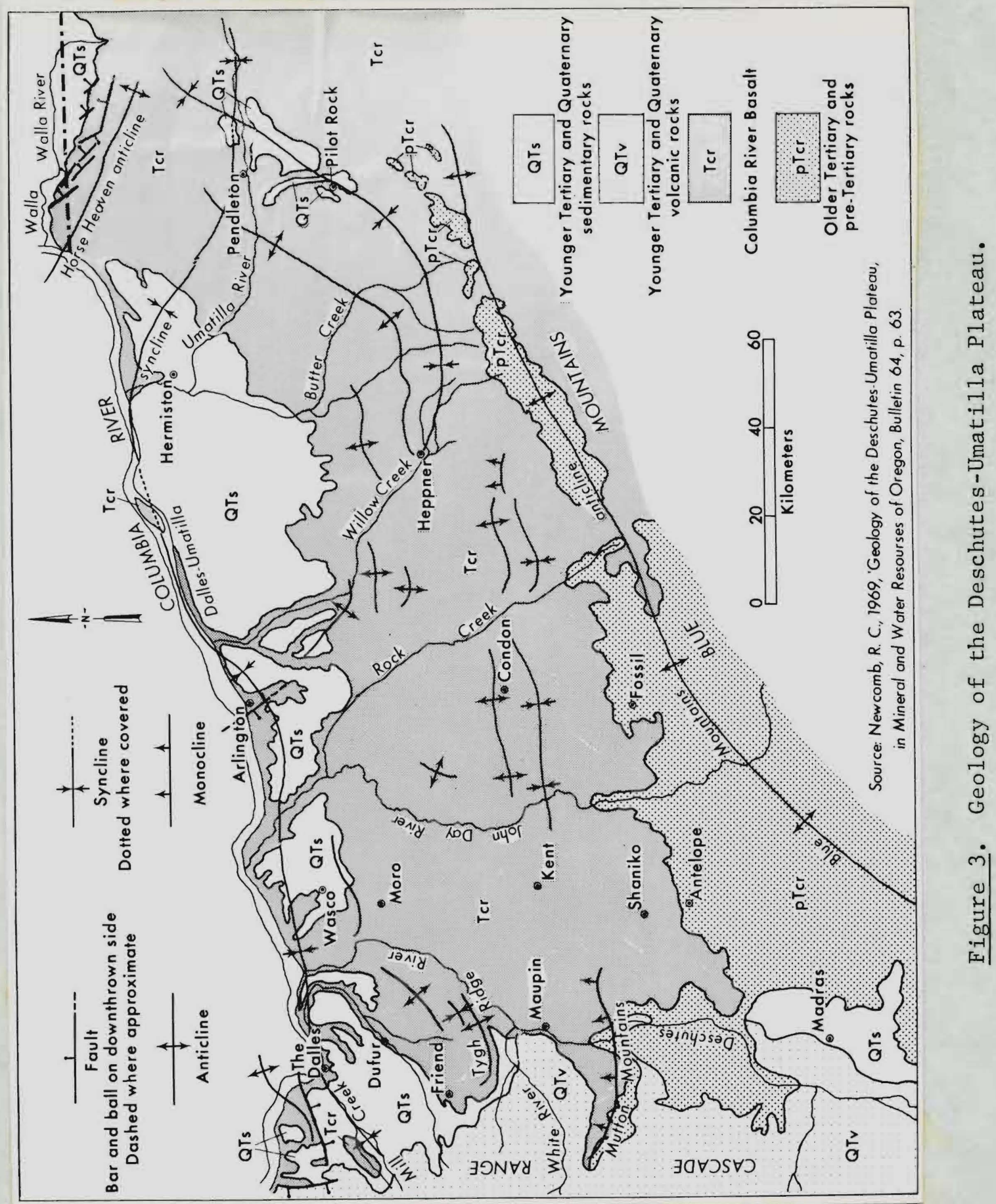


sections of the plateau the basalt thins, so that small areas of the older, underlying rock are exposed. However, these older, principally Tertiary rock units, such as the Clarno and John Day Formations, are not important on the plateau (Fig. 3). A relatively thin covering of sedimentary materials occurs on the plateau surface in the area between The Dalles and Pendleton and also over the older Tertiary and preTertiary rocks along the plateau's southwestern edge near Madras (Fig. 3 ). Pliocene to Holocene lava flows of the High Cascades extend on to the western sections of the plateau, covering both the sedimentary and older rock units that are situated along the eastern slope of the Cascade Range (Fig. 3).

The Deschutes-Umatilla Plateau is the southern limb of a long, wide, asymmetrical syncline which dips northward 0.5 to 3 degrees from the Blue Mountains to the Columbia River (Newcomb 1967) (Fig. 3). Subsidiary distortions form minor buttes, ridges, and valleys that interrupt the generally uniform, north-sloping surface. Among the largest of these subordinate features are the faulted anticline at Tygh Ridge and the Mutton Mountains (Fig. 3).

\section{SOILS ${ }^{1}$}

The Deschutes-Umatilla Plateau is mantled with a variety of soils which developed under grasses or shrub-grassland vegetation on loessial material. The deposits become thinner, and to some extent finer in

$1^{1}$ The soils of the study area have recently been discussed and mapped in a detailed report entitled Oregon's Long Range Requirements for Water by the Oregon State Water Resources Board. Most of the following information has been abstracted from those sections of this comprehensive study which pertain to the thesis area. 
particle size, with increasing distance from the Columbia River. Therefore, it is assumed that the loess was blown from the Columbia River flood plain and adjacent sand plains during the Pleistocene (Dyksterhuis, et a1. $1969, \mathrm{p} .10$ ). Most of the broad soil differences on the plateau can be correlated with regional variability in annual precipitation and temperature (Franklin and Dyrness 1969, p. 26). Soils become darker, somewhat finer textured, and more leached as precipitation increases and temperature decreases. These conditions generally occur towards the western, eastern, and southern margins of the plateau where higher elevations prevail (Fig. 2).

Soils of the Deschutes-Umatilla Plateau are divided into four sections: (1) the Columbia River lowlands; (2) the thick loess-mantled region peripheral to the lowlands; (3) the extensive, thin loessmantled section which forms the plateau's southern boundary; and (4) the western margin which coincides with the lower eastern slope of the Cascade Range (Fig. 4). The third and fourth soil regions are of principal concern in this thesis, because it is in these sections where patterned ground is most prevalent.

The Columbia River lowland section is largely composed of immature, wind-worked soils that developed from unconsolidated sediments which overlie the nearly level Columbia River Basalt (Fig. 4). Located in an arid region where the annual precipitation averages 130 to $230 \mathrm{~mm}$, these soils are normally loose, light colored, coarse textured, we11-drained, and neutral to moderately alkaline in reaction (Norgren and Simonson 1969, p. 9). Subdued dune topography is common, owing to the intensity of the wind which funnels through the Columbia Gorge. 


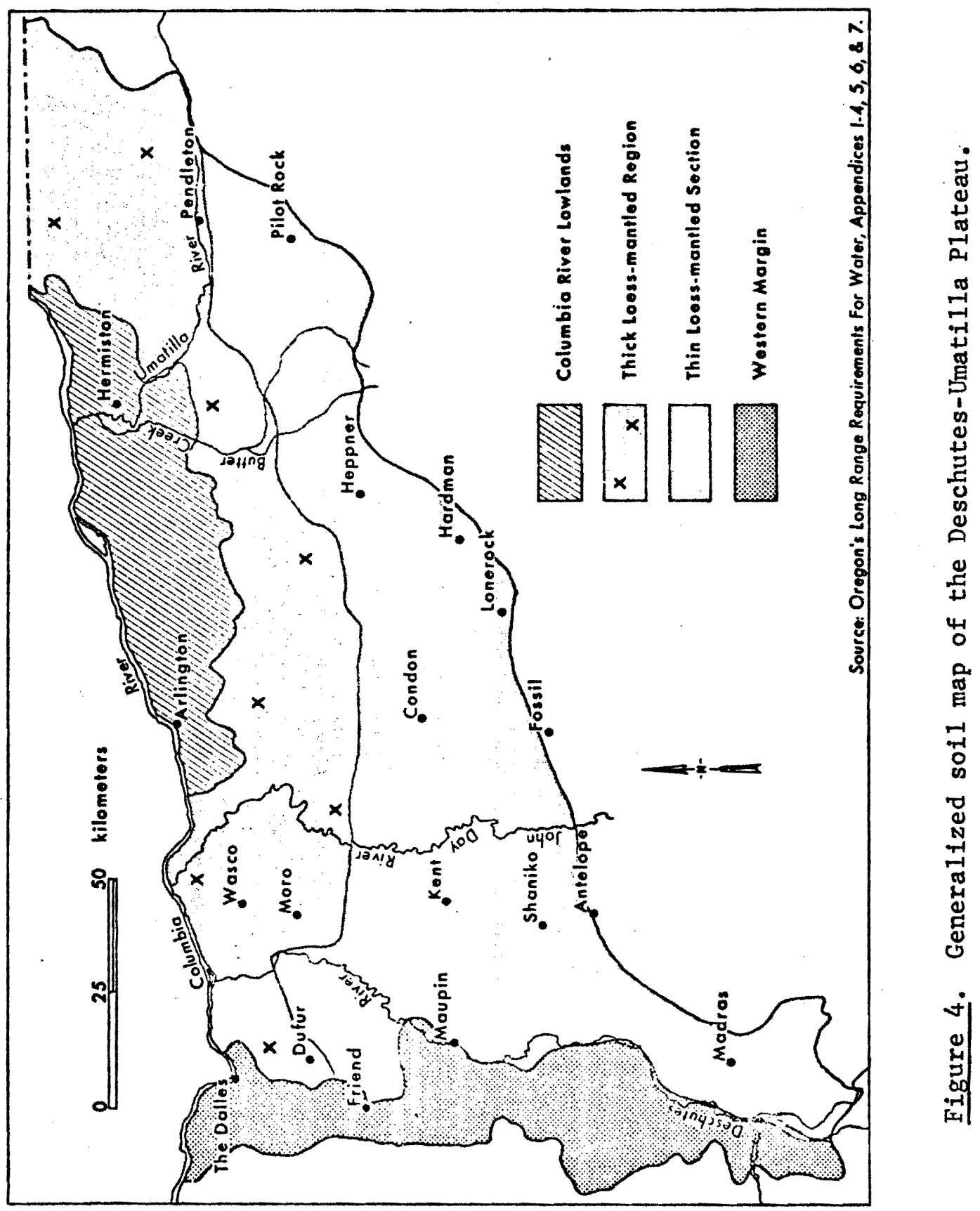


The Columbia River lowland section is surrounded by a second soil zone called the thick loess-mantled region (Fig. 4). In this area, silty, aeolian deposits blanket much of the landscape to depths of 1 to $30 \mathrm{~m}$, imparting a smooth, gently undulating topography. Much of this region is cultivated for small grain. These deep, stone-free soils receive 200 to $300 \mathrm{~mm}$ of annual precipitation. They are light to moderately dark colored, largely neutral in reaction, and quite productive (Norgren and Simonson 1969, p. 10).

A soil depth of roughly $1 \mathrm{~m}$ separates the thick loess-mantled zone from the thin loess-mantled region (Fig. 4). The soils of the thin loess zone are quite variable, ranging from moderately deep (40 to $100 \mathrm{~cm}$ ), dark colored, stone-free soils with medium silt loam texture to a very shallow (less than $40 \mathrm{~cm}$ ), extremely stony, silty to clayey 1oam. Better soils usually occur on relatively level basalt uplands, with poorer soils occurring on gently sloping to steep basalt areas. Throughout this zone, angular basalt fragments are frequently concentrated at the ground's surface forming a "stone pavement." This region of thin, poor soil is used primarily for grazing, with some small grain cultivation in the better soil areas. Annual precipitation ranges from 250 to $350 \mathrm{~mm}$ in this zone. The soil is normally slightly acid to neutral (Dyksterhuis, et a1. 1969; Norgren, et al. 1969, p. 15). The fourth and final soil zone is located west of the Deschutes River, along the east slope of the Cascade Mountains up to an elevation of $760 \mathrm{~m}$ (Fig. 4). The surface material consists of alluvium, loess, and volcanic ash underlain by lava flows which interfinger with volcanic sediments of The Dalles Formation (Norgren, et al. 1969, p. 15). This 
region, which forms a broad transition zone between the humid forested Cascade Range and the semiarid grassland plateau, has an average annual precipitation ranging from 250 to $450 \mathrm{~mm}$. The soils are mainly dark to grayish brown, shallow to moderately deep $(50-100 \mathrm{~cm})$, well-drained, with slightly acid to neutral reaction. These soils have a loam to clay or sandy loam texture and exhibit many similarities to the soils of the thin loess-mantled section.

The relatively shallow soils along the western margin of the plateau and the soils in the thin loess zone share an interesting characteristic. In both, there is a tendency for the soil to occur as sma11 mounds surrounded by very shallow, stony soils. This combination of mounds encircled by stone pavement forms a complex landscape called "biscuit" or "pimpled" topography. Although especially prominent near the plateau edges and on the narrow interfluve ridges, mound topography is characteristic of much of the landscape in the southern and western portions of the Deschutes-Umatilla Plateau (Fig. 4). It is in the stony intermound areas that the patterned ground features, which are of concern in this study, occur.

\section{CLTMATE}

The climate of the Deschutes-Umatilla Plateau is continental, but modified by marine influence from the Pacific Ocean. The region is characterized by low annual precipitation, moderately cold and relatively snow-free winters, and dry summers with warm to hot days and cool nights. Freezing can occur throughout the year, although the months of June, July, and August are generally frost free (Fig. 5). Diurnal 
fluctuations of $10^{\circ}$ to $16^{\circ} \mathrm{C}$ are typical, with daily variations of over $25^{\circ} \mathrm{C}$ not uncommon. The average annual temperature range is on the order of $22^{\circ} \mathrm{C}$, with the mean temperature of the coldest month (normally January) about $-2^{\circ}$ to $1^{\circ} \mathrm{C}$ (Table I). The lowest temperature ever recorded for this area was $-42.8^{\circ} \mathrm{C}$ at Madras in 1919 and the highest on record is $46.7^{\circ} \mathrm{C}$ for Pilot Rock in 1928. Absolute temperature extremes of $75^{\circ}$ to over $80^{\circ} \mathrm{C}$ have been recorded for many places on the plateau (Table I). Temperatures decrease with elevations away from the Columbia River, and concomitantly, the total number of frost days increases (Fig. 6 \& Table I). For example, Arlington (107 m), on the Columbia River, averages 80 frost days a year, while Fossil (811 m) and Madras $(688 \mathrm{~m})$, to the south, normally experience over twice this number (Fig. 6).

Precipitation on the Deschutes-Umatilla Plateau is primarily cyclonic in origin. However, the amount is considerably less than would be expected from frontal activity, because the region lies in the rainshadow of the Cascade Mountains. Mean annual precipitation ranges from 220 to $400 \mathrm{~mm}$, although the total varies greatly by locality and year (Table I). Snow accounts for only about 17 percent of the annual precipitation total. Summers are droughty to very dry, since less than 9 percent of the annual amount of precipitation occurs during this time (Table I). Convectiona1 storms develop periodically during the summer months, but their overal1 importance as a source of moisture is localized and of minor significance in the yearly totals. 


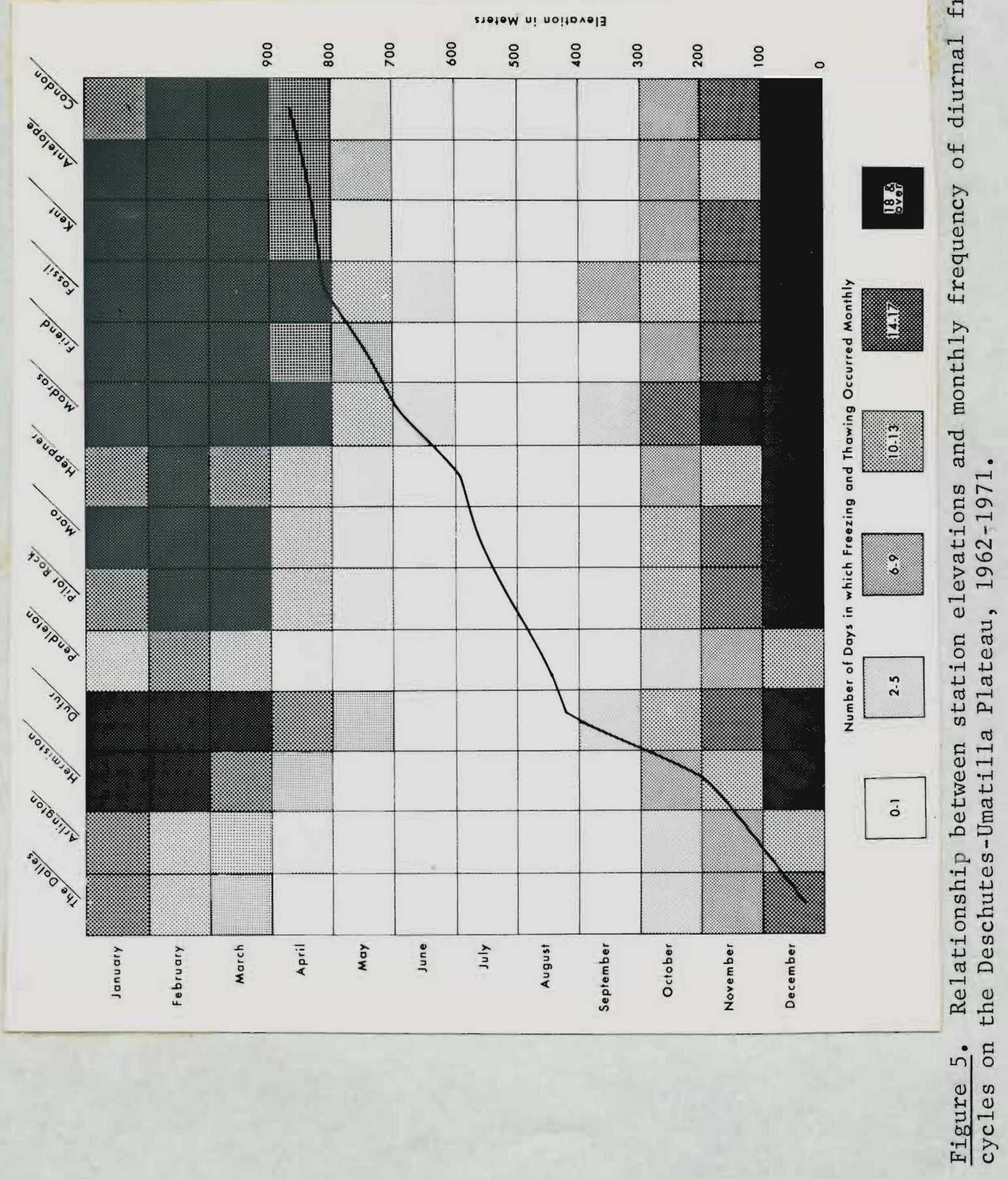




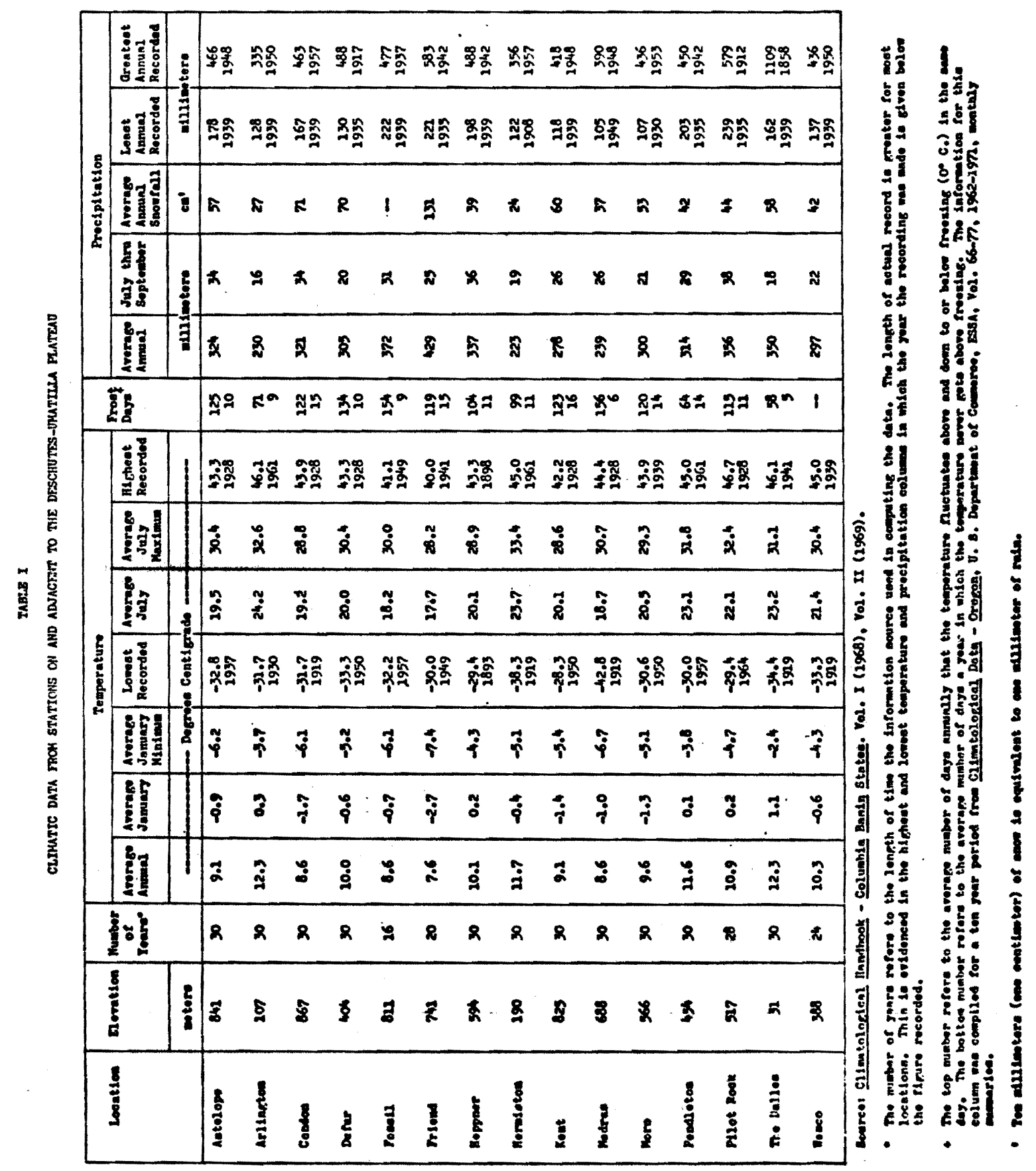


s1010W U! U0!101913

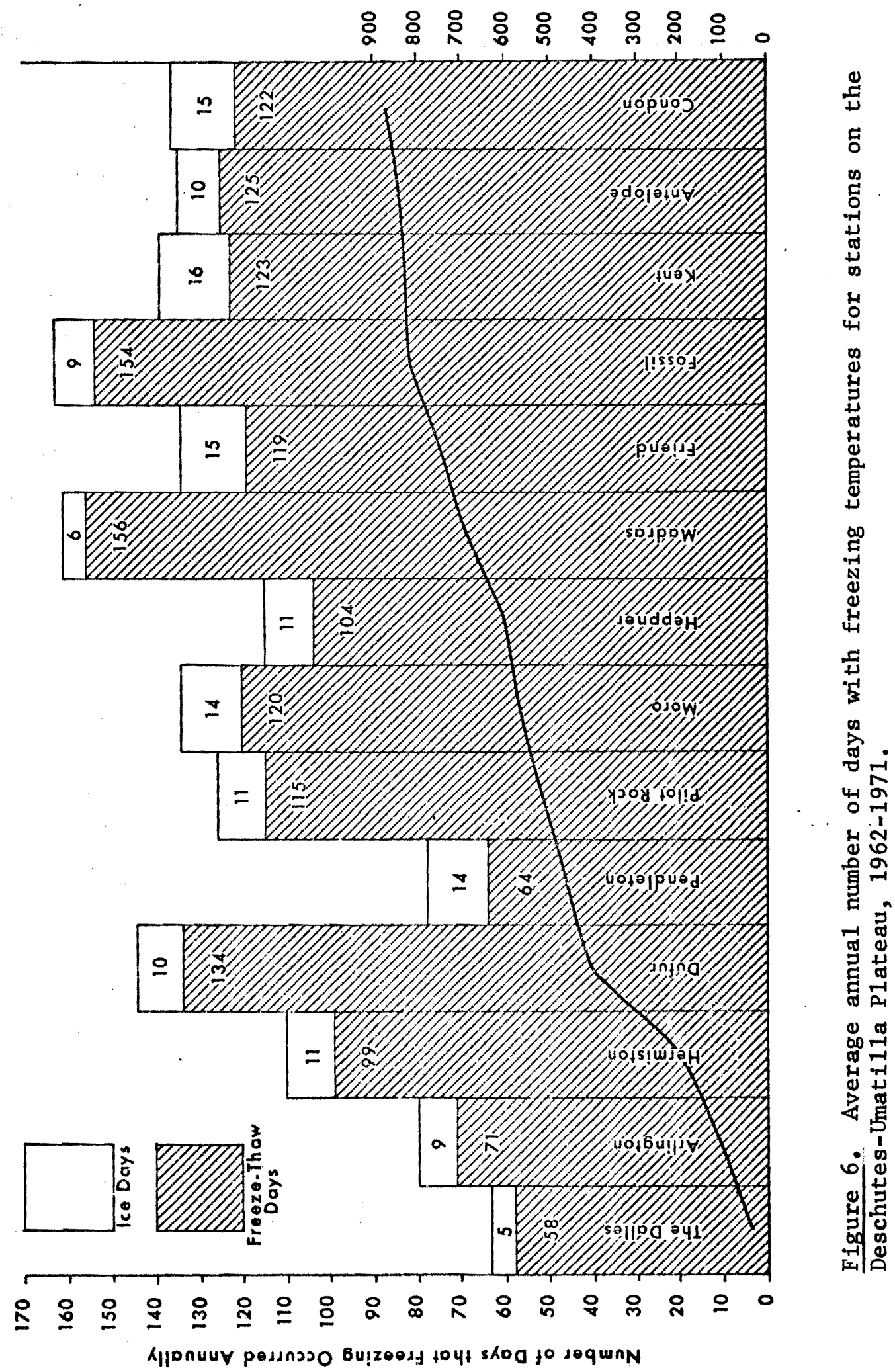




\section{VEGETATION}

The Deschutes-Umatilla Plateau is largely a region of steppe and shrub-steppe vegetation composed of bunchgrass and sagebrush communities (Fig. 7). Typically community dominants include: (1) shrubs, such as sagebrush (Artemisia spp.), Rabbitbrush (Chrysothamnus spp.), Bitterbrush (Purshia tridentata), and Shadescale (Atriplex confertifolia); (2) large perennial grasses, such as Bluebunch wheatgrass (Agropyron spicatum), Idaho fescue (Festuca idahoensis), Blue wildrye (E1ymus glaucus), and Thurber needlegrass (Stipa turberiana); and (3) introduced species, such as Cheatgrass (Bromus tectorum), Kentucky bluegrass (Poa pratensis), and Medusahead wildrye (Elymus caput-medusae) (Franklin and Dyrness 1969 , p. 140).

There is a pronounced absence of tree-dominated communities on the Deschutes-Umatilla P1ateau. In genera1, what trees that occur are confined to higher slopes with increased precipitation, or to riparian sites with adequate moisture. The western edge of the plateau has a zone of Western juniper (Juniperus occidentalis) that serves as an ecotone between Ponderosa pine (Pinus ponderosa) forests of the higher, more moist areas to the west and the shrub-steppe vegetation of the drylands to the east (Fig. 7). The natural, wide spacing of the juniper provides a savanna-type landscape and is characteristic of canyon bottoms, north-facing slopes, and places having slightly greater elevations.

The native perennial grasses, e.g., Bluebunch wheatgrass (Agropyron spicatum) and Idaho fescue (Festuca idahoensis), are nutritious but lack the ability to withstand heavy grazing. Daubenmire $(1970, p .7)$ 


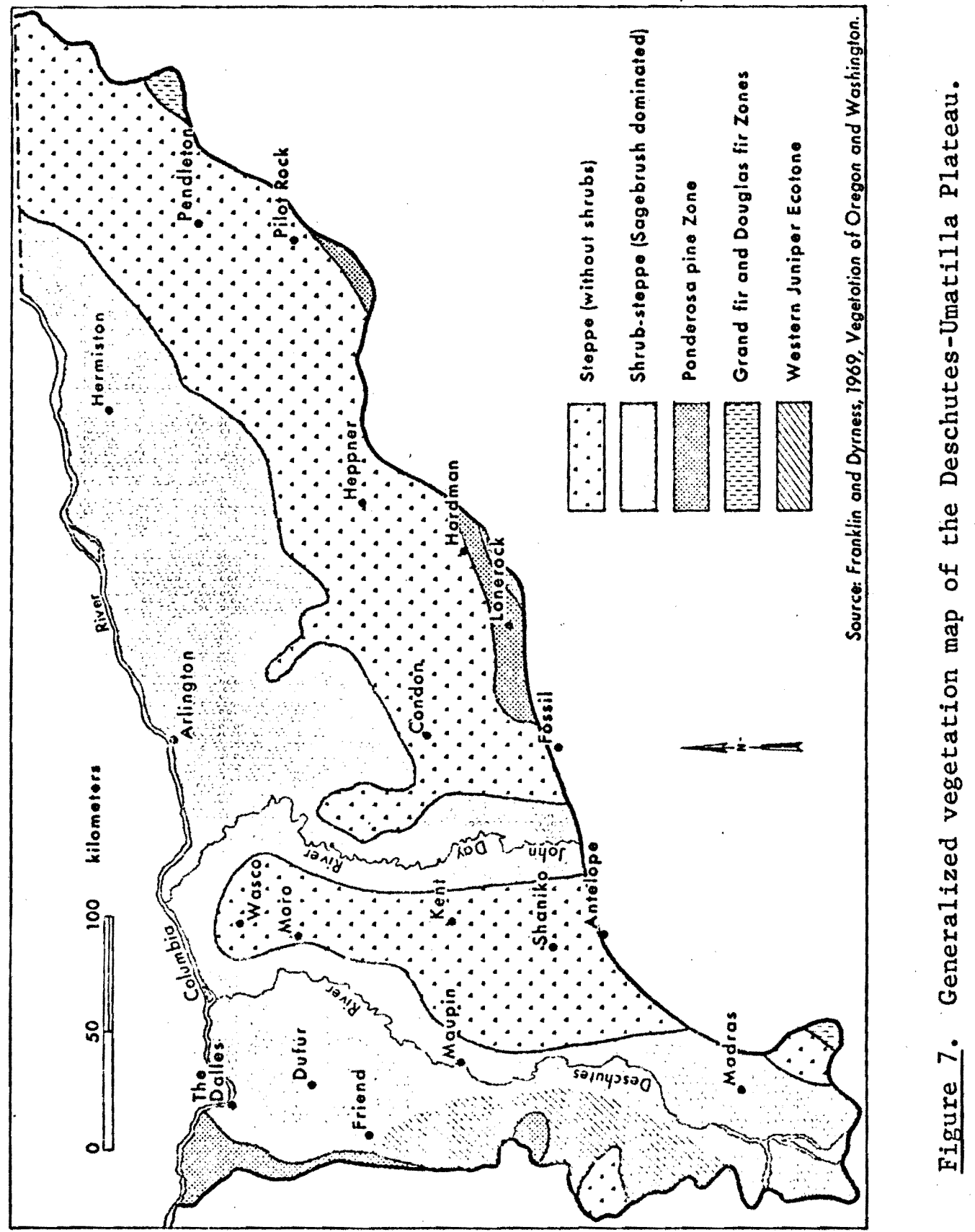


suggests that this has come about because ungulate pressure did not play a significant part in the evolution of these grasses. Therefore, the native grass species did not develop rapid recovery mechanisms to cope with excessive use. As a result, the grasses of the region rarely regain their former population densities after over-grazing and usua11y relinquish their territory to sagebrush (Artemisia spp.) and to the highly competitive introduced species, notably Cheatgrass (Bromus tectorum) and Kentucky bluegrass (Poa pratensis). With better control of grazing in recent years, the natural grasses are slowly returning in some areas.

The sections of shallow, stony soils found largely in the southern and western Deschutes-Umatilla Plateau are of principal concern here (Fig. 4). These regions exhibit abrupt vegetation changes between areas of relatively deep soils, e.g., mounds, and thin, rocky soils, e.g., stone pavement (Daubenmire (1970, pp. 37-48). The hardy, low statured Stiff sagebrush (Artemisia rigida)/Sandberg bluegrass (Poa secunda) vegetative association is widespread in the shallow, stony areas. It stands in marked contrast to the relatively luxuriant Big sagebrush (Artemisia tridentata)/Bluebunch wheatgrass (Agropyron spicatum) association found on the deeper, better drained soils of the mounds and other areas of thick soil mantle.

VI. HUMAN USE

Human development on the Deschutes-Umatilla Plateau has taken place mainly along the Columbia River and its tributaries. In prehistoric times, Indian groups were bound largely to the river system by 
one abundant resource - the salmon (Meinig 1968, p. 20). Some tribes settled permanently at key fishing sites, while others returned seasona1ly to replenish their supplies. Historically, the Columbia River has been the principal transportation and communication route from the interior of Oregon and Washington, through the Cascades, to the Pacific Ocean. Early explorers, traders, and settlers relied on this main thoroughfare for their activities. They located their towns where rapids or falls necessitated a freight-breaking operation. Later, other villages were founded as hinterland support centers. The present settlement pattern reflects the early reliance on the Columbia River and on the agricultural economy of the hinterland.

Today, the Deschutes-Umatilla Plateau is used mainly for farming and grazing. Since most of the valley floors are too narrow for cultivation and too deep to supply water to the uplands economically, dry farming is widespread, and irrigation is limited to a few favored areas (Dicken 1965, p. 132). Wheat is the principal crop, with both winter and spring varieties grown, chiefly in the thick loess-mantled zone (Fig. 4). A winter wheat/fallow rotation is practiced on most of the plateau, where the soils are relatively level and sufficiently deep to d1low the accumulation of a moisture reserve. Other small grains, such as barley, rye, and oats are grown throughout the region. In the northeastern sections of the plateau, where precipitation is heavier, it is common practice to alternate wheat with peas.

Cattle were introduced to the plateau on a large scale in the early eighteen hundreds, and sheep were brought in somewhat later. The former were generally more important until about the $1880^{\prime}$ s, when 
restriction of open-range practices limited the cattle industry in the better grass-producing areas of the thick loess-mantled zone (Meinig 1968, p. 284). A vigorous sheep industry continued until about 1940. At present, domestic livestock grazing is important in the marginal, southern sections of the plateau, where the soils are thin and stony. The severe reduction of native bunchgrass rangelands and the presence of the ubiquitous terracettes on hillslopes are evidence of the intense grazing that has taken place on this plateau. 
CHAPTER III

LITERATURE REVIEW

I. PATTERNED GROUND

Patterned ground is one of the most prominent and distinctive features of periglacial regions. 1 These "structure soils," as they were formerly called (Troll 1958, p. 1), have attracted an overwhelming literature with a host of names and numerous theories of origin. A major paper was published by A. L. Washburn in 1956 entitled "Classification of Patterned Ground and Review of Suggested Origins," in which he synthesized most of the literature and proposed a classification of patterned ground. There was much confusion and limited acceptance of earlier classifications because of their genetic implications and inconsistent nomenclature. Washburn's classification was entirely descriptive and incorporated a revised terminology that was coherent and orderly. It has met with much success and is now considered the principal method of arrangement for such phenomena.

Washburn (1956, p. 824) initiated his classification by defining patterned ground as follows:

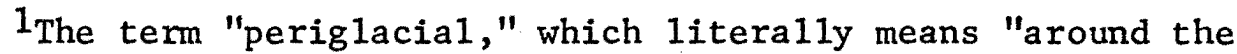
glacier," was introduced by the Polish geographer W. von Lozinski (1909, pp. 10-18 in Washburn 1973, Chapter 1) to designate the formerly more severe climates and climatically controlled features adjacent to the Pleistocene continental ice sheets. Through time, many investigators have expanded the meaning of the word, so that in present employment "periglacial" usually implies nonglacial processes and features of cold and severe climates, regardless of age and/or proximity to glaciers. 
Patterned ground is a group term for the more or less symmetrical forms, such as circles, polygons, nets, steps, and stripes, that are characteristic of, but not necessarily confined to, mantle subject to intensive frost action.

His classification of such features was based on two main aspects:

(1) its geometric form and (2) the presence or absence of obvious sorting between stones and fine materia1. With this foundation, Washburn designated five basic forms according to the shape of the surface pattern - circles, nets, polygons, steps, and stripes. Circles and polygons are self-explanatory; nets denote a mesh that is intermediate between these two but which cannot properly be placed in either. All three types are usually restricted to relatively level ground. The steps are found on slopes and have a step-like form which normally results from some type of embankment that becomes elongated downslope. Often referred to as "garlands" (Sharp 1942, p. 277), steps are transitional to stripes, which in turn are indicative of a greater gradient and develop in essentially parallel fashion down the steepest available slope. In addition to form, Washburn subdivided each pattern into sorted and nonsorted varieites. In the sorted forms, there is typically a gradation from finer particles to coarser particles (Fig. 8). In nonsorted features there is no such obvious gradation, although vegetation may play a significant role in outlining the pattern.

As reviewed by Tro11 (1958), patterned ground is not restricted to one, or even a few, climatic regions, but occurs in a variety of environments. It tends to occur wherever noticeable changes in the volume of surface or near-surface ground layers exist, as a result of desiccation, thermal change, hydration, or other chemical alterations (Hunt and Washburn 1966, P. B-104). Intensive frost action forms are certainly 


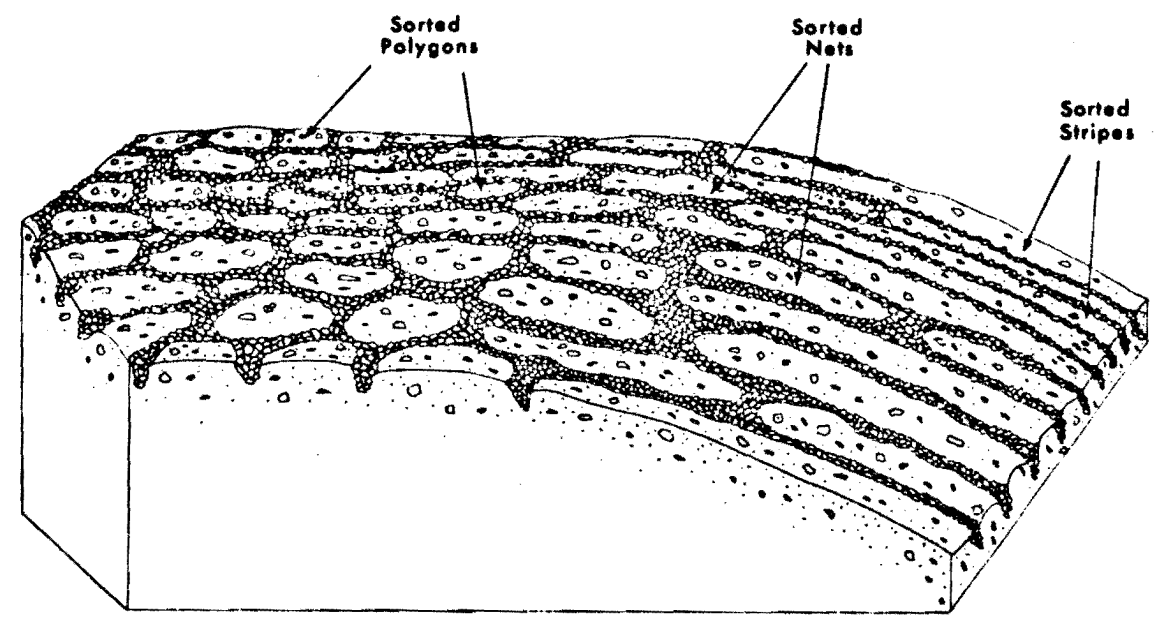

Figure 8. Schematic diagram of patterned ground development. Notice how the pattern becomes elongated on slopes because of mass wasting. (After Sharpe 1938, Figure 5, p. 37).

the most widespread; however, there is a propensity for the larger and better developed kinds to be associated with polar climates, especially in areas of permafrost. Several different types of patterned ground, many of them resembling those of cold regions, have developed in warm, arid climates, where solution and precipitation of salts and above freezing thermal changes have substituted for frost action (Hunt and Washburn 1966, p. B-104). It has also been reported that patterned ground tends to have a characteristic sequence related to altitude, with large sorted features being found in the highest zones as defined by Furrer (1965, p. 72 in Washburn 1973, Chapter 4).

The origin of many forms of patterned ground is far from satisfactorily explained. As a result, it is extremely difficult to separate the various kinds of patterned ground on the basis of origin. Rather, any overa11 explanation must be approached through individual processes (Washburn 1956, p. 859). For example, frost action processes 
are of major importance in the formation of many types of periglacial patterned ground, but they certainly are not the only processes involved. Washburn (1956, pp. 838-859) reviewed and summarized nineteen major hypotheses for the origin of patterned ground, and came to the following genera1 conclusions :

(1) the origin of most forms of patterned ground is uncertain; (2) patterned ground is polygenetic; (3) some forms may be combination products in a continuous system having different processes as end members; (4) climatic and terrain interpretation of patterned ground, both active and "fossil," is limited by lack of reliable data about formative processes (Washburn.1956, p. 823).

In spite of the inconclusive evidence, several general comments can be made with regard to major processes responsible for the genesis of patterned ground. Washburn (1956, pp. 859-860) determined that contraction because of drying or low temperature is probably important as a beginning process in the formation of polygonal patterns. He further concluded that local differential heaving and cryostatic movement are genetic processes of widespread significance in the creation of circular patterns. 1 Washburn also suggested that key processes, with respect to sorting, may include ejection of stones toward freezing surfaces by repeated freezing and thawing, movement by gravity, and eluviation of fines. In the formation of patterned ground on slopes, mass wasting is noteworthy, since it most likely combines with one or more of the other processes to yield the various elongated types of patterned ground that are restricted to slopes. Along with emphasizing the polygenetic nature of patterned ground, Washburn (1956, p. 859)

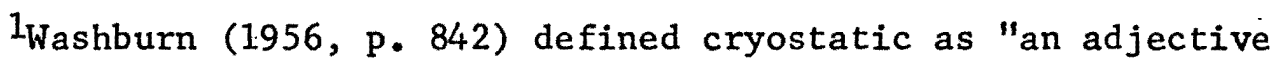
describing freezing-induced hydrostatic phenomena" and described cryostatic movement as movement by frost-generated hydrostatic pressure. 
conjectured that complexes of these processes function together, or in a series, and that similar forms can result from quite different processes, while different forms possibly can result from similar processes. In periglacial environments, the sorting of materials is principally the result of frost heaving and thrusting. These are related processes. Thrust is the predominantly lateral movement, and heave is chiefly an upward displacement (Eakin 1916, p. 76 in Washburn 1969, p. 50). It has been demonstrated that the pressures responsible for frost heaving and thrusting occur not only because of the 9 percent volume increase as water changes to ice, but more importantly, because of the growth of ice crystals when additional water is drawn to the freezing plane (Taber 1929, 1930; Beskow 1947). Pressure is exerted in the direction of ice crystal growth, i.e., at right angles to the freezing surface. Because freezing extends downward from the ground, or cooling plane, Taber (1943, pp. 1458-1459) stresses the role of frost heaving as opposed to thrusting. However, there are cases in which the reverse is true, owing to the different thermal capacities that are found in heterogeneous material (Corte 1962, pp. 14-17).

By it's very nature, and as a result of the various processes mentioned above, heterogeneous material will have some sections in which there are more fines than in others. These concentrations of fine material have a greater water-holding ability, and therefore a more pronounced expansion occurs within these nuclei upon freezing. Contraction results during thawing and the fines retreat together because of their greater cohesion, while the coarser material does not contract as far. After each freeze and thaw cycle the area of fines 
increases. This is accomplished at the expense of the coarse material, which is forced further outward and becomes more clearly isolated (Fig. 9). This process continues until the individual nuclei begin to impinge upon each other, forming sorted circles or sorted polygons (Washburn 1956, p. 838) (Fig. 9). Although the above discussion pertains largely to relatively horizontal surfaces, the same fundamental processes are at work on slopes, except that in this situation the patterns are elongated because of mass wasting (Fig. 8).

The mechanisms by which stones are ejected from fines through frost action are complex and poorly understood, especially in unconsolidated heterogeneous material. Washburn (1969, pp. 52-58) assembled the basic theories on this phenomenon into two groups: (1) the frostpul1; and (2) the frost-push mechanisms. The frost-pull hypothesis is based on the idea that when the ground expands during freezing it carries stones with it. During thawing, contraction takes place and
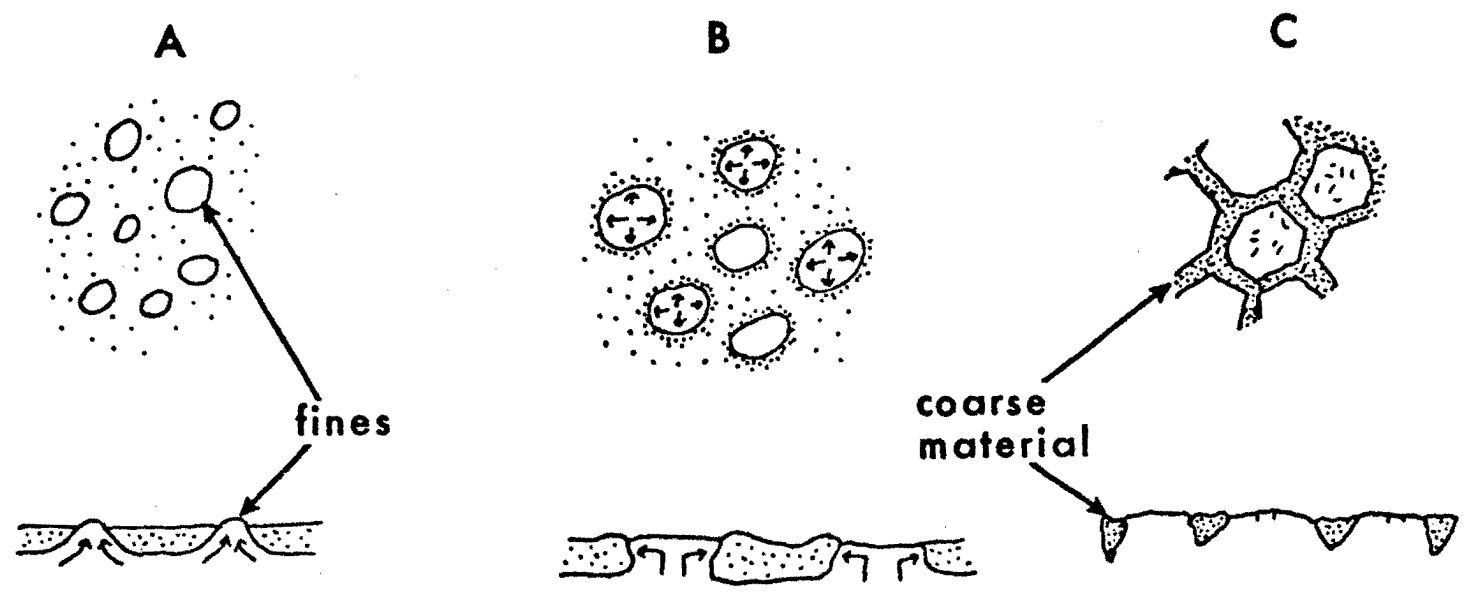

Figure 9. Schematic diagram of successive stages in the development of sorted circles and polygons in plane view (top) and in cross section (bottom). (After Dzulynski 1963, Figure 1, p. 146). 
the adhering fines infill behind the stones, so that the stones are unable to return to their initial position completely. Thus, several freeze and thaw cycles would lead to ejection of stones from fines upward. The frost-push concept suggests that upfreezing is explained by the greater thermal conductivity of stones than fines. Since stones heat and cool more rapidly than the soil, ice forms around stones, or at their bases, during freezing, and forces them up. The seeping-in of fines during thawing allows at least a part of the upward advancement of the stones to be retained. Through these predominantly vertical sorting processes, the larger particles may become concentrated at the ground's surface, in both coarse and fine material.

Although much more complicated than they appear to be in this review, these two processes are believed to be the major mechanisms in upfreezing of rocks. They are difficult to differentiate in the field since they operate simultaneously. The frost-pull mechanism is most likely more significant in the general ejection of stones. The frostpush mechanism is probably more important in the upward displacement of large stones because of their latent ability to quickly accumulate ice at their bases, owing to greater thermal conductivity (Washburn 1969, p. 58; Bowley and Burghardt 1971, p. 5). This analysis focuses on the upfreezing of stones that are completely, or at least partially, buried below the surface of the ground. Once stones reach the surface, additional processes, such as needle ice and frost creep, come into play.

There are many processes other than frost action which produce the sorting effects found in this type of patterned ground. For 
example, Hunt and Washburn (1966, p. B-130) point out the close similarities between processes in the highly saliferous ground of a hot desert and those in the ground distinguished by intense frost action. Desiccation and thermal changes subject the ground in both environments to contraction cracking, while crystal growth, salt and ice, can cause heaving and thrusting in each milieu. Similar forms of patterned ground result, in spite of the widely different climates and processes involved, although intense frost action has the ability to move much larger material.

Patterned ground exists in active, inactive (also designated relic), and fossil forms. Obviously, the active stage applies to features in which movement and instability are evident. Except for evidence of activity, relic structures have components similar to active types, and may become reactivated through environmental change. Lichen-covered rocks and vegetation types that cannot stand instability are examples of surface phenomena which demonstrate inactivity. Fossil forms may be revealed in cross section only, and are more distinctly irreversible in activity. Inactive and fossil features provide useful Indications of the climatic conditions which formerly existed within the region concerned. Because of particle segregation, relic and fossil sorted patterned ground are probably more easily recognized than nonsorted types (Washburn 1973, Chapter 4).

\section{STONE STRIPES}

Stone, or sorted, stripes are defined as "patterned ground with a striped pattern and a sorted appearance due to parallel lines of stones 
and intervening strips of dominantly finer material oriented down the steepest available slope" (Washburn 1956, p. 836). They have been divided into sma11 and large varieties by Washburn (1969, p. 177). Small sorted stripes are those whose width between center lines of similar linear elements is less than $1 \mathrm{~m}$. Some more or less corresponding terms include soil-strips, stone-bordered strips, and striate land (Huxley and Ode11 1924, p. 225); stone stripes, striped ground, and stone-bordered stripes (Sharp 1942, p. 275); rock stripes (Sigafoos and Hopkins 1952, p. 176); stone streams and, in Swedish, strenströmmar (Lundqvist 1962, pp. 97); in German, Steinstreifen, Streifenboden, and Steinbänder (Sharpe 1938, p. 38). In Siberia, they are known as dellies (Strelkov 1968, p. 1177).

Sorted stripes may occur on mantle derived from the subjacent bedrock, or on transported regolith. They appear to be solely surface phenomena and are restricted to slopes (Hay 1936, p. 48; Sharp 1942 , p. 278). Stone stripes may merge or extend from sorted horizontal surface features, i.e., circles, nets, and polygons, which become elongated because of mass wasting as the slope becomes steeper (Fig. 8). The gradient separating level ground structures from sorted stripes varies with local conditions. ${ }^{1}$ Stone stripes may also develop independently of these other forms and often are found without any circles, nets, or polygons upslope (Kaatz 1959, p. 150). The stripes become more regular in direction and in spacing as they descend the slope. There is

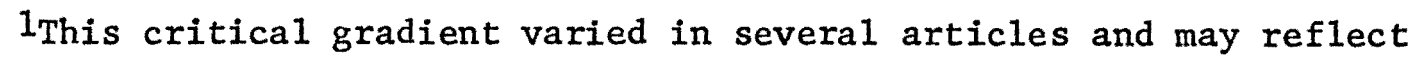
the different local conditions. For example, Richmond (1949, p. 146) observed an angle of $4^{\circ}$; Sharp (1942, pp. 277, 281, 295) reported $5^{\circ}$ to $7^{\circ}$; Sharpe (1938, p. 38) mentioned about $5^{\circ}$; Embleton and King (1968, p. 486) suggested $2^{\circ}$. to $6^{\circ}$; and Tricart $(1970, p .93)$ stated that "between $2.5^{\circ}$ and $7.5^{\circ}$, polygons are transformed into stripes." 
a certain distance of movement necessary before sorted stripes acquire their typical shape, although the authors neglected to include measurements or other qualifications pertaining to the relationships between this distance and the size of the features involved (Hay 1936, p. 48; Lundqvist 1962 , p. 56). Maximum slopes on which sorted stripes have been reported vary from $15^{\circ}$ (Richmond 1949, p. 146) to $30^{\circ}$ (Sharp 1942 , p. 281) and up to $33^{\circ}$ (Sharpe 1938, Plate IIIA facing p. 36).

Except for being confined to slopes, sorted stripes usually occur in the same areas as other types of sorted patterned ground. They are characteristic of polar, subpolar, and alpine environments, and the larger sorted kinds are commonly associated with permafrost, although it need not be present where miniature sorted ones develop. The contemporary nature of smal1, mid-latitude sorted stripes at relatively low elevations on permafrost-free ground has been recognized by several authors (Hay 1936; Denny 1940; Miller, et al. 1954; Caine 1963). Fossil and inactive forms have also been reported from a variety of middle latitude regions, and these forms may be due to more severe climatic conditions in the past (Denny 1940; Smith 1949a, 1962; Kaatz 1959; Brunnschweiller 1962; Malde 1961, 1964; Clark 1968). However, Washburn (1956, p. 837) felt that fossil stone stripes would rarely be preserved in stratigraphic section because they are slope phenomena. Sorted stripes occurring in Death Valley, California, further illustrate the fact that these features are not restricted to periglacial environments (Hunt and Washburn 1966, p. B-122). 
III. THESIS AREA STUDIES

Literature pertaining to patterned ground in the Columbia Intermontane Province deals chiefly with the curious biscuit, or pimpled, topography which is found throughout much of this region. As a result, the large-scale sorted patterned ground commonly associated with these ubiquitous microrelief features has been given only cursory treatment. Severa1 investigators, including Kaatz (1959) and Malde (1961, 1964), have designated these mounds as a type of patterned ground. The mounds do not fall logically within the category of patterned ground and are not included in Washburn's classification (1956). The problem of the mounds is beyond the present scope, but they are, nevertheless, closely associated with patterned ground in the study area, and numerous authors suggest that their origins are intimately related. A review of the literature dealing with these features is therefore in order. It should be kept in mind, however, that this close association between patterned ground and mounds does not necessarily imply that they were formed simultaneously or by similar processes. ${ }^{1}$

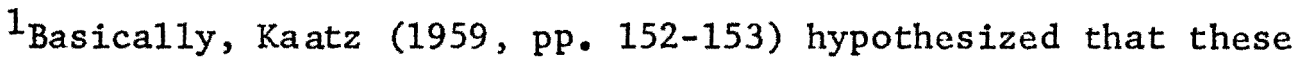
mounds are the remnants of ice wedge polygons which developed under a formerly more severe climate. His theory maintains that with a moderation of the climate, the ice wedges melted and material slumped into the remaining cavities. Solifluction, facilitated by snow melt and precipitation, removed the slumped soil and gradually formed a system of interconnected furrows which eventually subdivided vast areas into mounds. If his theory is correct, these mounds originated from a type of nonsorted patterned ground - the ice wedge polygon. However, as they exist today, these mounds do not, I believe, constitute patterned ground as defined by Washburn (1956). They should be considered as simply "mounds" until a more adequate definition, classification, and/ or terninology is developed. 
When Joseph LeConte traveled from The Dalles to the upper bridge of the Deschutes River (probably Sherar's Bridge) in 1873, he noticed several of the region's distinctive features, including stone stripes. He considered the mounds, the "long hill-side furrows and ridges" and the "wide pebble-covered spaces" as "remnants of a general erosion of the surface soil" (LeConte 1874, p. 366). The bare, treeless country and a finer, more moveable drift-soil above a coarser and less mobile subsoil resulted in the "peculiar conditions" which he felt caused these phenomena (LeConte 1877).

Since then, these characteristic soil mounds have been widely recognized throughout much of the Columbia Intermontane Province (Fig. 1). Piper (1905), Freeman (1926, 1932), and Olmsted (1963) discussed the mounds and their origin, but paid little attention to the intermound areas, and did not mention the presence of sorted stripes at a11. Waters and Flagler (1929), in their detailed study of three separate mound areas in the Columbia Basin, described sorted stone nets and stripes as "erosion furrows" Essentia11y, they agreed with LeConte and ascribed the genesis of the mounds to surface erosion which resulted in exposing the weathered basalt bedrock between the mounds. They discussed the development of "erosion furrows" on slopes near Maupin, Oregon, as follows:

Where there is an appreciable slope, however, erosion has cut through the unconsolidated ash exposing the relatively much more resistant basalt along the bottoms of narrow flatbottomed erosion furrows. Where the hillside has a slope greater than two degrees the erosion furrows extend downward exactly at right angles to the contours that define the hill. If the hill is round they radiate from its summit; if it has a gentle uniform slope they form long parallel lines which are rendered conspicuous by the contrast in color between the tawny brown ash and the black basalt. The main surface runoff within a single furrow is usually concentrated in a sma11 
channel near its center. These tiny channels, formed by local removal of the ash from between the loose angular blocks that floor the bottom of the furrow, appear as conspicuous black streaks along the center of the trench. The angular basaltic blccks that lie in the channel are not at a lower elevation and are of no larger size than those that cover the rest of the furrow (Waters and Flagler 1929, p. 215).

It would seem that these "conspicuous black streaks" or "channels" are coincident with the sorted patterned ground so prevalent in this area. Waters and Flagler (1929, pp. 215-223) further stated that "if the slope is less than one degree the charmels are no longer parallel but anastomose between the mounds, which in this case form an irregular pattern without marked alignment," thus "the intervening areas between the mounds form a definitely integrated and minutely adjusted drainage system" and "the symmetrical development of this drainage system may be influenced by the columnar jointing of the ash." Finally, they felt it unnecessary to assume that a climatic change occurred to account for these features, i.e., mounds and erosion furrows, since the fact that erosion is proceeding faster than deposition provides an adequate explanation.

C. F. S. Sharpe (1938, pp. 38-39, Plate IIIA) was the first to identify stone stripes in the Columbia Basin as a type of patterned ground. The following is a description of some stripes he found in central Washington:

At that locality well-defined stripes averaging four feet wide start near the top of a hillside, where there are sporadic outcrops of basalt, and continue directly or sometimes diagonally down the slope. Stripes may be straight and single or very irregular; two may join for a short distance and separate again, forming broad belts, loops, and other forms. Sections cut across these stone-stripes at two places showed that they were composed largely of blocks of scoriaceous basalt three to six inches in diameter, although other sizes from one inch to 
one foot were present. The stripes contained no fine matter and at a depth of eight to twelve inches below the ground surface the type of material that had appeared in the stripes ceased abruptly and soil comparable to that of the interstripe areas was entered (Sharpe 1938, pp. 38-39).

Sharpe recognized their similarity in appearance and structure to those described from cold climates and implied that they may have originated under periglacial conditions during the Pleistocene. He also suggested that the stone stripes in central Washington appeared to be active still and described them as being solifluction phenomena.

In analyzing the occurrence of mound topography in the United States, Knechtel (1952) also discussed the presence of stone stripes in the Columbia Basin. He suggested that they express, in part, the polygonal jointing in the basalt bedrock, and that the sorted ground patterns or "intermound furrow systems" originated from such cracking (Knetchel 1952, pp. 692-693). His examination of aerial photographs taken near Shaniko, Oregon, prompted the succeeding discussion of stone stripes :

In the gently sloping ground just above the rim of the canyon are many evenly spaced, straight furrows which appear to follow the systems of parallel joints trending most nearly at right angles to the topographic contours, that is, in the direction of slope. Accordingly, the furrows on the prominent, rounded spur east of the canyon show a distinct radial pattern, as do also those of mound-studded areas in other parts of the area. The intermound furrow patterns in the vicinity of Shaniko seem therefore to be genetically associated with columnar jointing in the underlying basalt (Knetche1 1952, p. 693).

These bedrock joint patterns have concentrated the surface runoff, according to this theory, and the resulting "furrows" developed in much the same manner as that suggested by LeConte $(1874,1877$ ) and Waters and Flagler (1929). 
Kaatz's study of mounds and patterned ground in central Washington suggested that sorted stone features not only seem to be associated with the distribution of shallow aeolian deposits in Oregon, Washington, and Idaho, but also with the recent lava flows in these states (Kaatz 1959, p. 146). He felt that the mounds, sorted stone nets, polygons, and stripes were all related, even though these features, especially the sorted stripes, were not found in affiliation everywhere. Kaatz (1959, pp. 146-147) indicated that the distribution of these forms differed with drainage characteristics, soil mantle, slope, and depth to bedrock. He stated that these various features are found on an assortment of parent material, although he neglected to specify which features are found on which type.

Kaatz (1959, pp. 148-152) stated that the sorted ground patterns occupied the barren intermound areas and that they were composed of subangular basalt blocks and rubble that often fitted tightly together "as in a jigsaw puzzle." He mentioned that the large slab-shaped fragments frequently were standing on edge and that the size of the basalt rocks decreased with depth, as did the width of the sorted features. Where the gradient increased, stone nets and polygons formed sorted stripes, which were variable in width and length. He also noted that the sorted nets, polygons, and stripes did not occupy the lowest point between the mounds and because of this, suggested that water erosion cannot adequately explain their development. Kaatz (1959, p. 152) maintained that most of the mounds and associated patterned ground features were principally the result of intensive frost action under a former periglacial climate. In agreeing 
with Bryan (1928, p. 163), he felt that the Pacific Northwest, during the glacial maximum, experienced a much colder climate than now prevails. Therefore, frozen ground persisted for a longer portion of the year and extended to a greater depth. He pointed out that permafrost may have developed, although he believed the "impermeable and ill-drained, weathered basalt bedrock" would have had the same effect in restricting subdrainage, thus providing a more conducive environment for severe frost action (Kaatz 1959, pp. 152-153). Kaatz speculated that the extent of frost penetration was about $2 \mathrm{~m}$, since mounds did not develop where the soil mantle exceeded that depth. He maintained that the presence of vigorous frost action was strongly supported by the sorted stone patterns which are so prevalent throughout this region, and that these features originated in much the same manner already discussed under the frost-push and frost-pull mechanisms (Kaatz 1959, pp. 154155). Furthermore, he contended that the sorted forms developed after the mounds, and that the intermound areas were subjected to intensive frost action subsequent to the mound formation. The stone stripes continued to form after the majority of the other sorted ground features ceased to be active. Finally, he asserted that all these sorted ground patterns are inactive today, citing their subangular, 1ichen-covered surfaces, discolored and weathered from long exposure to the elements, as evidence. He also mentioned that some solifluction and frost action is presently taking place, but that it is on a much reduced scale from that responsible for the mounds and their associated patterned ground features. 
In 1962, Brunnschweiler presented evidence for a periglacial zone in North America during the Wisconsin stage of glaciation. A major portion of his paper was devoted to a discussion of several columbia Basin surface forms, which he maintained were the resuit of formerly intensive frost action and solifluction. The description of sorted patterns paralleled that of Kaatz (they did field work in central Washington together), although Brunnschweiler (1962, pp. 18-19) believed the mounds and stone structures developed simultaneously, whereas Kaatz (1959, p. 154) postulated that the mounds predated the sorted patterns. Brunnschweiler (1962, p. 18) also suggested that permafrost, with an active layer of about 1.5 to $2 \mathrm{~m}$, existed. He pointed out that, whereever the soil mantle exceeds a thickness of $2 \mathrm{~m}$, solifluction features were not clearly delineated or absent, and in the thicker loess regions, as in southeastern Washington, no evidence of frost action had been found. He agreed with Kaatz in stating that severe frost action and solifluction were enhanced where subsurface drainage was restricted by the frozen and impermeable basalt bedrock.

A detailed analysis of mounds and sorted ground features analogous to those found in north central Oregon and central Washington was provided by Malde $(1961,1964)$ for the western Snake River Plain (Fig. 1). He pointed out that these forms occurred on a variety of parent materials, such as lake beds and welded tuff, although most typically on gravel fans and basaltic lava flows (Malde 1961, B-170). But, here again, the author did not specify which features were found on which type of material; however, he did say that all of these surfaces were of middle Pleistocene or older age. He regarded them as 
relic landforms since patterned ground was not developed on 1ithologically similar younger deposits in the same area.

The characteristics of the sorted features in the western Snake River Plain are comparable to those already discussed for north central Oregon and central Washington. The intermound areas, or stone pavements, normally consist of well-sorted angular stones which range from cobbles to sma11 boulders. Tabular fragments are usually turned on edge and oriented paralle1 to the borders of the pavement, so as to fit tight1y together in the least amount of space (Malde 1961, pp. B-170-171). Smaller, less wel1-sorted, and randomly arranged stones are found below the pavement layer. On slopes of less than one degree, the intermound stone pavements form rectangular and polygonal networks. Striped patterns on slopes, according to Malde (1964, p. 198), resulted from the progressive distortion of sorted nets on level terrain. Stone stripes become obvious as the gradient reaches five degrees and are still noticeabie as the slope increases to about $26^{\circ}$; however, steeper gradients generaliy do not have recognizable stripes. In agreeing with Kaatz (1959, p. 150), Malde (1964, p. 198) mentioned that the varying appearance of the sorted pattems can be described as a continuous succession related to gradient, although all the forms which rely on slope might not be developed at a single locality.

Because of their similarity in arrangenent and structure to cold climate sorted patterned ground, Malde (1964, pp. 200-201) hypothesized that Idaho's western Snake River Plain ground patterns represented a relic landscape that could only be adequately explained through a former periglacial climate. Even though some of the more salient characteristics 
of these features have been modified by recent geomorphic processes, such as wind transport and running water, Malde believed that the intense frost action and solifluction evidence from a past periglacial regime was too strong to ignore.

Fryxe11 (1964), in agreeing with Kaatz and Malde, indicated that Columbia Basin mounds, and their associated sorted ground features, developed under Pleistocene periglacial climatic conditions. The time of mound formation was during the late Wisconsin glaciation. This conclusion was strongly supported by physiographic, stratigraphic, paleontologic, and pedologic evidence. Radiocarbon dating places the maximum interval during which the youngest mounds developed between 14,000 and 7,500 years ago. Fryxe11 emphasized that these limiting dates did not necessarily apply to other patterned ground features, suggesting that stone stripes had been reactivated at least twice in the past 4,000 years. He also mentioned that freshly overturned rock fragments and partially buried shrubs showed some stripes to be active now (Fryxe11 1964, p. 13).

In discussing the mounds and sorted ground pattems of southern Idaho, Fosberg (1965) attributed the formation of drainageways, which separate the mounds, to destructional erosion by solifluction during a former periglacial climate. Stone pavements exhibited the same characteristics as the intermound areas described by Kaatz (1959) and Malde (1961, 1964). Fosberg (1965, p. 33) hypothesized that contraction cracks or frost wedges determined the positions of these ground patterns and he suggested that the evidence indicated that these features may have formed prior to the development and degradation of the mounds. 
CHAPTER IV

\section{METHODOLOGY}

The collection of pertinent information for a number of individual sorted stripes in selected locations throughout the study area was standardized through a check list (Appendix). The check list was developed on the basis of field reconnaissance and the literature review. It facilitated the consistent collection of detailed information on the structure, composition, and occurrence of stone stripes for later analysis. Slope, stripe, and rock orientation measurements were taken with a Brunton Pocket Transit. An Abney Hand Level was used to determine slope angle. Stripe and interstripe dimensions were measured with a 30 m steel tape and a $2 \mathrm{~m}$ steel hand tape. Rock size measurements were conducted with a $30 \mathrm{~cm}$ clear plastic ruler.

A vertical cross section was excavated at the head (top third), center (center third), and toe (lowest third) of each stone stripe investigated. The orientation of the long axes was determined for fifty contiguous surface rocks before beginning the cross sectional excavations because rocks in active stone stripes 1ie mainly with their long axes in the direction of movement, or downslope, and orientation studies can provide an indication of activity and formational processes (Lundqvist 1949). Fifty adjacent rocks were measured for the length of their long axes at the surface, middle, and base of every cross section to determine the extent of vertical sorting (Fig. 10). 


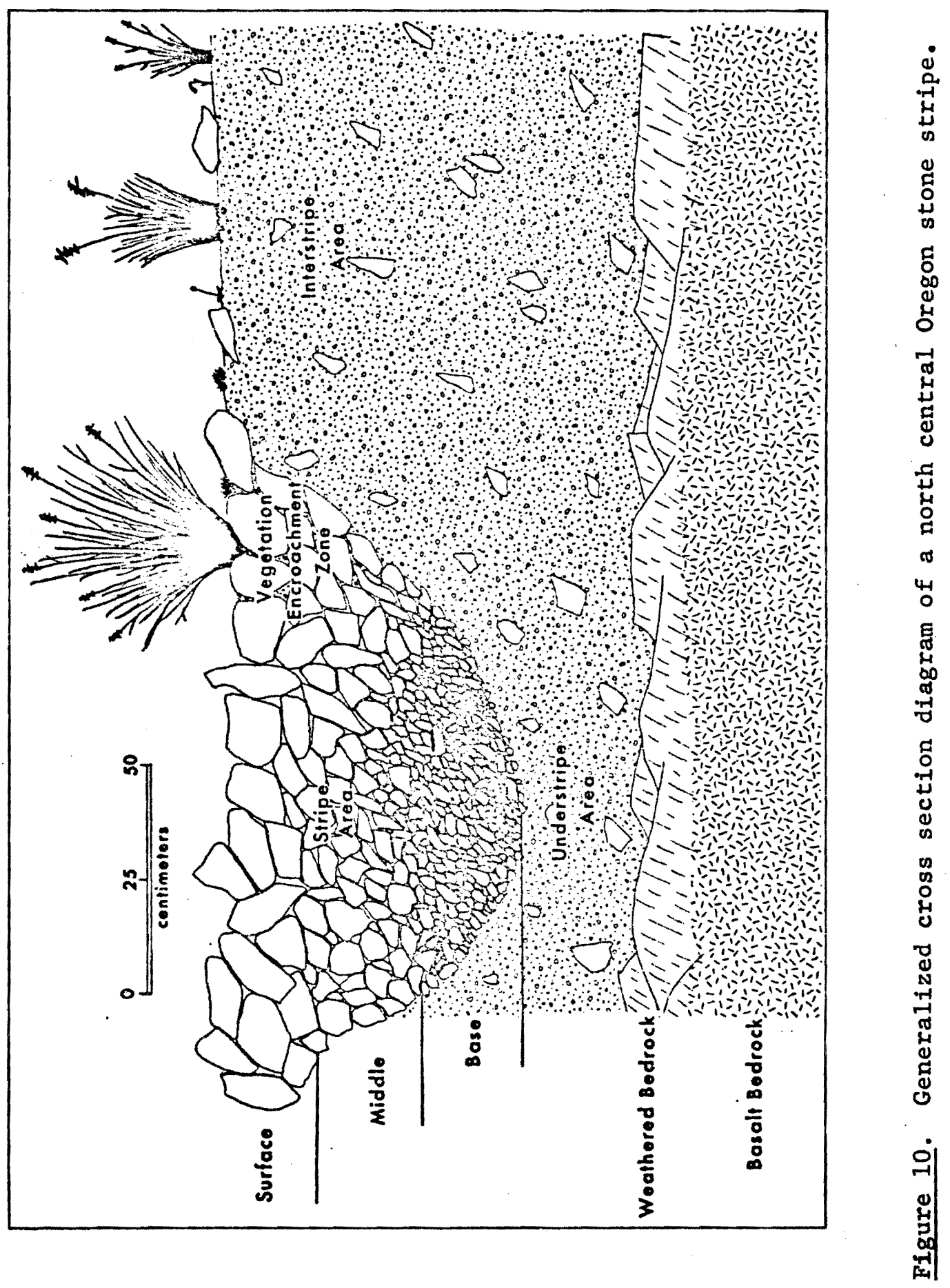


Measurements and sketches of each stone stripe and cross section were recorded as part of the check 1ist. Important descriptive and locational information was also included (Appendix). Information from aerial photographs, soil surveys, topographic maps, and other field Investigations was combined to gain a more encompassing understanding of stone stripe occurrence throughout the Deschutes-Umatilla Plateau. Painted rock measurements were established in several locations to obtain infornation on rates of mass wasting. The method followed was to select rocks in situ in the stripe and interstripe areas for measurement. These rocks were painted, leaving enough space to mark a smal1 " $x$ ". A permanent reference point was established at each site by chiseling an " $\mathrm{X}$ " into bedrock and measurements were made from center of " $\mathrm{x}$ " to center of " $\mathrm{X}$ " (Price and Alexander 1971). The sites were measured with the same steel tape on July 10, 1970; July 8, 1971; and November 24,1972 , so 2 years of data are available. 


\section{CHAPTER V}

\section{ANALYSIS OF STONE STRIPES}

Six study sites with well developed stone stripes were chosen in the thesis area for detailed analysis (Fig. 11). These are at higher elevations which occur primarily along the southern edge of the Deschutes-Umatilla Plateau (Figs. 2 \& 11). An in-depth analysis of a single stone stripe was performed at each site. Information on the general environmental characteristics was also gathered.

\section{INDIVIDUAL STRIPE DESCRIPTIONS}

Study Site Number One

The first site was located along Butler Canyon where U. S. Highway 197 passed over a faulted anticline called Tygh Ridge (Fig. 11). Numerous stone stripes are found throughout this region, especially in the smaller ravines that feed into Butler Canyon. Two stone stripes were investigated in detail at this site and several others were observed for general information.

Stone stripe number one was situated on the lower, relatively straight portion of a $31^{\circ}$ convex slope that faced $N 81^{\circ} \mathrm{E}$ (Fig. 12). The stripe was $38 \mathrm{~m}$ long and varied in width from 0.5 to $2 \mathrm{~m}$. The sorted stripe was oriented $\mathrm{N} 88^{\circ} \mathrm{E}$ and extended straight downslope. There was a shallow depression in the slope that appeared to cause the stripe to widen about halfway down its length where it passed over the low point; 


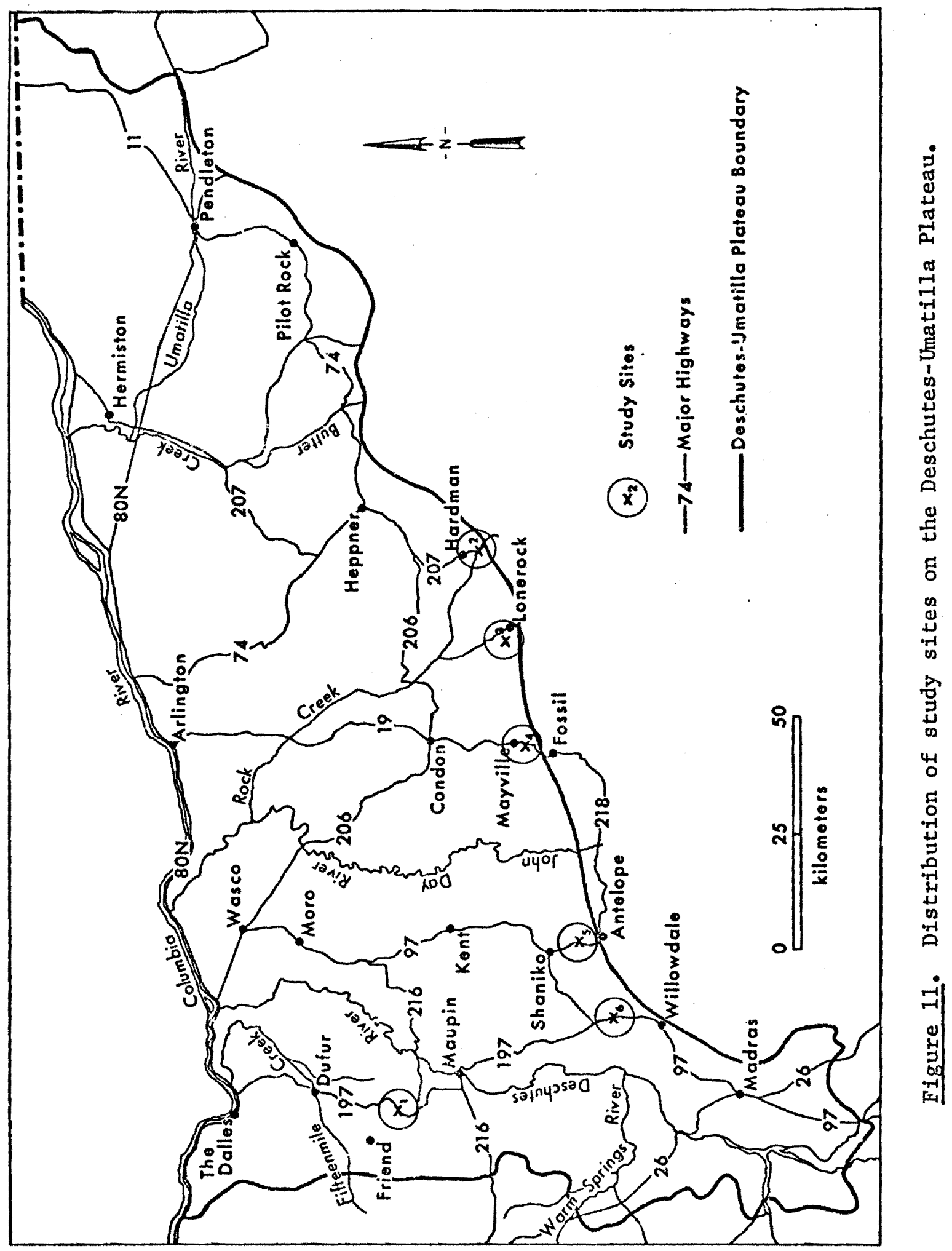




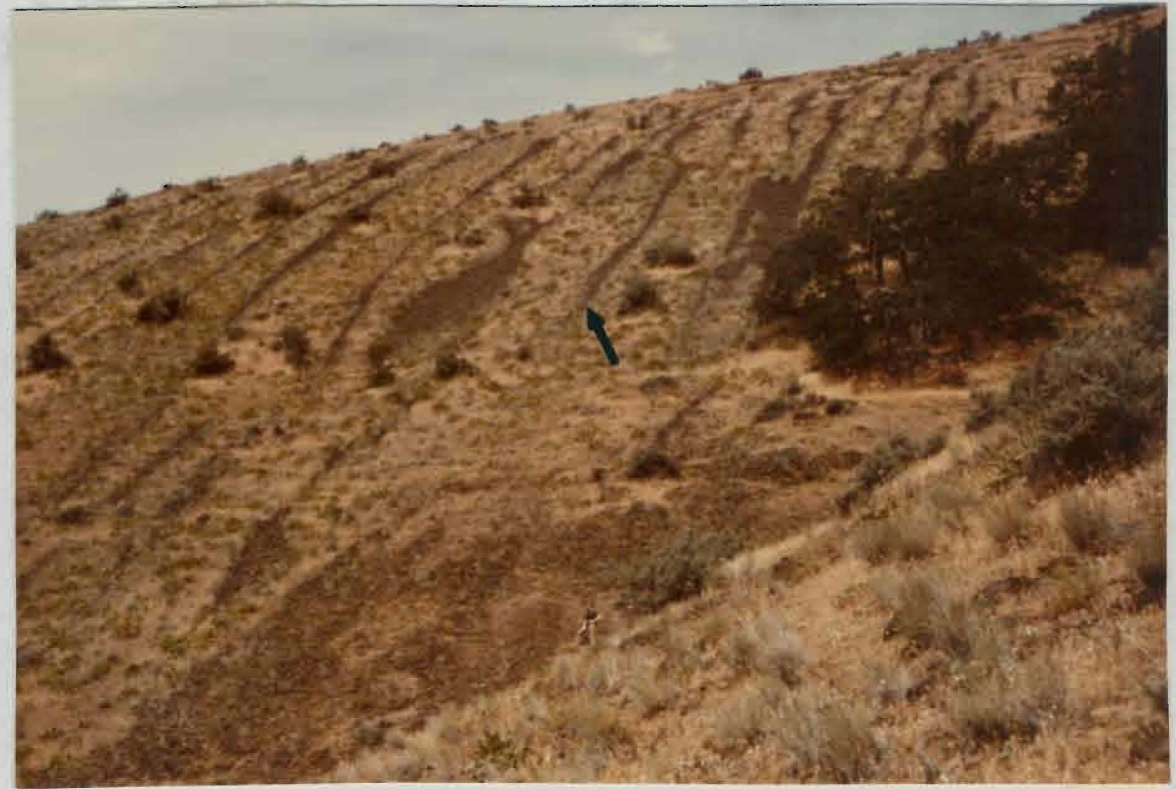

Figure 12. Stone stripe number one, located in Butler Canyon, Tygh Ridge, is $38 \mathrm{~m}$ long and averages about $1 \mathrm{~m}$ wide. The slope angle is $31^{\circ}$ and the stripe orientation is $N 88^{\circ} \mathrm{E}$.

however, a much greater widening of the stripe occurred at its head and toe (Fig. 12). Vegetation encroachment was extensive along the margins of the entire stripe and was particularly evident over much of the stripe's lower section.

The interstripe area varied from 4 to $6.5 \mathrm{~m}$ in width, averaging $5.5 \mathrm{~m}$. The interstripe area increased in depth from $75 \mathrm{~cm}$ near the head of the stripe to over $85 \mathrm{~cm}$ adjacent to the toe, and was composed of very stony silt to silt loam. There was an accumulation of rock debris on the surface of the interstripe area, as well as upheaved and overturned rocks, small circles of bare and upturned soil, and uprooted vegetation. 
Stripe number one was composed of fine-grained, dark-gray basalt fragments. Lichen growth was well developed on the rocks, contributing to their dark color. Surface rock orientation studies did not reveal any strong alignment of the long axes, although there was some correlation with stripe and slope direction (Fig. 13).

The stripe's depth decreased downslope from $56 \mathrm{~cm}$ at the head, to $44 \mathrm{~cm}$ at the center, to $30 \mathrm{~cm}$ at the toe (Fig. 14A). The thickness of soil beneath the stripe increased downslope from $15 \mathrm{~cm}$ at the head, to $26 \mathrm{~cm}$ at the center, to over $55 \mathrm{~cm}$ at the toe (Fig. 14A). The surface of the bedrock below the stripe was jagged and uneven, with weathered bedrock resting on top of the consolidated basement material. The bedrock underneath the interstripe area exhibited the same characteristics.

In vertical cross section, the stripe narrowed with depth, and displayed strong vertical sorting. Mean rock sizes from surface, to middle, to base were $11.5 \mathrm{~cm}$, to $8.6 \mathrm{~cm}$, to $5.1 \mathrm{~cm}$, respectively. While the mean rock size for the surface and middle zones decreased from head to toe, the average rock size along the base of the stripe increased from head to toe (Fig. 15). The standard deviations of the rock size measurements also decreased with depth into the stripe (Fig. 15).

The stripe and interstripe surfaces were fairly level in the head and center cross sections, but in the toe cross section, the stripe protruded, in convex fashion, slightly higher than the bordering interstripe soil (Fig. 14A). The rocks at the base of the stripe were caked with fine soil and the stones at the margins of the stripe were covered with vegetation, soil, and roots. 


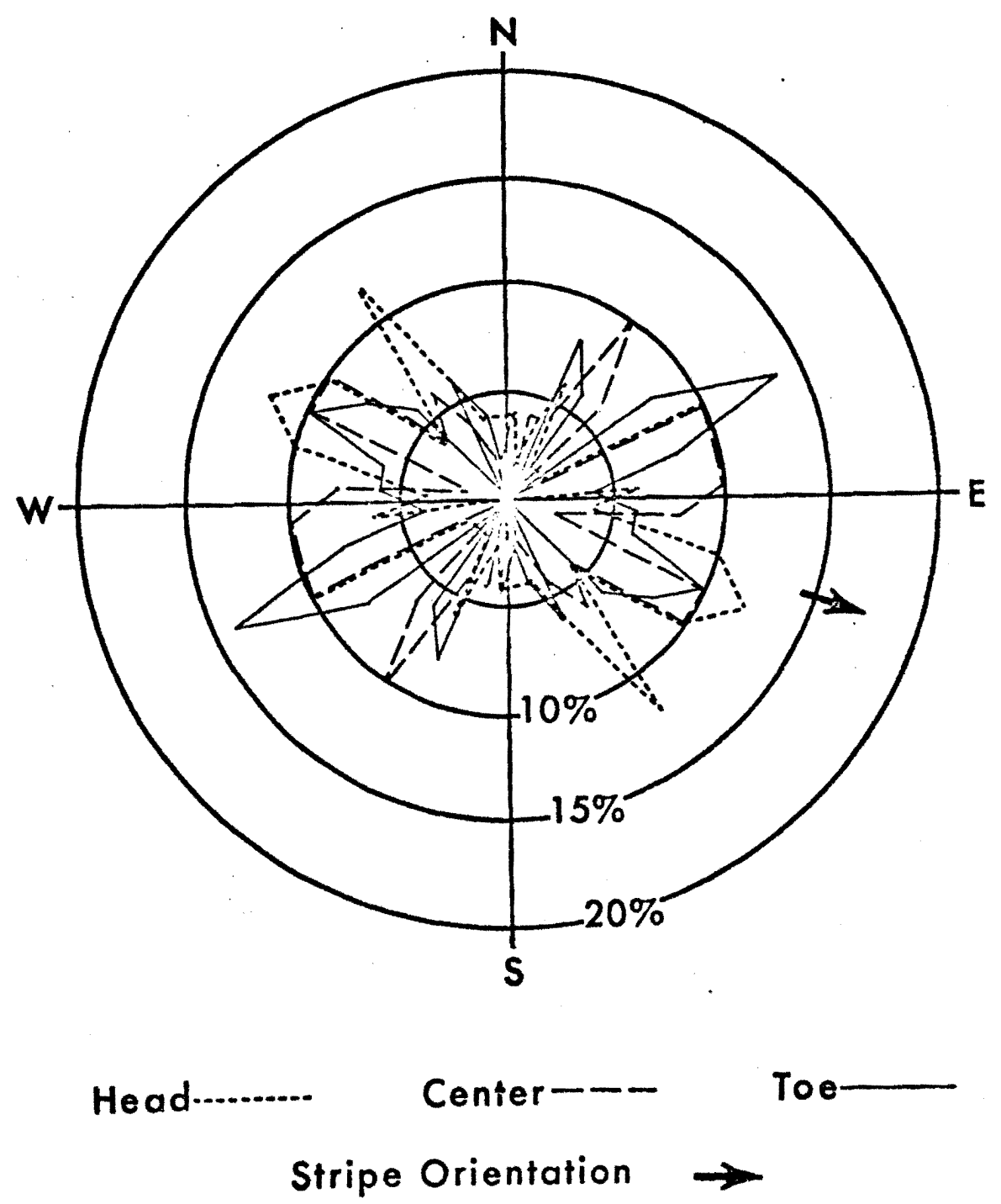

Figure 13. Surface rock orientation diagram for stripe number one. 


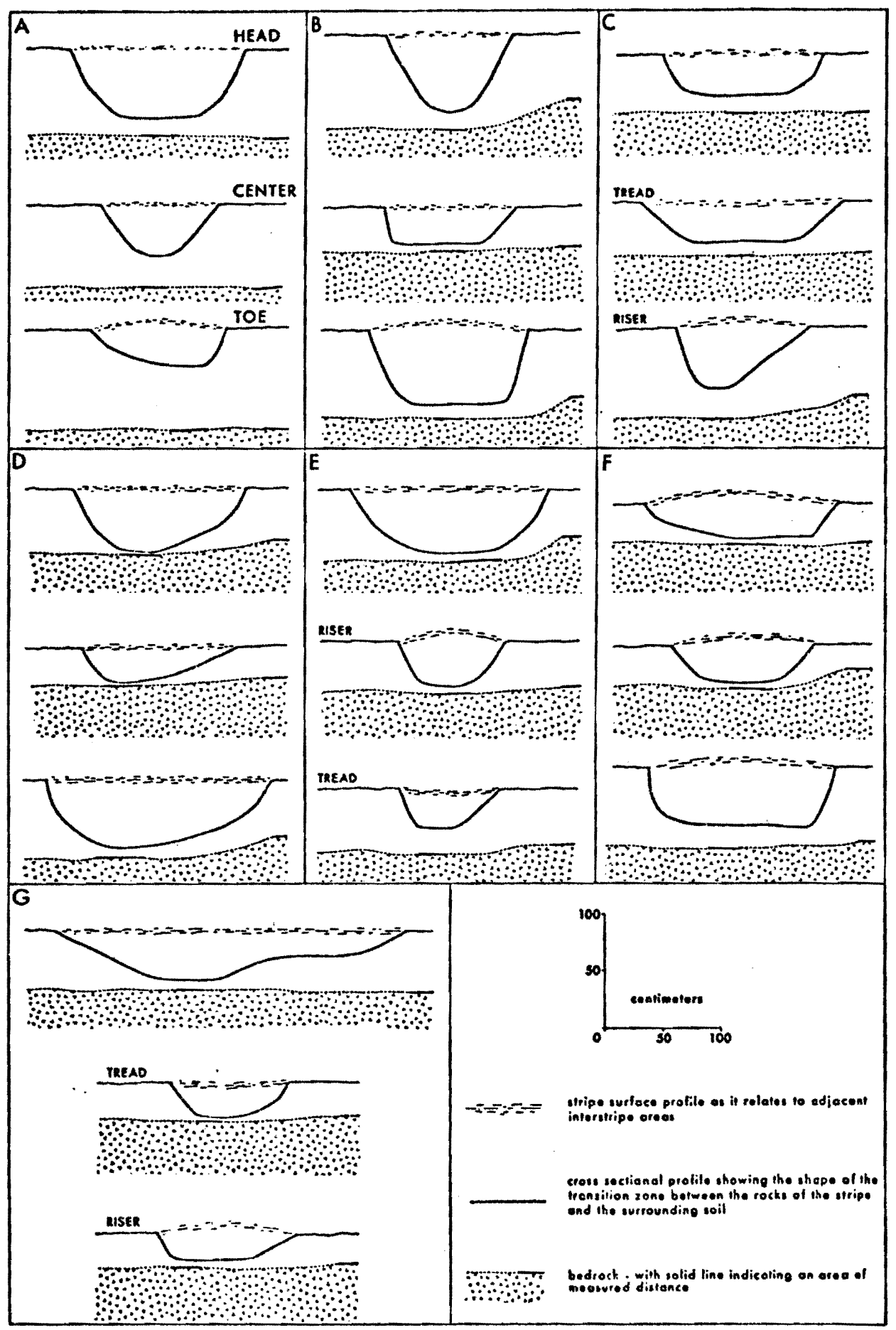

Figure 14. Composite diagram of stone stripe cross sectional profiles. 


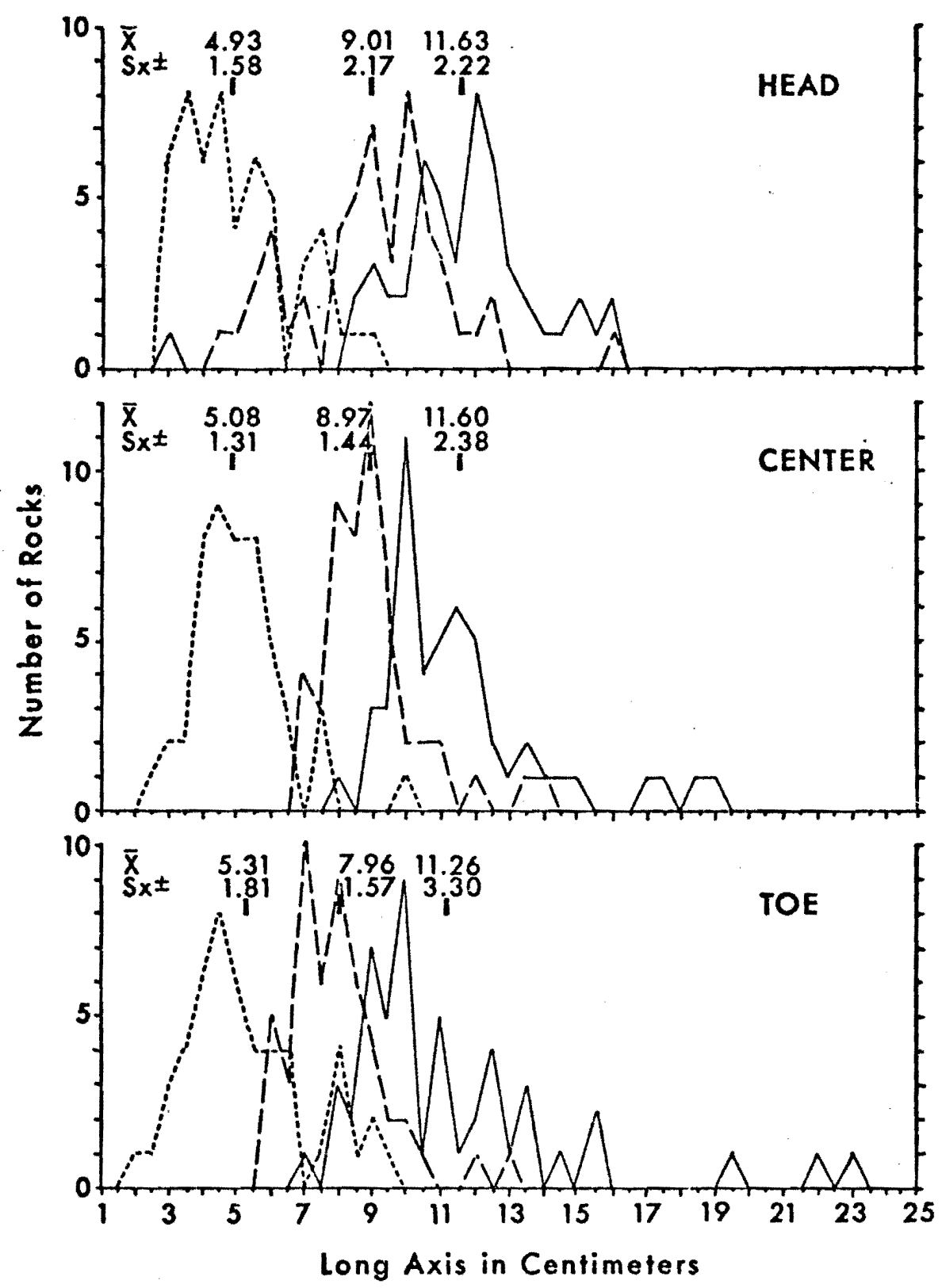

Base....... Middle-- - Surface-

Figure 15. Rock size measurements for head, center, and toe cross sections for stripe number one. 
Upslope from stripe number one there were greater numbers of sorted stripes spaced closer together (Fig. 12). Bedrock outcrops were located just above this zone of stripes. Mounds occurred on top of the slope with related patterned ground, but there was no direct connection between this patterned ground and the stripes farther downslope. Tongues of soil often extend downslope between the stripes, however. Other stripes on this slope had large concentrations of rock material and appeared almost like former talus slopes with vegetation covering the rock debris (Fig. 12). However, excavations in the interstripe areas revealed fine silty soil with essentially no rock material. Terracettes, which crossed the stripes, were also observed and will be discussed later.

Stone stripe number two also was located in the Butler Canyon area and extended for $92 \mathrm{~m}$ down the middle and lower portion of a convex slope that had an overall gradient of about $28.5^{\circ}$ (Fib. 16). Both the slope and the head of the stripe had an orientation of $\mathrm{S} 75 \% \mathrm{~W}$. The toe of the stripe, however, shifted to a more westerly direction of $582^{\circ} \mathrm{W}$ in orienting itself down the steepest available slope. The stripe's width increased downslope with head and center widths averaging about $0.8 \mathrm{~m}$, while the toe expanded to an average width of $1.2 \mathrm{~m}$. Vegetation encroachment was pronounced along the edges of the entire stripe, and heavy moss and Iichen growth was observed on the stripe's rocks, especially near the head (Fig. 19A).

The interstripe area varied from 2 to $9.6 \mathrm{~m}$ in width, and averaged about $3 \mathrm{~m}$. It was composed of very stony silt to silt loam, and fluctuated in depth from $55 \mathrm{~cm}$ at the head, to $35 \mathrm{~cm}$ in the center, to $56 \mathrm{~cm}$ 
at the toe (Fig. 14B). The interstripe area appeared very unstable, with rocks upheaved, overturned, and concentrated at the soil surface. Vegetation was uprooted and buried. Fine material from the interstripe area appeared to be encroaching on the stripe, filling the voids between the rocks (Fig. 19).

Stripe number two was composed of dark-gray, fine-grained basalt fragments. Surface rock orientation measurements revealed a fairly strong relationship between stripe direction and long axes alignment (Fig. 17). Some of the larger surface rocks seemed to form step-like features periodically throughout the length of the stripe, blocking smaller rocks behind them.

The stripe's depth varied from $62 \mathrm{~cm}$ at the head, to $30 \mathrm{~cm}$ at the center to, $65 \mathrm{~cm}$ at the toe (Figs. 14B \& 19). The soil beneath the

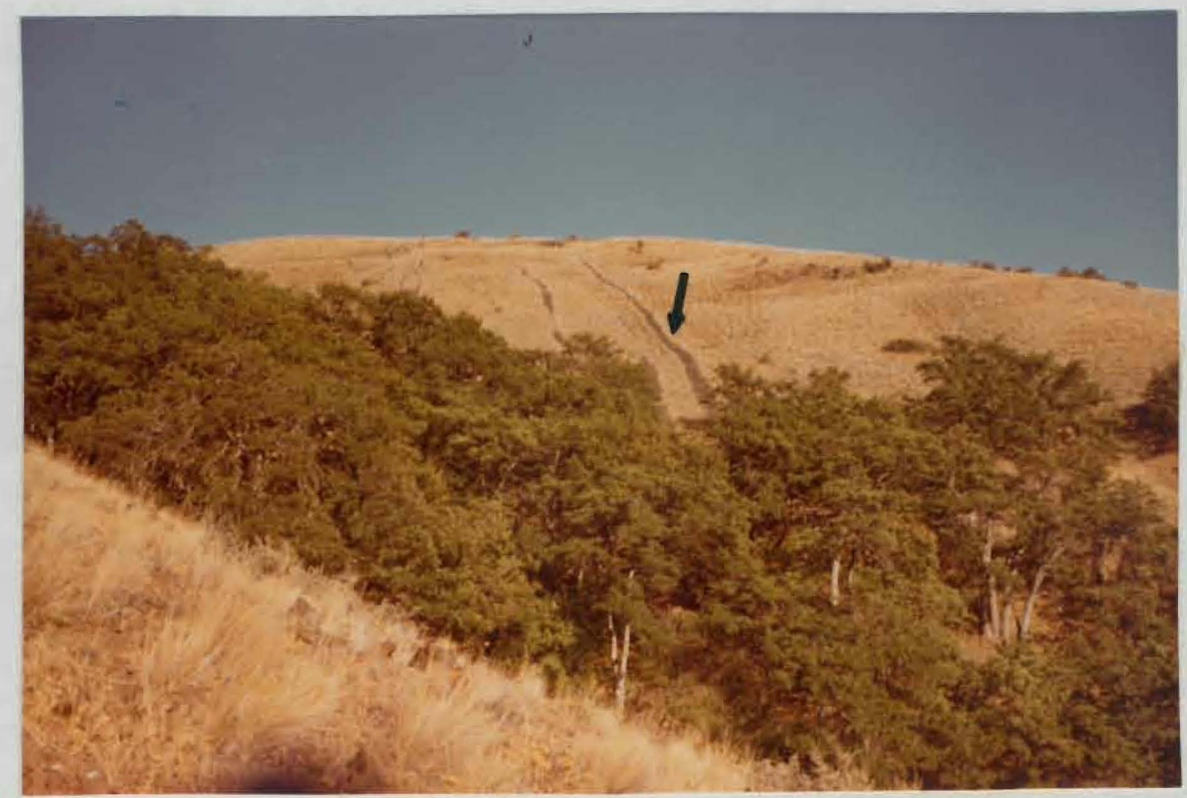

Figure 16. Stone stripe number two, located in Butler Canyon, Tygh Ridge, is $92 \mathrm{~m}$ long and averages about $0.9 \mathrm{~m}$ across. The slope angle is $28.5^{\circ}$ and the stripe orientation is $575^{\circ} \mathrm{W}$ with the lower portion shifting to a $582^{\circ} \mathrm{W}$ direction. 

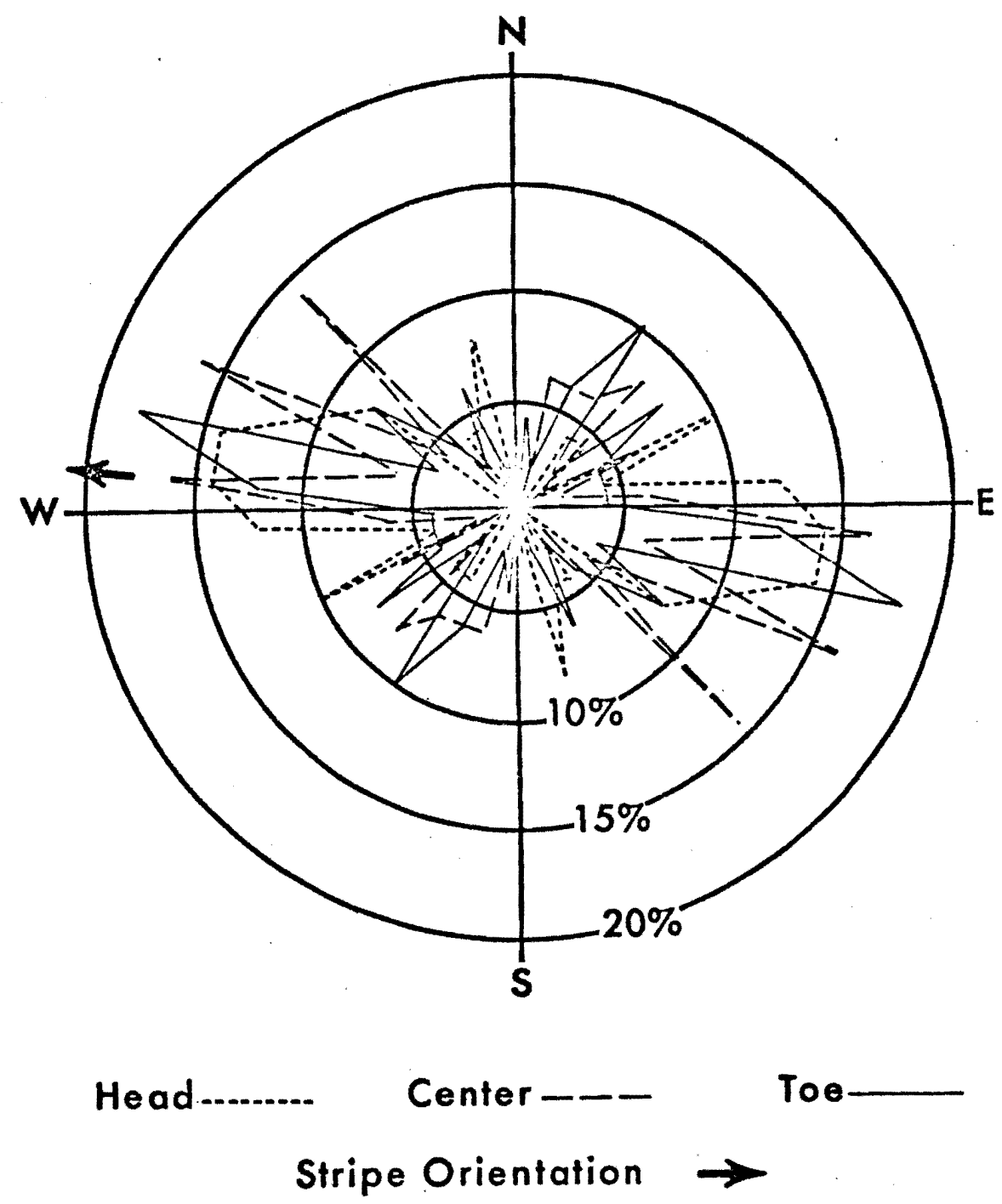

Figure 17. Surface rock orientation diagram for stripe number two. 
stripe ranged in depth from $16 \mathrm{~cm}$ at the head, to $7 \mathrm{~cm}$ at the center, to $10 \mathrm{~cm}$ at the toe (Figs. 14B \& 19). The surface of the bedrock below the stripe was rough and uneven with some in situ weathered material resting on top of the coherent bedrock. The bedrock underlying the interstripe area displayed the same attributes.

This stripe exhibited strong vertical sorting in cross section. Mean rock sizes for the stripe were $15.8 \mathrm{~cm}$ at the surface, $10.2 \mathrm{~cm}$ in the middle zone, and $6.0 \mathrm{~cm}$ along the base of the stripe. Average surface rock size increased downslope, so that the largest rocks were concentrated at the surface of the toe (Fig. 18). Rocks of the middle zone did not show any consistent pattern along the stripe's length. Base rocks, on the average, decreased in size downslope (Fig. 18). Standard deviations became greater downslope in the surface and middle zones, while the base rocks became slightly more homogeneous, On the average, standard deviations became less with depth into the stripe at each cross section (Fig. 18).

Stripe number two was slightly convex in the toe cross section, but remained relatively level with the adjacent soil, in the head and center cross sections (Fig. 14B). The rocks at the margins of the stripe were covered with soil and vegetal matter. Stones along the edges and base of the stripe were covered with fine soil (Fig. 19). Bedrock outcrops occurred throughout the slope. Vegetation was well developed on the entire hillside, and was beginning to cover all the stripes (Fig. 16). 


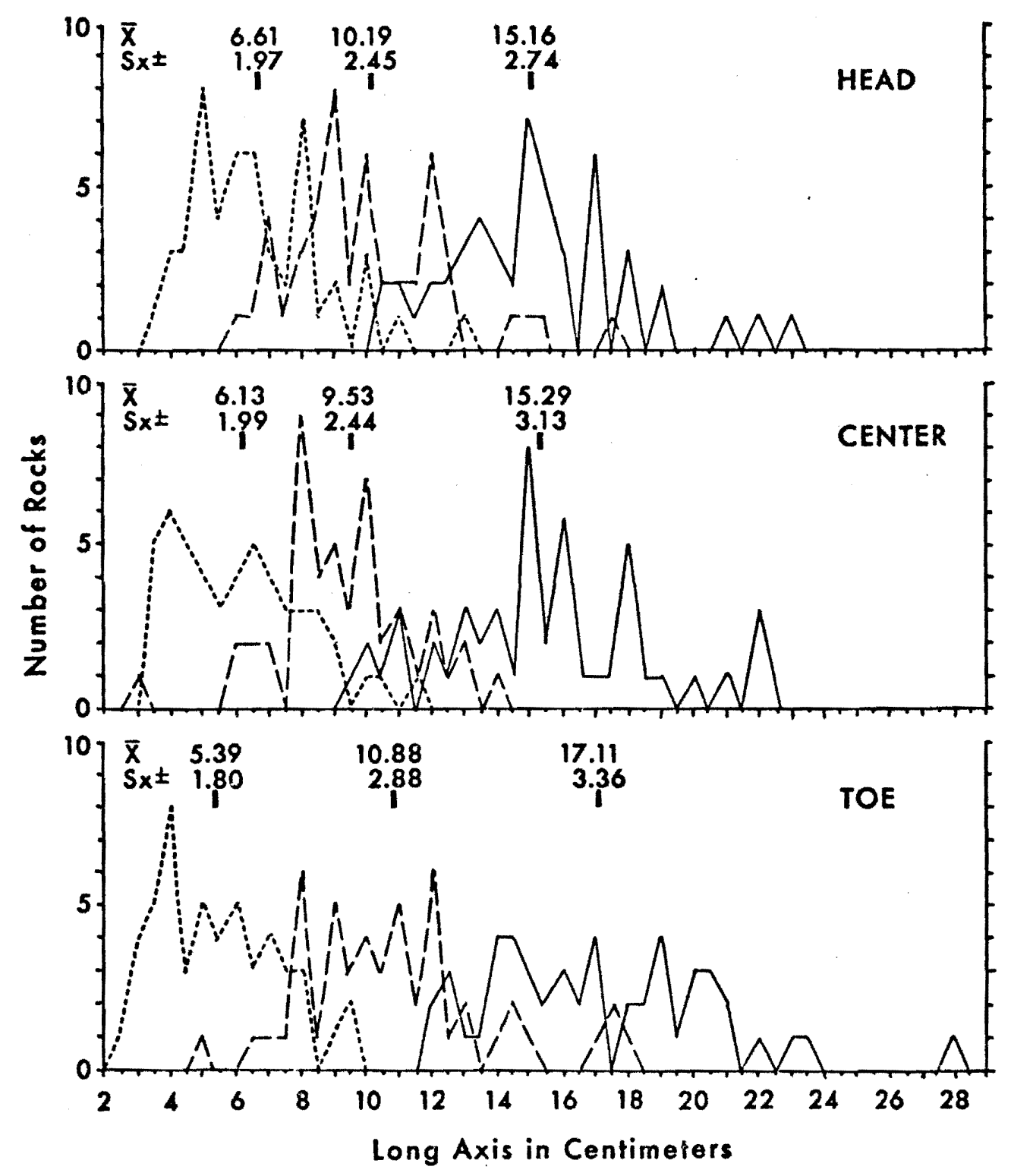

Base-....... Middle-_- Surface-

Figure 18. Rock size measurements for head, center, and toe cross sections for stripe number two. 

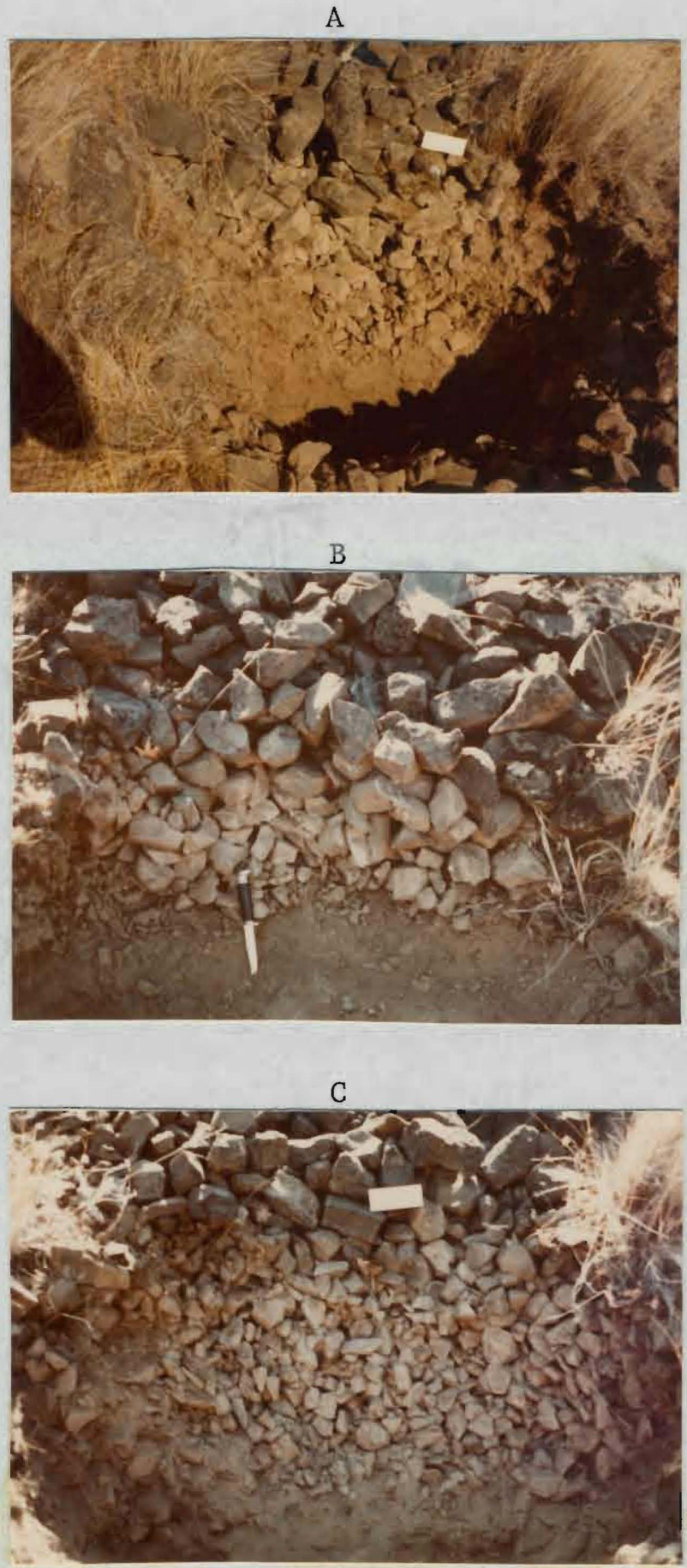

Figure 19. Head (A), center (B), and toe (C) cross sections of stripe number two. 
Study Site Number Two

The second study site was located south of Hardman, where State Highway 207 runs along Rock Creek (Fig. 11). Patterned ground and mounds are very abundant in this region and many excellent examples occur throughout the area. One stone stripe was investigated in detail at this research site.

Stone stripe number three was situated on the lower, relatively straight, portion of a $28^{\circ}$ convex slope that faced S23\% (Fig. 20). The stripe was $52.6 \mathrm{~m}$ 1ong, and narrowed in width downslope from $2 \mathrm{~m}$ at the head and center to about $1 \mathrm{~m}$ at the toe. Oriented $\mathrm{s} 21^{\circ} \mathrm{W}$, the stripe extended over a slight depression in the side of the hill, where vegetation was better developed (Fig. 20). Vegetation encroachment was extensive along the edges of the entire stripe, particularly where terracettes crossed the stripe (Fig. 21).

The interstripe area was composed of stony silt to silt loam, and varied from 3.3 to $9.5 \mathrm{~m}$ in width, averaging about $6 \mathrm{~m}$. The soil in the interstripe area ranged in depth from $48 \mathrm{~cm}$ at the head, to $44 \mathrm{~cm}$ at the center, and increased to $58 \mathrm{~cm}$ at the toe (Fig. 14C). Overturned and upheaved rocks, buried vegetation, signs of use by cattle, and a prevalence of stones at the ground's surface provided ample evidence of instability in the interstripe area.

Stripe number three was composed of fine-grained, dark-gray to light-brown basalt rocks, with some intervening vesicular fragments found throughout the stripe (Fig. 21). Several rocks were on edge, especially at the lower end of the stripe. Larger rocks appeared to be 


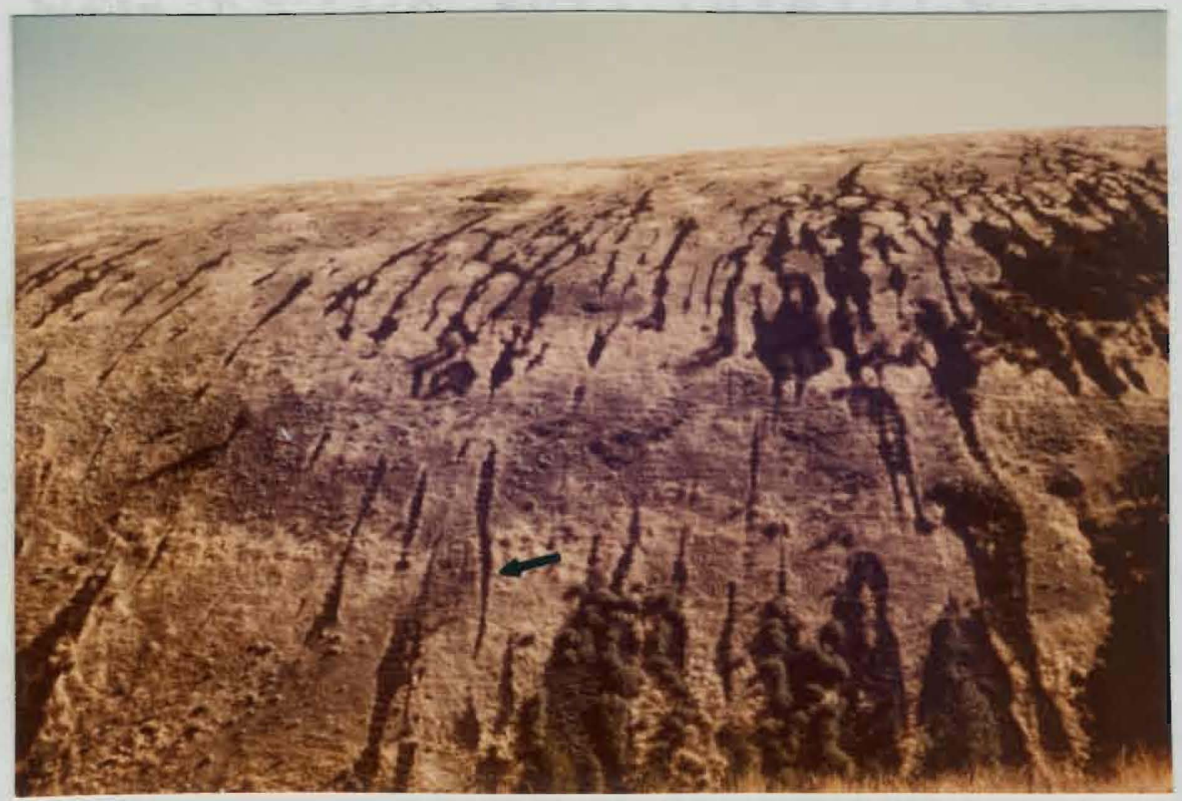

Figure 20. Stone stripe number three, located south of Hardman, is $52.6 \mathrm{~m}$ long and averages about $1.5 \mathrm{~m}$ wide. The slope has a gradient of $28^{\circ}$ and is oriented $523^{\circ} \mathrm{W}$.

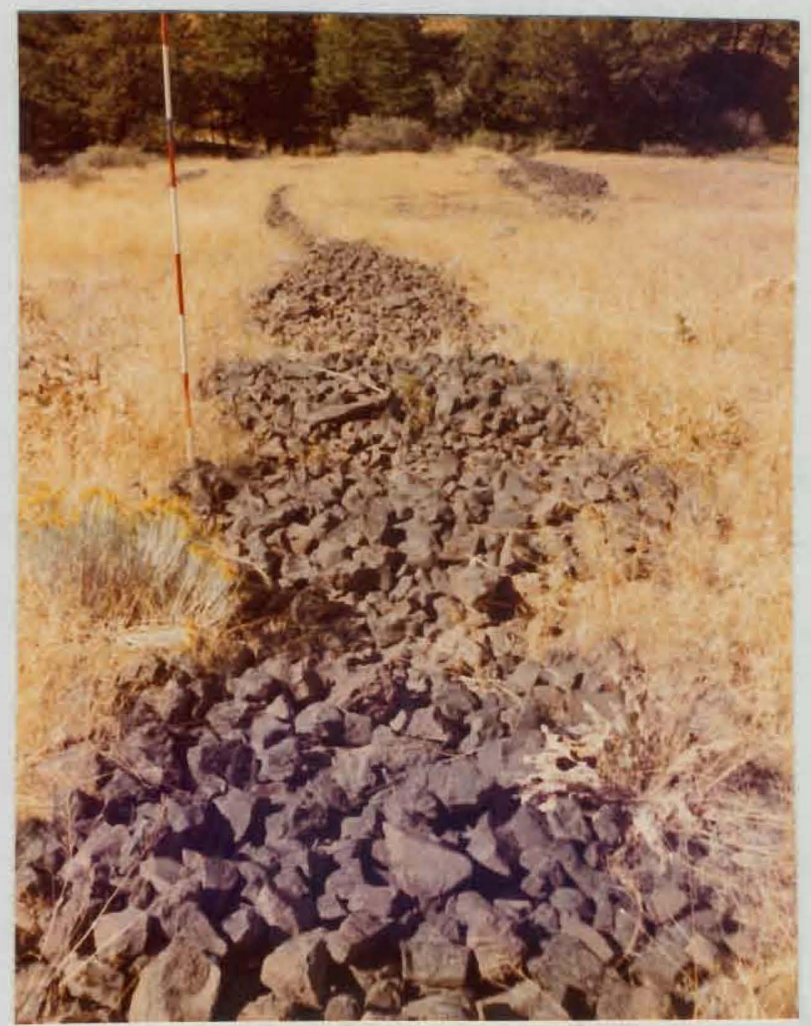

Figure 21. Vegetation encroachment and terracettes on stripe number three. The pole is divided into $30 \mathrm{~cm}$ sections. 
scattered throughout the entire stripe with no noticeable periodicity. Surface rock orientation studies revealed a very strong alignment of the long axes in the direction of the stripe and slope (Fig. 22). In fact, the orientation becomes stronger downslope from the head, to center, to the toe (Fig. 22).

The stripe's depth increased downslope from $33 \mathrm{~cm}$ at the head, to $34 \mathrm{~cm}$ at the center, to $50 \mathrm{~cm}$ at the toe (Fig. 14C). The depth of the soil beneath the stripe was $14 \mathrm{~cm}$ at the head and $12 \mathrm{~cm}$ at the center, and increased to $28 \mathrm{~cm}$ at the toe (Fig. 14C). The soil under the stripe appeared to contain more moisture than the soil in the adjacent interstripe areas at the same depth. The surface of the bedrock below the stripe was uneven and weathered. The bedrock underneath the interstripe area displayed similar characteristics.

In vertical cross section, stripe number three exhibited vertical, but no horizontal, sorting. Mean rock sizes from surface, to middle, to base were $15.0 \mathrm{~cm}$, to $9.7 \mathrm{~cm}$, to $6.1 \mathrm{~cm}$, respectively. While the mean surface rock size decreased downslope, the average rock size for the middle and base of the stripe varied, showing no identifiable pattern (Fig. 23). The standard deviations of these rock size measurements decreased from the surface to the middle to the base of the stripe on the average (Fig. 23).

Several terracettes crossed this stripe (Figs. $20 \& 21$ ). At each tread, the stripe was relatively level to slightly concave in comparison with the adjacent ground surfaces, while throughout the riser portion of each terracette, the stripe rose convexly above the interstripe surfaces (Figs. 14C \&21). In general, the rocks at the edges 


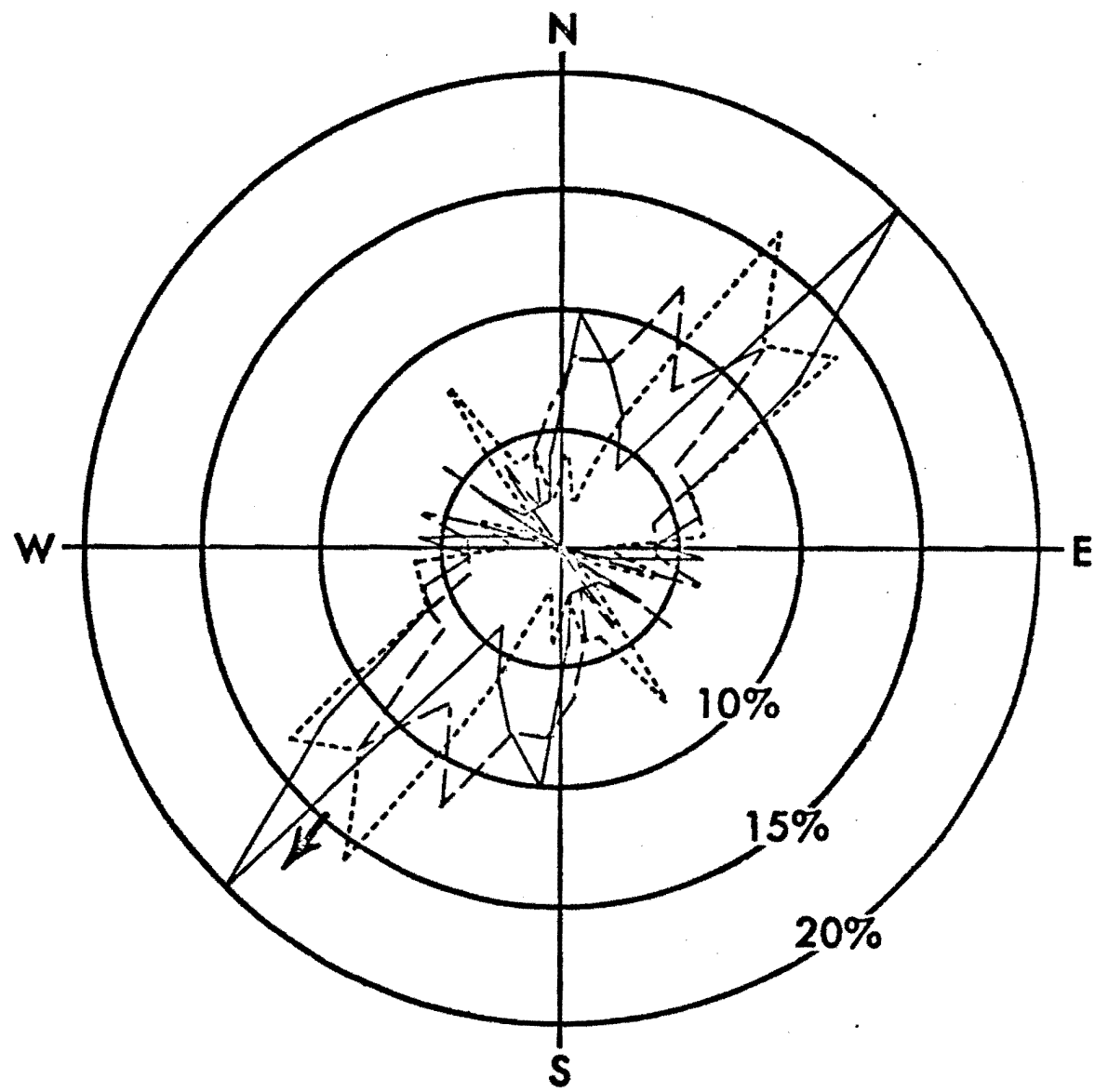

Head.......... Center-- Toe-

Stripe Orientation $\rightarrow$

Figure 22. Surface rock orientation diagram for stripe number three. 

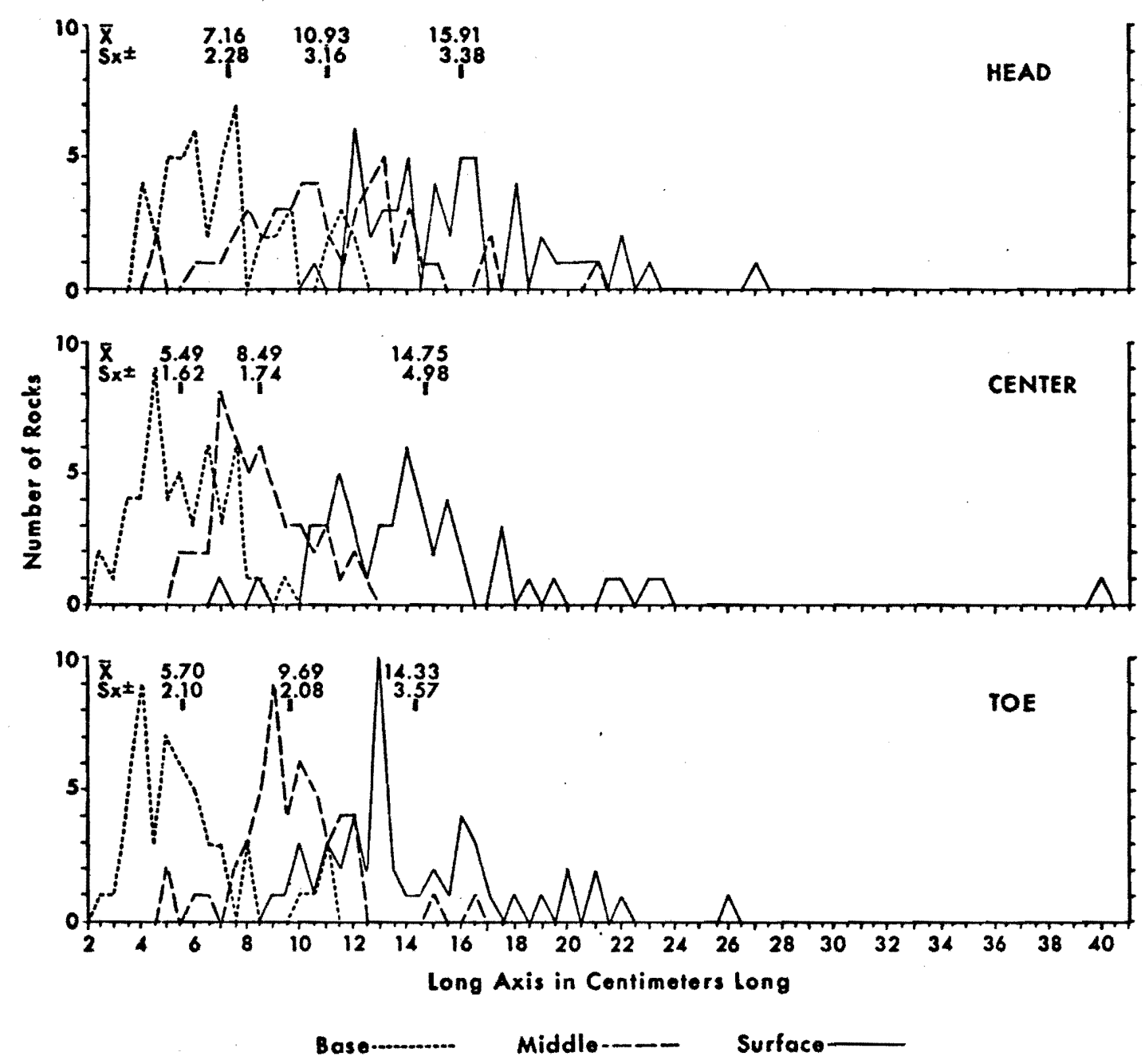

Figure 23. Rock size measurements for head, center, and toe cross sections for stripe number three. 
of the stripe were covered with vegetation and soil; however, several stones were covering vegetation at the margins and at the toe of the stripe. Fine soil covered the rocks at the edges and along the base of the stripe.

Upslope and adjacent to stripe number three there were numerous other stripes (Fig. 20). Here again the slope appears as if it were once a continuous talus slope; however, excavations in the interstripe areas did not reveal any buried rock material. Mounds and patterned ground were abundant along the top of the slope (Fig. 20). Vegetation was better developed at the base of the slope, especially along some of the stripe margins, suggesting better moisture relationships here (Fig. 20)

\section{Study Site Number Three}

The third study site was located a few miles west of the ghost town of Lonerock (Fig. 11). Large-scale stone stripes were we11 developed on most of the slopes in this area. Mounds and patterned ground occurred on the plateau surfaces that surrounded Lonerock. A detailed study of one stripe was carried out at this research site.

Stone stripe number four was located on a hillside that faced $\mathrm{S} 65^{\circ} \mathrm{E}$. The stripe extended over the slightly convex lower portion of the slope, with a gradient of $21^{\circ}$ at the stripe's head, and $28^{\circ}$ at the stripe's toe (Fig. 24). The stripe was $100 \mathrm{~m}$ in length, and varied in width from 1 to $3 \mathrm{~m}$, averaging about $1.5 \mathrm{~m}$. Overa11, stripe number four was oriented approximately $568.5^{\circ} \mathrm{E}$, although it changed to a $N 84^{\circ} \mathrm{E}$ direction for a short distance as it passed over a basalt outcrop near 
the lower end of its head (Fig. 24). The stripe started just below a bedrock outcrop where two short stripes coalesced (Fig. 24). Vegetation encroachment was extensive along the edges of the entire stripe. The stripe, which terminated in a ravine, had rock debris piling up behind and burying the lower limbs of several shrubs located there.

The interstripe area ranged from 2 to $8 \mathrm{~m}$ in width, with an average width of about $4 \mathrm{~m}$. The stony silt to silt loam of the interstripe area fluctuated in depth from $41 \mathrm{~cm}$ near the head of the stripe,

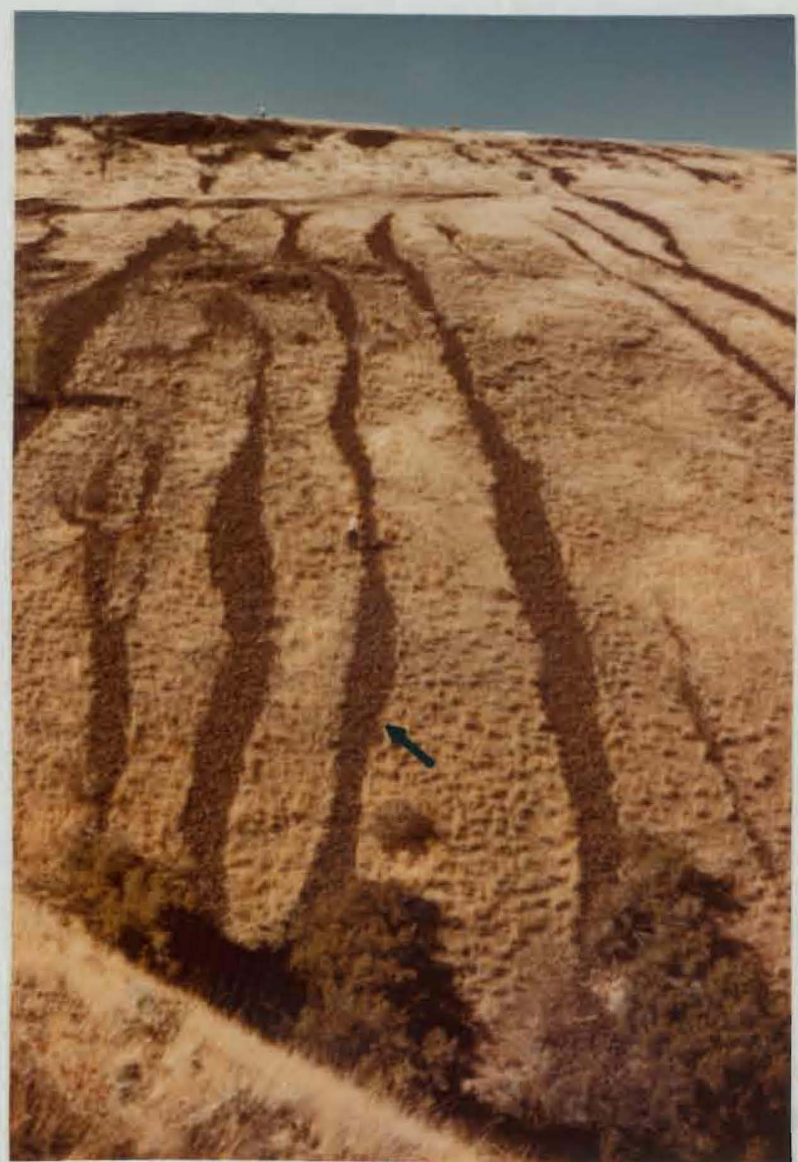

Figure 24. Stone stripe number four, located west of Lonerock, is $100 \mathrm{~m}$ long, and averages about $1.5 \mathrm{~m}$ wide. The slope angle changed from $21^{\circ}$ at the head, to $28^{\circ}$ along the toe, and was oriented $\mathrm{S} 68.5^{\circ} \mathrm{E}$. The two men provide scale. 
to $25 \mathrm{~cm}$ near the center, to $45 \mathrm{~cm}$ opposite the toe of the stripe. There was some concentration of rock debris at the surface of the interstripe area, and evidence of instability was considerable.

Stripe number four was comprised of dark-gray to 1ight-brown basalt fragments. A large number of vesicular rocks were interspersed throughout the length of the stripe. Surface rock orientation measurements revealed a positive correlation with stripe and slope direction (Fig. 25).

The stripe's depth varied downslope from $53 \mathrm{~cm}$ at the head, to $26 \mathrm{~cm}$ at the center, to $56 \mathrm{~cm}$ at the toe (Fig. 14D). The thickness of soil beneath the stripe increased downslope from a barely measureable 3 and $2 \mathrm{~cm}$ at the head and center, respectively, to $9 \mathrm{~cm}$ at the toe (Fig. 14D). The surface of the bedrock below the stripe and interstripe area was jagged and uneven, with a 5 to $10 \mathrm{~cm}$ zone of weathered bedrock.

In vertical cross section, stripe number four displayed strong vertical, but no discernable horizontal, sorting within the stripe itself. Mean rock sizes from surface, to middle, to base were $15.5 \mathrm{~cm}$, to $8.4 \mathrm{~cm}$, to $5.4 \mathrm{~cm}$, respectively. The mean rock size for the surface zone increased from head, to center, to toe (Fig. 26). The average rock size at the stripe's base remained fairly constant (Fig. 26). On the average, the standard deviation of these rock size measurements decreased with depth into the stripe, as well as from the head, to center, to toe (Fig. 26).

The stripe and interstripe surfaces were fairly leve1 throughout the length of the stripe (Fig. 14D). The rocks along the middle and base of the stripe were caked with fine soil. Vegetative matter and 


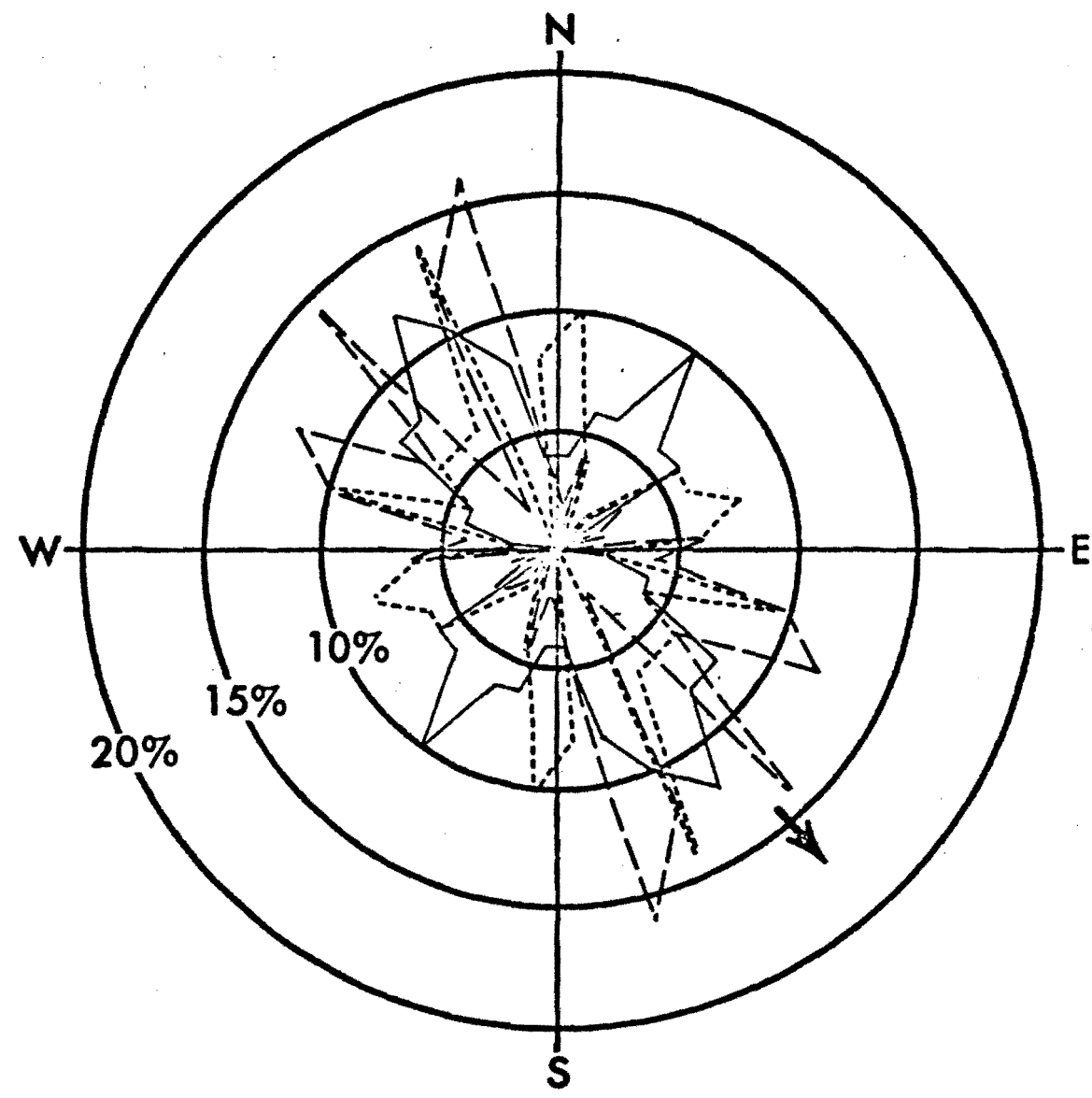

Head.......... Center - - Toe-

\section{Stripe Orientation $\rightarrow$}

Figure 25. Surface rock orientation diagram for stripe number four. 

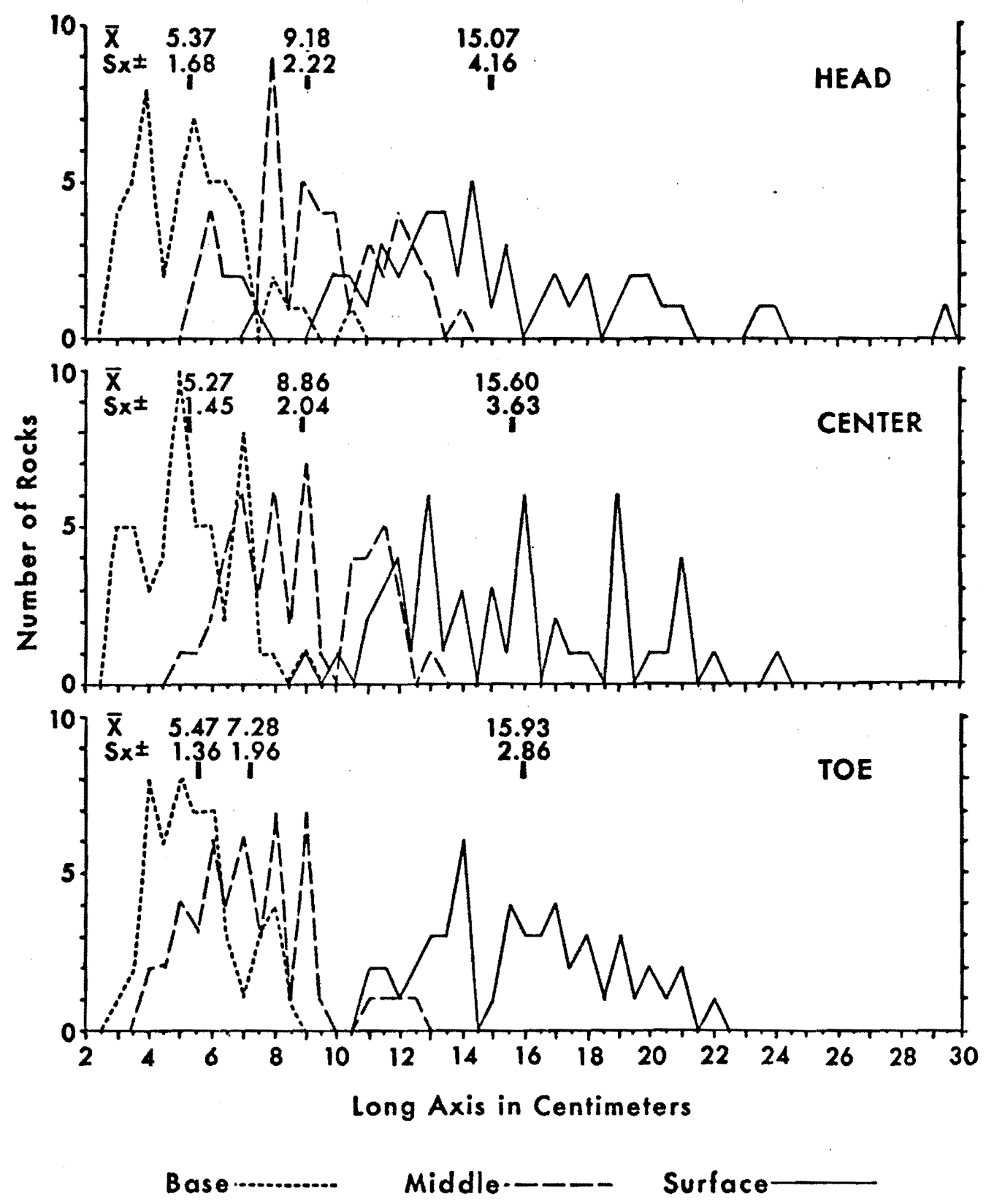

Figure 26. Rock size measurements for head, center, and toe cross sections for stripe number four. 
fine soil covered a substantial portion of the rocks that composed the stripe's margins. There was a dead bush located about halfway down the right side of the stripe. The bush seemed to be retarding stripe movement because there was a piling up of rocks behind it.

Stripe number four was one of a series of long parallel stone stripes that exhibited some sinuousity and seemed to increase in width downslope, or wherever the gradient lessened, such as when the stripes passed over outcrops of basalt (Fig. 24). Bedrock outcrops were located just above, and throughout the upper portions of, this zone of stone stripes. Mounds, and other forms of patterned ground, were situated on the level plateau surface well above the zone of stripes. No direct connection between the two areas was observed. Poorly developed terracettes crossed stripe number four at several locations.

\section{Study Site Number Four}

The fourth study site was located south of Mayville, and north of Fossil, along State Highway 19 (Fig. 11). There are numerous well developed stone stripes that radiate from the summits of this region's rounded hills. Stone stripe number five was located about halfway down one of these convex slopes (Fig. 27). The stripe originated just below a slight depression that separated another zone of stone stripes higher on the slope (Fig. 27). The head and center portions of stripe number five were situated on a $20.5^{\circ}$ slope, and the toe of the stripe was located on a steeper gradient of $25.5^{\circ}$. Both the stripe and the slope were oriented $90^{\circ} \mathrm{E}$. 


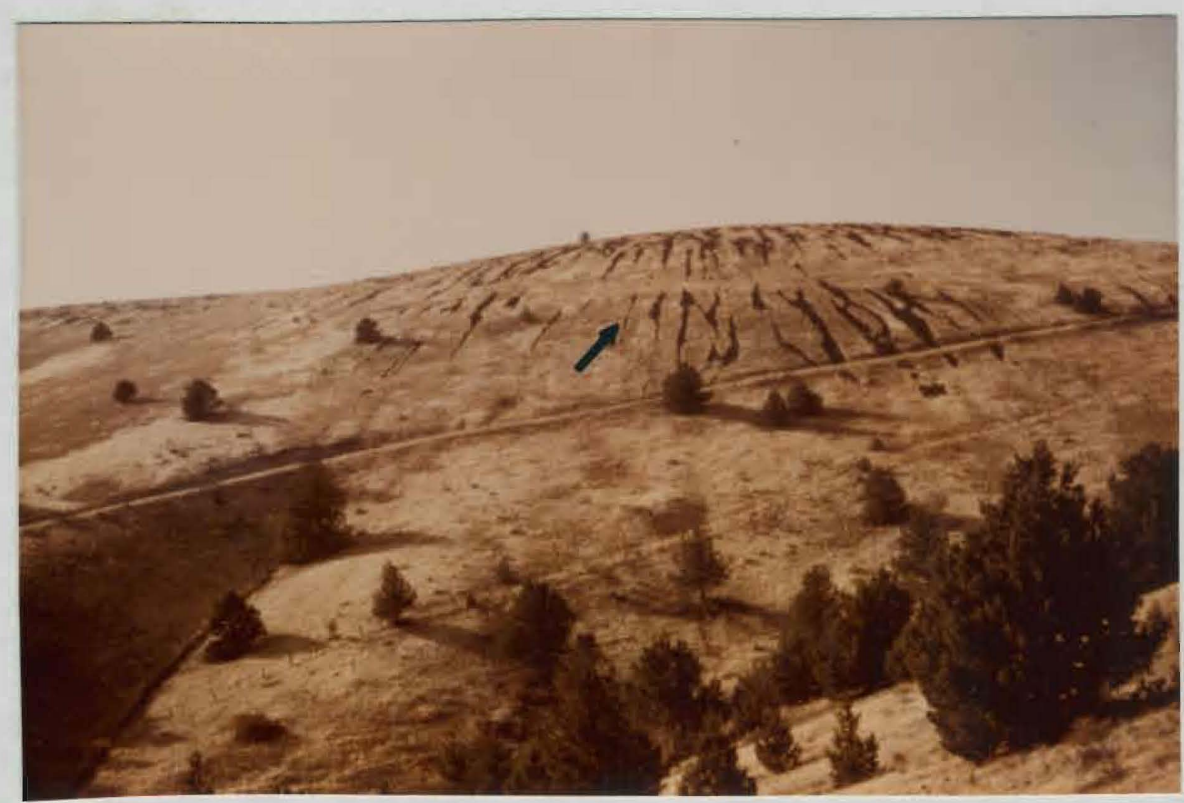

Figure 27. Stone stripe number five, located north of Fossil, is $54 \mathrm{~m}$ long and averages about $1 \mathrm{~m}$ wide. The slope was a gradient of $20.5^{\circ}$ near the stripe's head and $25.5^{\circ}$ adjacent to its toe. The stripe and slope are oriented $90^{\circ} \mathrm{E}$.

Stone stripe number five was $54 \mathrm{~m}$ in length, and averaged about $1 \mathrm{~m}$ in width. There was a bulge in the stripe's head where the width was nearly $2 \mathrm{~m}$. Vegetation encroachment was extensive along the edges of the stripe and was especially evident along the center and toe sections.

The interstripe area varied in width from 4 to $19 \mathrm{~m}$, and averaged about $10 \mathrm{~m}$. It was composed of very stony silt loam surface soils, and stony silty to clayey loam subsoils. These increased in depth from $38 \mathrm{~cm}$ adjacent to the stripe's head and center, to $47 \mathrm{~cm}$ near the toe of the stripe. There was some accumulation of rock material at the ground's surface in the interstripe area, but the evidence of instability was not as great here as it was at the other study sites. Perhaps this is a result of the better vegetative cover at this study site. 

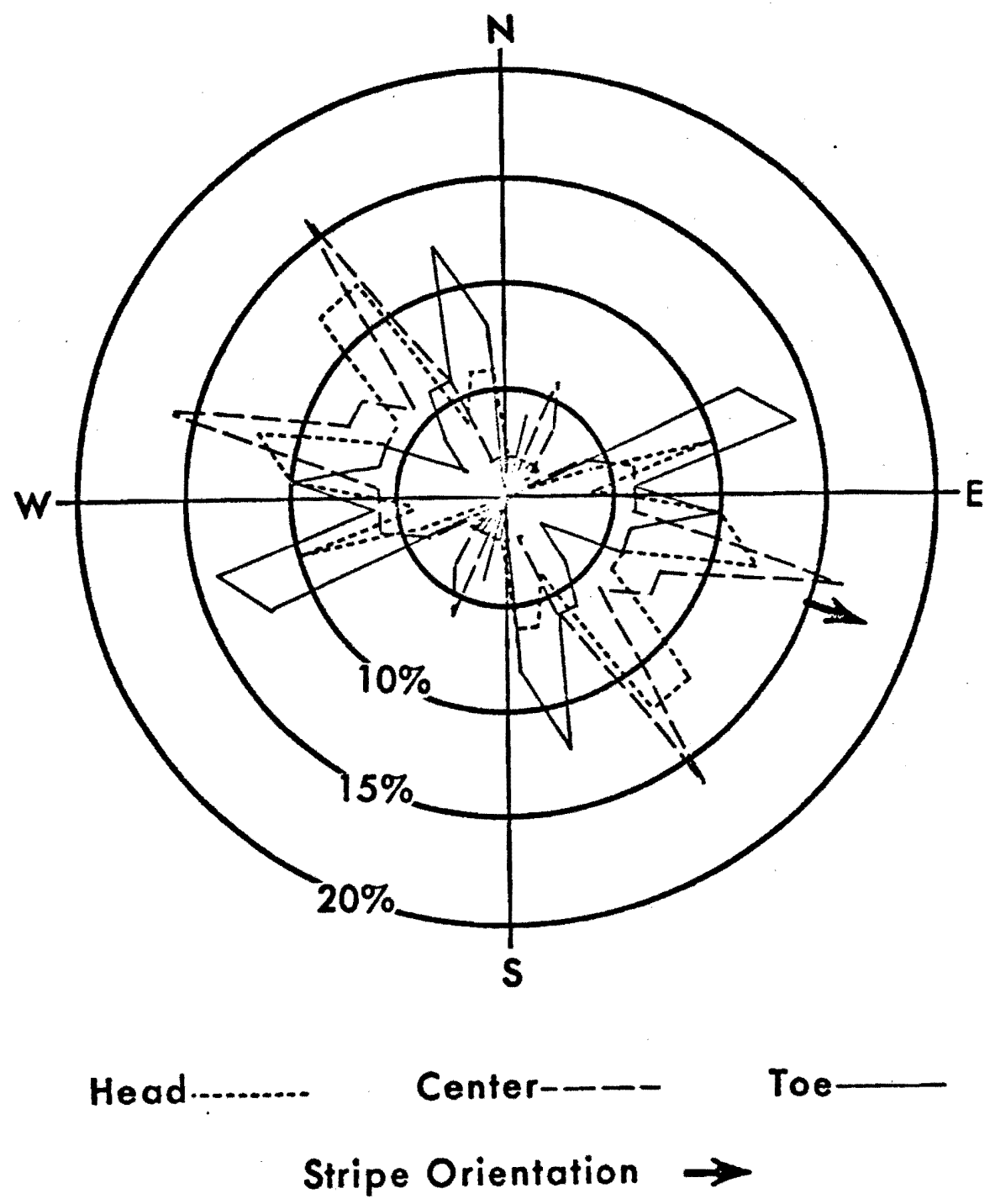

Figure 28. Surface rock orientation diagram for stripe number five. 
Stripe number five was composed of fine-grained, dark-gray to reddish-brown basalt fragments. There was no noticeable spacing or concentration of the larger surface rocks on a lengthwise basis, but rather a scattering throughout the stripe. Surface rock orientation studies did not reveal any strong alignment of the long axes, although there was some tendency for them to line up in the downslope direction (Fig. 28).

The stripe's depth decreased downslope from $55 \mathrm{~cm}$ at the head, to $37 \mathrm{~cm}$ at the center, to $30 \mathrm{~cm}$ at the toe (Fig. 14E). The depth of the soil beneath the stripe varied from $9 \mathrm{~cm}$ at the head, to $4 \mathrm{~cm}$ at the center, to $23 \mathrm{~cm}$ at the toe (Fig. 14E). The soil under the stripe was moist and therefore appeared darker than the drier surface soil (Fig. 30). This indicates that the stripe may help to concentrate moisture along the base of the stripe. The surface of the bedrock below the stripe was jagged and uneven (Fig. 30). At the head cross section, the base of the stripe rested almost on top of the weathered bedrock (Fig. 30). This zone of in situ weathered material seemed to be contributing to the rock mass of the stripe. Perhaps the concentrated moisture facilitates the weathering and upheaving of the bedrock. The bedrock underneath the interstripe areas was jagged and uneven also.

Stripe number five displayed vertical, but no horizontal, sorting within the vertical cross sections, although the sorting did not appear to be as strong as it was in other stripes (Fig. 30). Mean rock sizes for the stripe were $16.2 \mathrm{~cm}$ at the surface, $9.6 \mathrm{~cm}$ in the middle zone, and $6.7 \mathrm{~cm}$ along the base of the stripe. Average surface rock size decreased downslope, so that the largest rocks were concentrated at the 

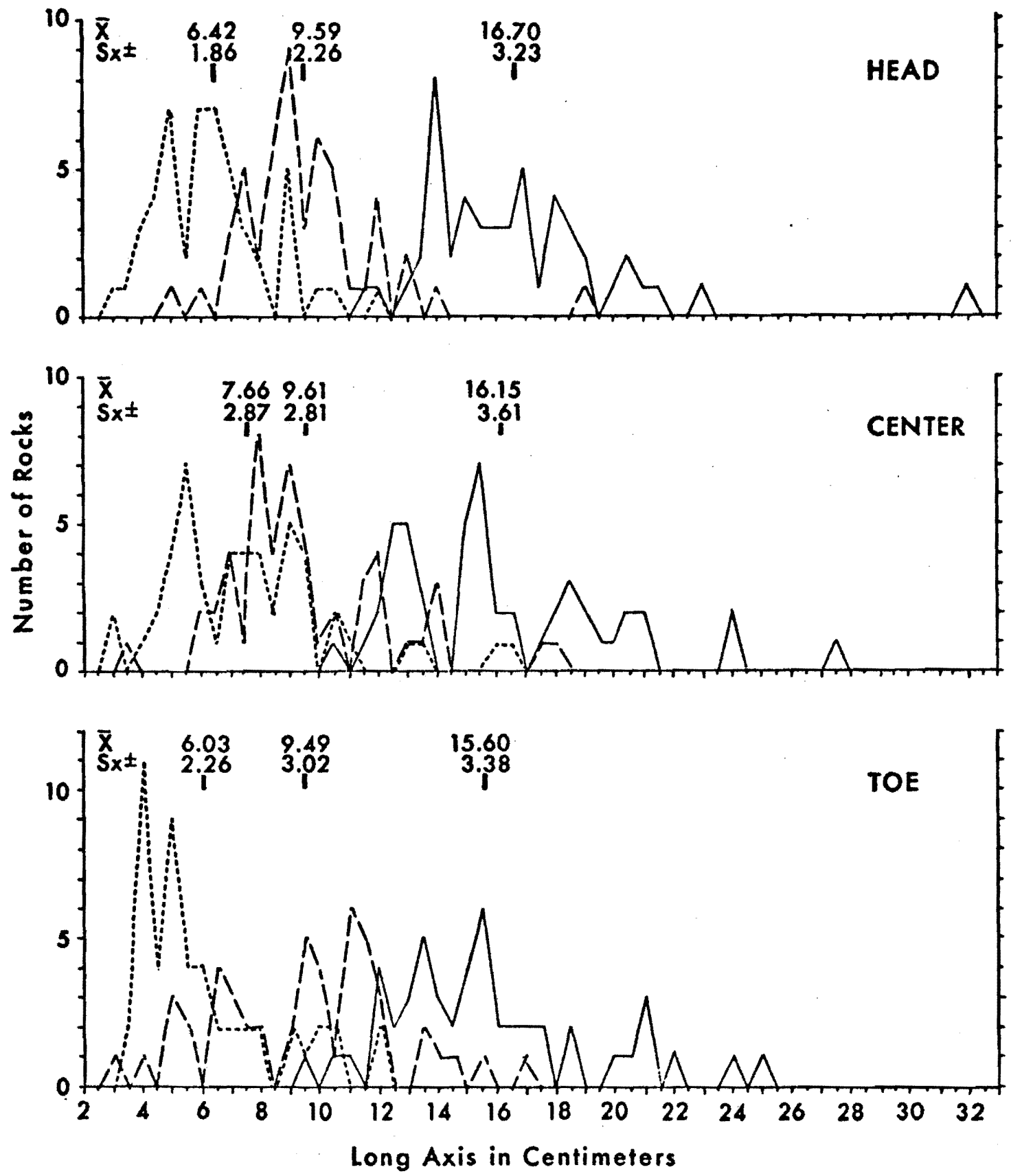

\section{Base.......... Middle - Surface--}

Figure 29. Rock size measurements for head, center, and toe cross sections for stripe number five. 
surface of the stripe's head (Fig. 29). Rocks of the middle zone remained relatively constant in size throughout the stripe. Base rocks did not show any identifiable pattern either, although the smallest rocks consistently occurred at the stripe's toe (Fig. 29). Overall, the standard deviations became less downslope in the middle zone, and varied in no set pattern in the surface and base zones (Fig. 29). They a11 decreased with depth into the stripe.

Several terracettes crossed stripe number five. The treads were level to slightly concave with the adjacent interstripe areas, and the risers were convex with respect to the bordering soil areas (Fig. 14E). Bunchgrass was well developed along the edges of the stripe, with soil and vegetative matter incorporated with the marginal rocks. Vegetation

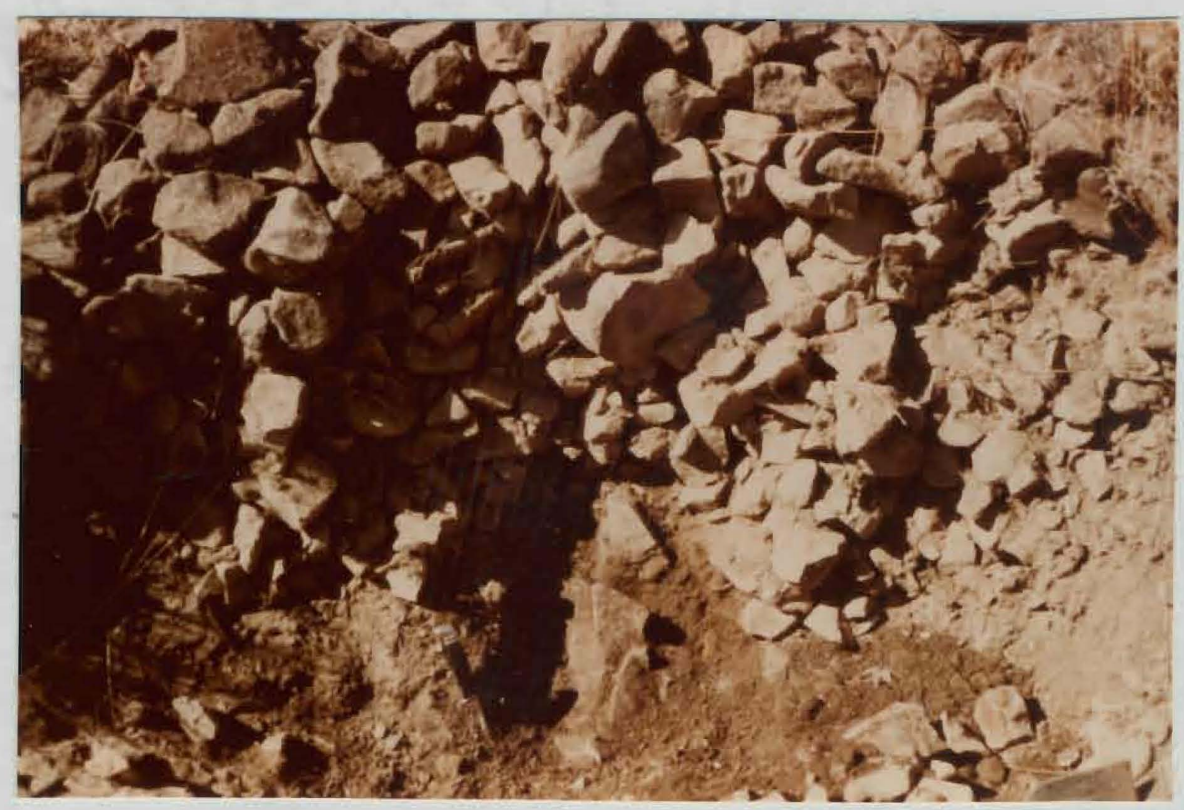

Figure 30. Head cross section of stripe number five. Note the jagged uneven nature of the bedrock surface. The knife is $20 \mathrm{~cm}$ long and provides scale. 
encroachment was especially pronounced at the lower end of the stripe. Stones along the edges and in the middle and base of the stripe were coated with fine soil (Fig. 30).

Mounds were located at the top of the hill, where the stripes seemed to converge and create an intricate array of ground patterns (Fig. 27). No bedrock outcrops were observed. Severa1 stripes in the area exhibited bifurcation and coalescence, while some were sinuous and others were straight.

\section{Study Site Number Five}

The fifth study site was located south of Shaniko, and north of Antelope, close to where State Highway 218 passes over the southerm edge of the Deschutes-Umatilla P1ateau (Fig. 11). Patterned ground and mounds are abundant in this region, with some of the best examples of both types of features on the entire plateau located around Shaniko. Stone stripe number six was situated about halfway down a convex slope that faced $\mathrm{N} 21 \mathrm{OE}$ (Fig. 31). Located below a small lobe of soil, the stripe occupied a $17.5^{\circ}$ slope. Stripe number six was $28.5 \mathrm{~m}$ 1ong and oriented in a $N 19{ }^{\circ} \mathrm{E}$ direction. The stripe ranged in width from 0.5 to $1.7 \mathrm{~m}$, averaging approximate $1 \mathrm{y} 1 \mathrm{~m}$. It extended straight downslope, with its head and toe wider than its center (Fig. 31).

The interstripe area was fairly uniform in width, averaging about $6.5 \mathrm{~m}$, and the soil was an extremely rocky, silty loam that graded into a stony clayey loam subsoil. The depth of the interstripe soil was $32 \mathrm{~cm}$ near the stripe's head, and $20 \mathrm{~cm}$ along the central portion of the stripe (Fig. 14F). The interstripe soil depth increased to $65 \mathrm{~cm}$ 
opposite the stripe's toe. Vegetation was relatively sparse in the interstripe area, with evidence of instability everywhere.

Stripe number six was composed of dark-gray, fine-grained basalt fragments. Several vesicular rocks were interspersed throughout the stripe, and moss and lichen growth was extensive on many of the rocks. Some stones were turned on edge and some were parallel to the slope, but neither characteristic was pronounced. The largest rocks were concentrated at the stripe's lower end, although some larger surface rocks were scattered throughout the stripe. Surface rock orientation studies did not reveal any strong alignment of the long axes (Fig. 32). The stripe's depth increased downslope from $29 \mathrm{~cm}$ at the head, to $31 \mathrm{~cm}$ at the center, to $50 \mathrm{~cm}$ at the toe (Fig. 14F). The depth of the soil beneath the stripe increased downslope from $4 \mathrm{~cm}$ at the head and

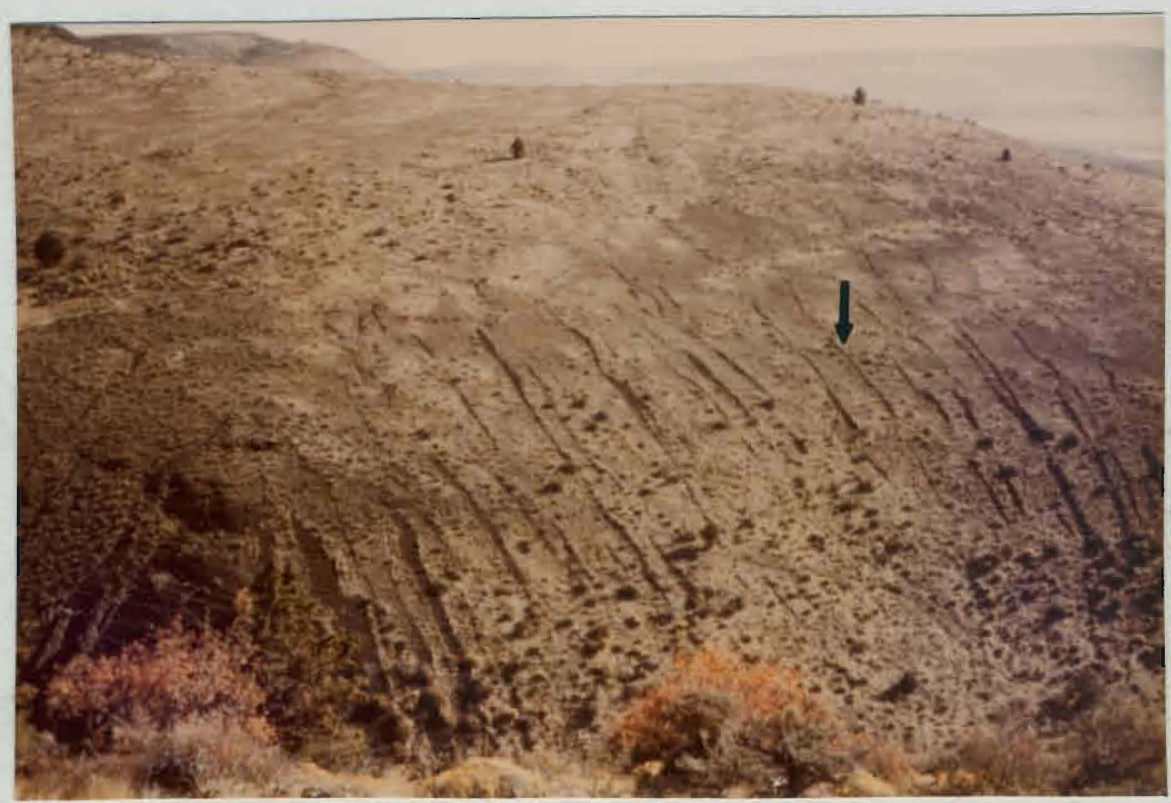

Figure 31. Stone stripe number six, located north of Antelope, is $28.5 \mathrm{~m}$ long and averages about $1 \mathrm{~m}$ wide. The slope has a gradient of $17.5^{\circ}$ and is oriented $\mathrm{N} 21^{\circ} \mathrm{E}$. 

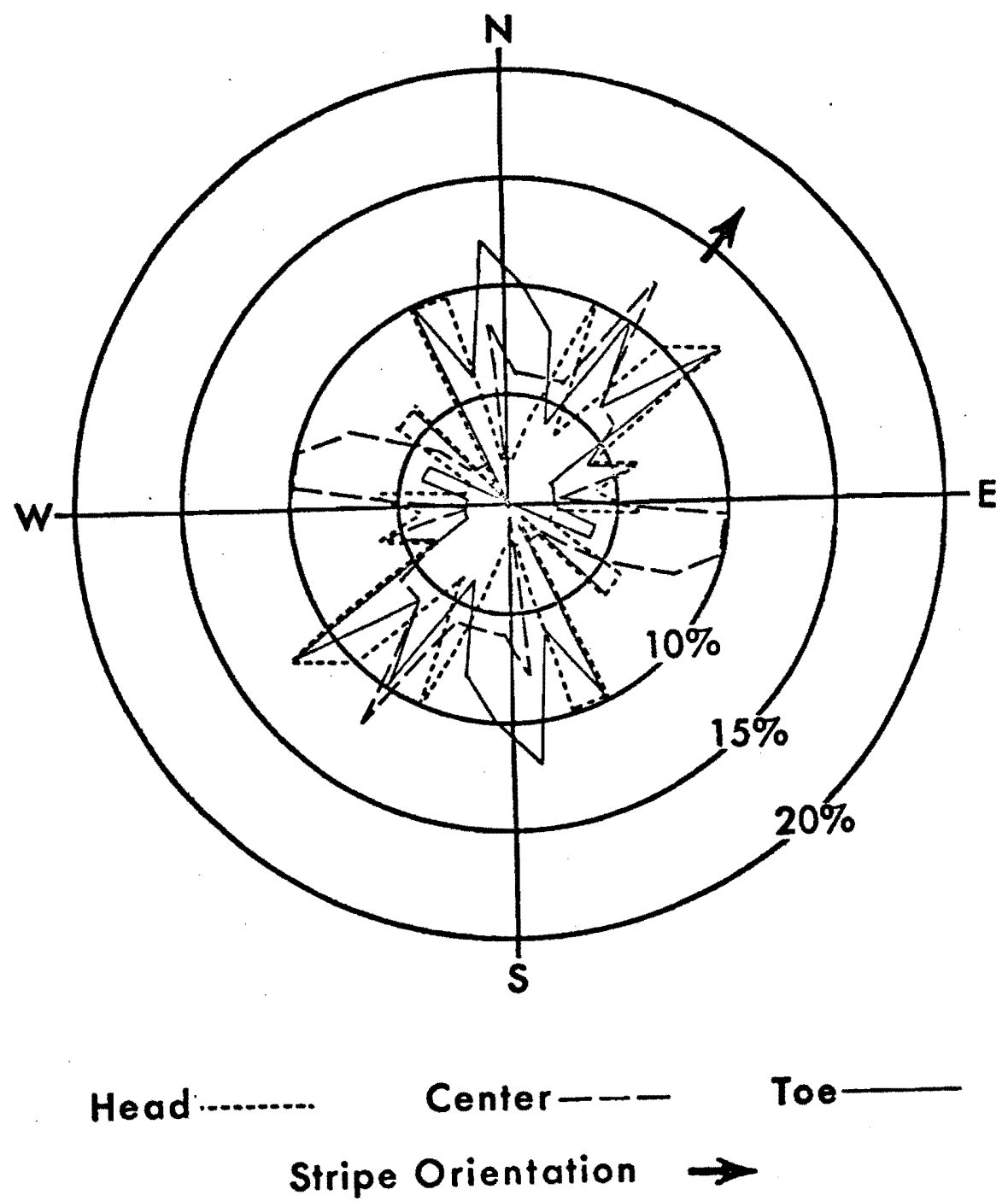

Figure 32. Surface rock orientation diagram for stripe number six. 
center, to $22 \mathrm{~cm}$ at the toe (Fig. 14F). The surface of the bedrock below the stripe was jagged and uneven, with the stripe almost resting on a zone of weathered bedrock at the head and center cross sections. The bedrock underneath the interstripe area exhibited the same characteristics.

In vertical cross section, stripe number six narrowed with depth and exhibited strong vertical sorting. Mean rock sizes from surface, to middle, to base, were $15.8 \mathrm{~cm}, 9.0 \mathrm{~cm}$, and $6.5 \mathrm{~cm}$, respectively. On the average, the largest rocks in each zone were located at the stripe's toe, with the standard deviations not showing any consistent pattern at a11 (Fig. 33).

At each cross section, the stripe rose slightly above the bordering interstripe soil, in convex fashion (Fig. 14F). The rocks along the margins of the stripe were being encroached upon by vegetation, particularly at the lower end of the stripe (Fig. 34). Moss and 1ichen development was quite well established throughout the stripe. At the lower end, some rocks were burying the vegetation.

The entire lower portion of this study slope was covered with stone stripes (Fig. 31). There were no bedrock outcrops close to stripe number six. Mounds occurred upslope, and vegetation was better developed along the lower portion of the slope. The stripes were essentially parallel downslope, of variable widths and lengths, and criss-crossed with terracettes (Fig. 31).

\section{Study Site Number Six}

The sixth and final study site was located north of Willowdale, and south of the Shaniko junction, where U.J. Highway 97 passes through 

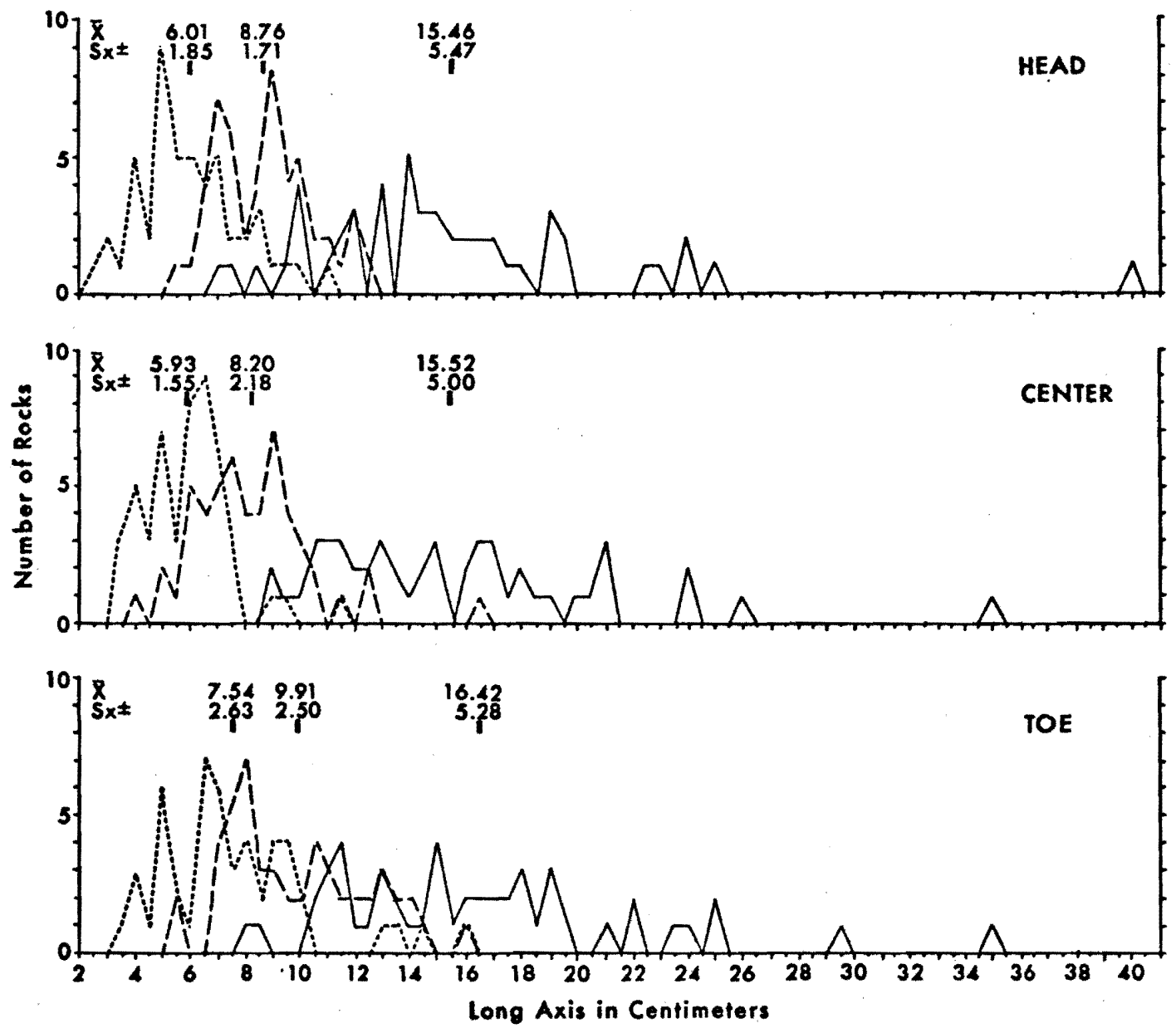

Base -..n....... Middle-_-_- Surface-

Figure 33. Rock size measurements for head, center, and toe cross sections for stripe number six. 


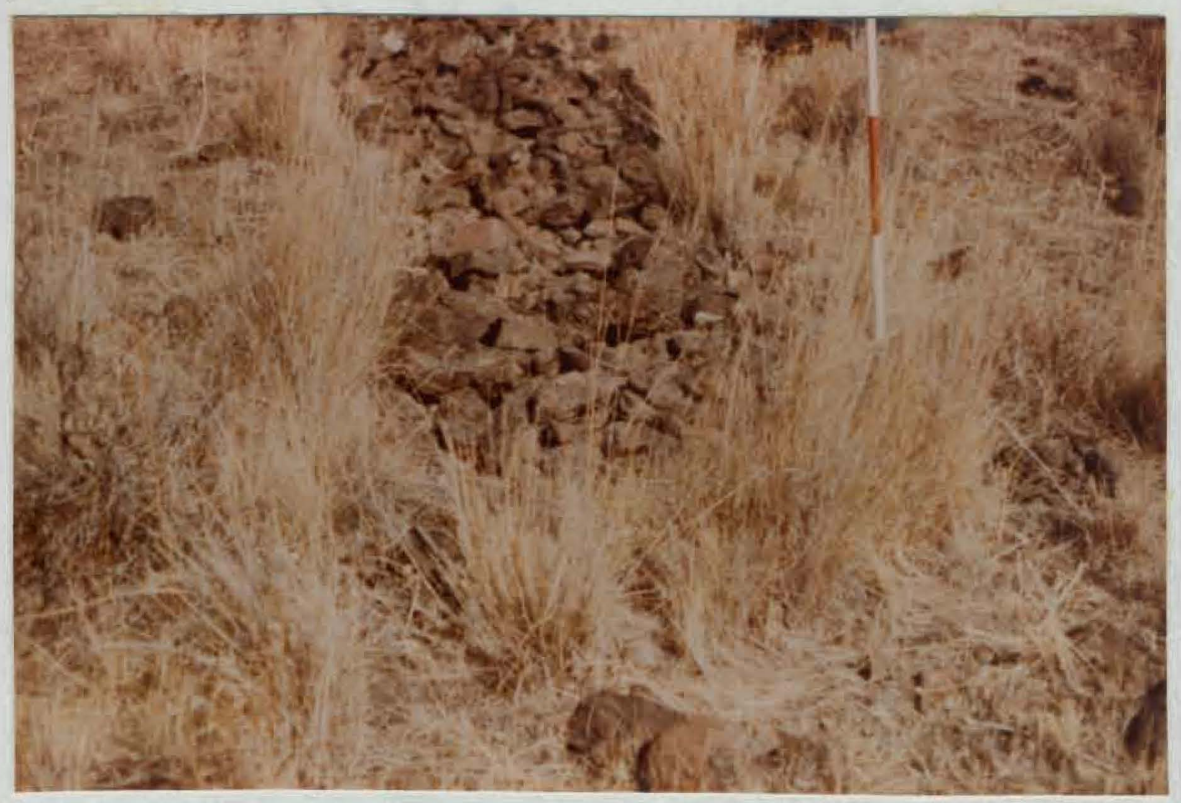

Figure 34. Vegetation encroachment at the lower end of stripe number six. The pole is divided into $30 \mathrm{~cm}$ sections.

Cow Canyon (Fig. 11). Stripe number seven, surrounded by juniper trees, was situated on an open $11.5^{\circ}$ slope that faced $N 63^{\circ} \mathrm{E}$ (Fig. 35). This lower, relatively straight, portion of the slope was separated from the rounded, convex, upper slope by an outcropping of bedrock (Fig. 35). Stripe number seven started just below this outcrop and at first extended downslope $42.4 \mathrm{~m}$ in a $\mathrm{N} 75^{\circ} \mathrm{E}$ direction, then shifted to a $\mathrm{N} 61 \mathrm{OE}$ orientation, which it maintained for most of its length. The stripe had a large, almost circular, head that was $3.5 \mathrm{~m}$ across. It narrowed in width downslope, so that the center and toe sections averaged about $0.5 \mathrm{~m}$ across (Fig. 35).

The interstripe area ranged from 2 to $7 \mathrm{~m}$ in width, but averaged about $5 \mathrm{~m}$. The interstripe soils were composed of very stony silt to silt loam, and decreased in depth downslope from $51 \mathrm{~cm}$ near the stripe's 
in

ㄴ?

$\circ 0$

थ

$00 .-1$

㻤

$\sum_{0}^{2} 4$

๘

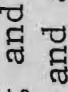

되

글

घ

$+4$

ํ.

ษ

叶

द्व

द्व है

त्

$\checkmark$

हु สี

บ

步

도

पृ

익

$n^{\mathrm{E}}$

हुं.

垫

क

4 거

d)

自 क

व

(1) 우

a

望 듕

c) मे

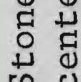

us

ली 
head, to $27 \mathrm{~cm}$ opposite the center, to $25 \mathrm{~cm}$ adjacent to the toe of the stripe (Fig. 14G). Evidence of instability was abundant in the interstripe area, and vegetation was poorly developed because of the extremely rocky soil.

Stripe number seven was composed of fine-grained, dark-gray to reddish-brown basalt fragments. Surface rock orientation studies did not reveal any alignment of the long axes with respect to stripe or slope orientation (Fig. 36). The larger rocks seemed to be distributed primarily throughout the lower half of the stripe.

The stripe's depth decreased downslope from $39 \mathrm{~cm}$ at the head, to $29 \mathrm{~cm}$ at the center, to $20 \mathrm{~cm}$ at the toe (Fig. 14G). The depth of the soil beneath the stripe remained fairly constant for the length of the entire stripe, ranging from 3 to $8 \mathrm{~cm}$ (Fig. 14G). Resting on top of the consolidated basement material there was a zone of in situ weathered bedrock consisting of angular particles that were easily removed from their resting places. It appeared that this zone was contributing to the rock mass of the stripe. The area beneath the interstripe soil exhibited similar conditions.

In vertical cross section, the stripe narrowed with depth and displayed vertical sorting. Mean rock size for the surface was $12.7 \mathrm{~cm}$, for the middle it was $8.4 \mathrm{~cm}$, and for the base it was $5.8 \mathrm{~cm}$. The average rock sizes did not show any consistent pattern from head, to center, to toe (Fig. 37). The standard deviations of these rock size measurements averaged less with depth into the stripe (Fig. 37).

The stripe and interstripe surfaces were relatively level in the head cross section, but in the lower sections of the stripe, terracettes 

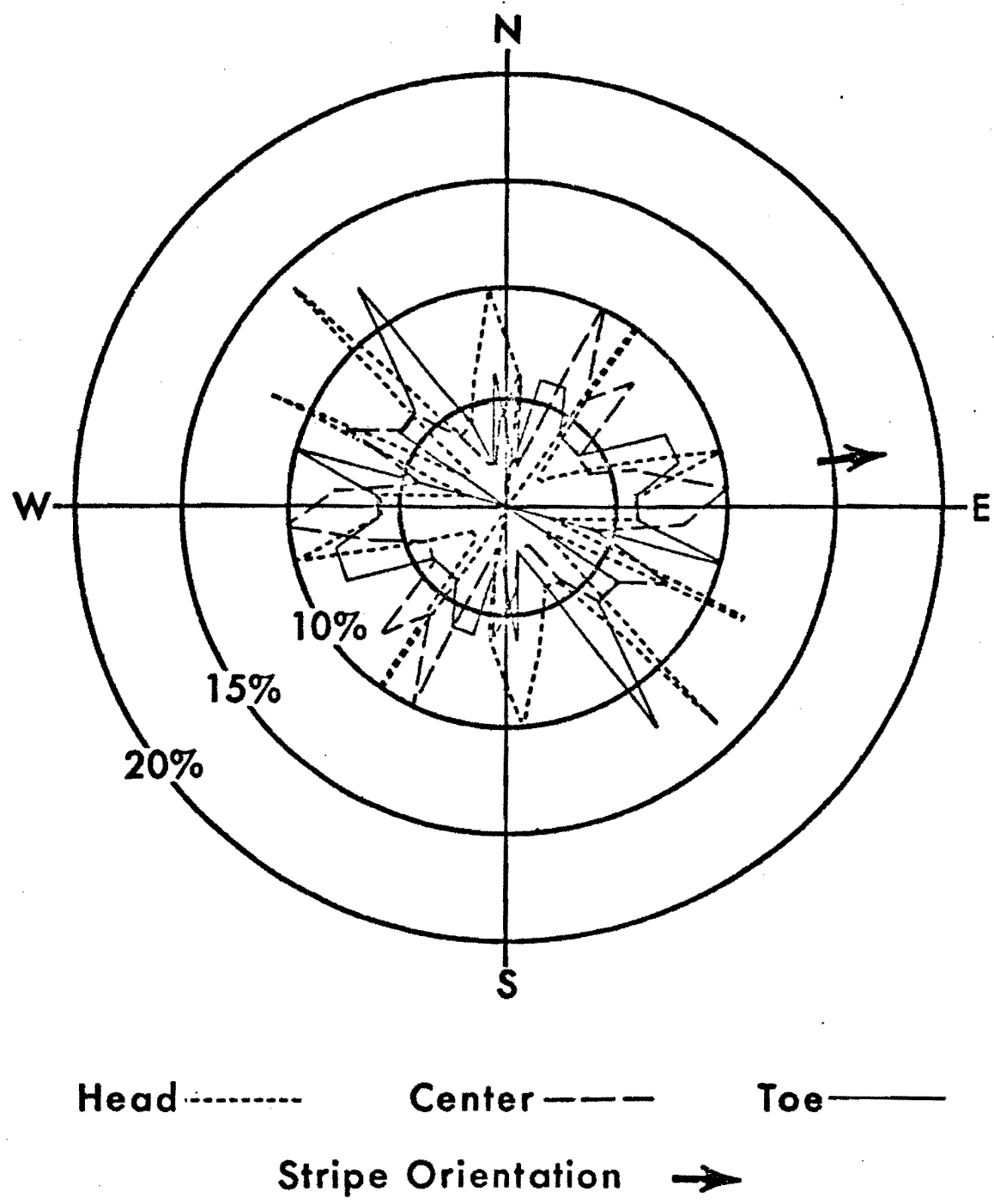

Figure 36. Surface rock orientation diagram for stripe number seven. 

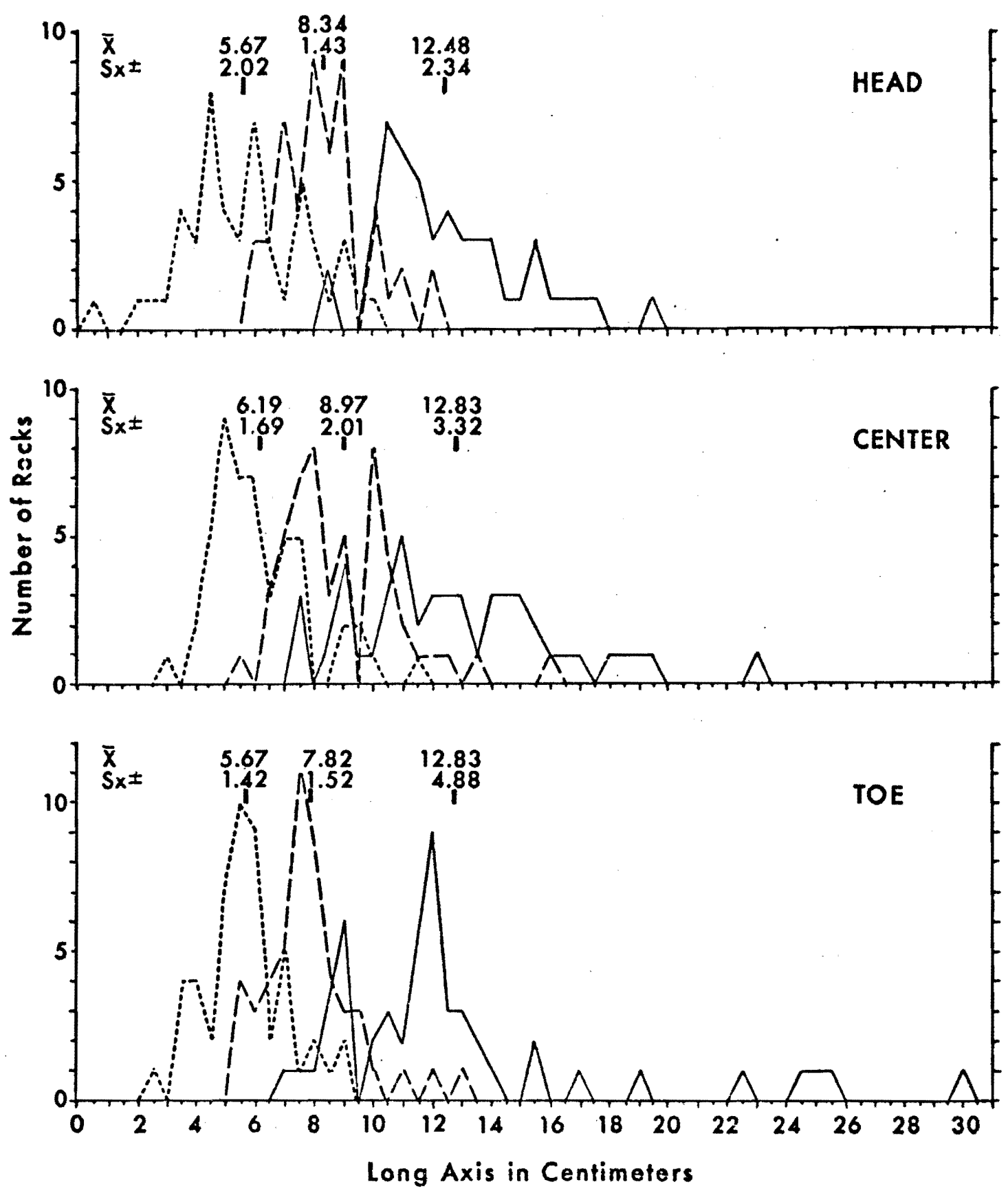

Base-....... Middle-- - Surface-

Figure 37. Rock size measurements for head, center, and toe cross sections for stripe number seven. 
engendered considerable modification. The treads were level to slightly concave, and the risers were convex in relation to the interstripe soil surfaces (Fig. 14G). The rocks at the base and along the margins of the stripe were covered with fine soil. There was ample evidence of adjacent interstripe material being forced onto and into the edges of the stripe (Fig. 38). Because vegetation was sparse, encroachment was not very evident. A good-sized juniper tree was growing at the downslope termination of the stripe.

Stripe number seven was surrounded by other well developed stripes, all paralleling each other downslope. Several young juniper trees were invading the slope (Fig. 35). Some mounds and other forms of patterned ground were found upslope from stripe number seven.

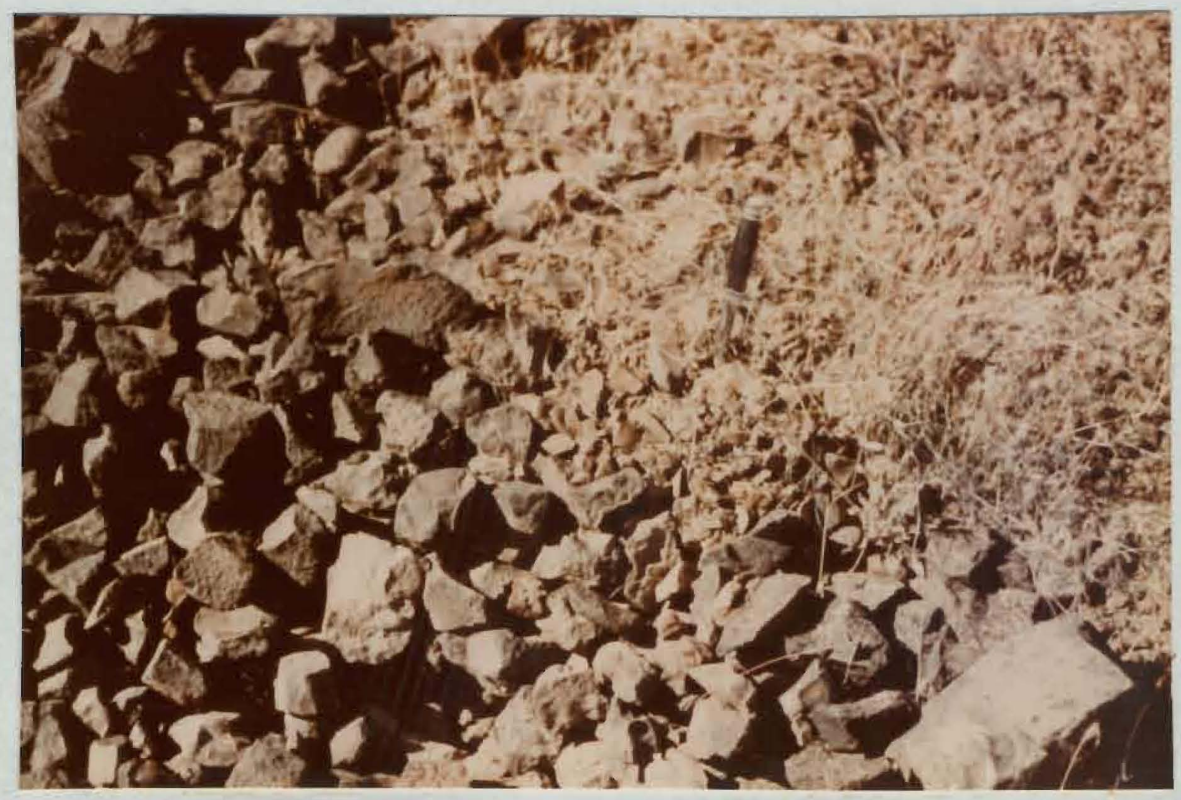

Figure 38. Interstripe material is being forced on and into the edge of stripe number seven. Knife is $20 \mathrm{~cm}$ long and provides scale. 


\section{SUMMARY AND INTEGRATION}

North central Oregon stone stripes are composed of fine-grained, dark-gray to reddish-brown basalt fragments, as the entire study region is underlain by the vast Columbia River Basalt lava series (Fig. 3). The stripes do not occur once the basalt plateau is left, except in a few isolated mountain areas at substantially higher elevations (Weide 1972). Also, stone stripes are found only in the central and southern sections of the Deschutes-Umatilla Plateau, where the soil depth averages less than $1 \mathrm{~m}$ (Fig. 39). Field reconnaissance, coupled with an examination of aerial photographs, generally did not reveal that stone stripes developed on one particular exposure more than any other. However, this is not to say that in local situations exposure may not have been an important factor, especially as it relates to available moisture and vegetation development. Altitude appears to have played an important role in stripe formation, for the best developed features occur in areas of higher elevation, such as along Tygh Ridge, near Shaniko, north of Fossil, around Lonerock, and south of Hardman, or wherever the elevations range from 900 to over $1100 \mathrm{~m}$ (Fig. 2).

Generally, stone stripes in the thesis area occur on convex or straight slopes. On rounded, convex slopes, stripes radiate from the summit, with the distance between individual stripes increasing downslope (Fig. 27). On uniform, or straight, slopes, the stripes form long parallel lines of dark basalt blocks, separated by wider strips of grass-covered soil (Fig. 24). The stone stripes can be found where the slope angle is greater than $2^{\circ}$; however, they seem to be most prevalent 


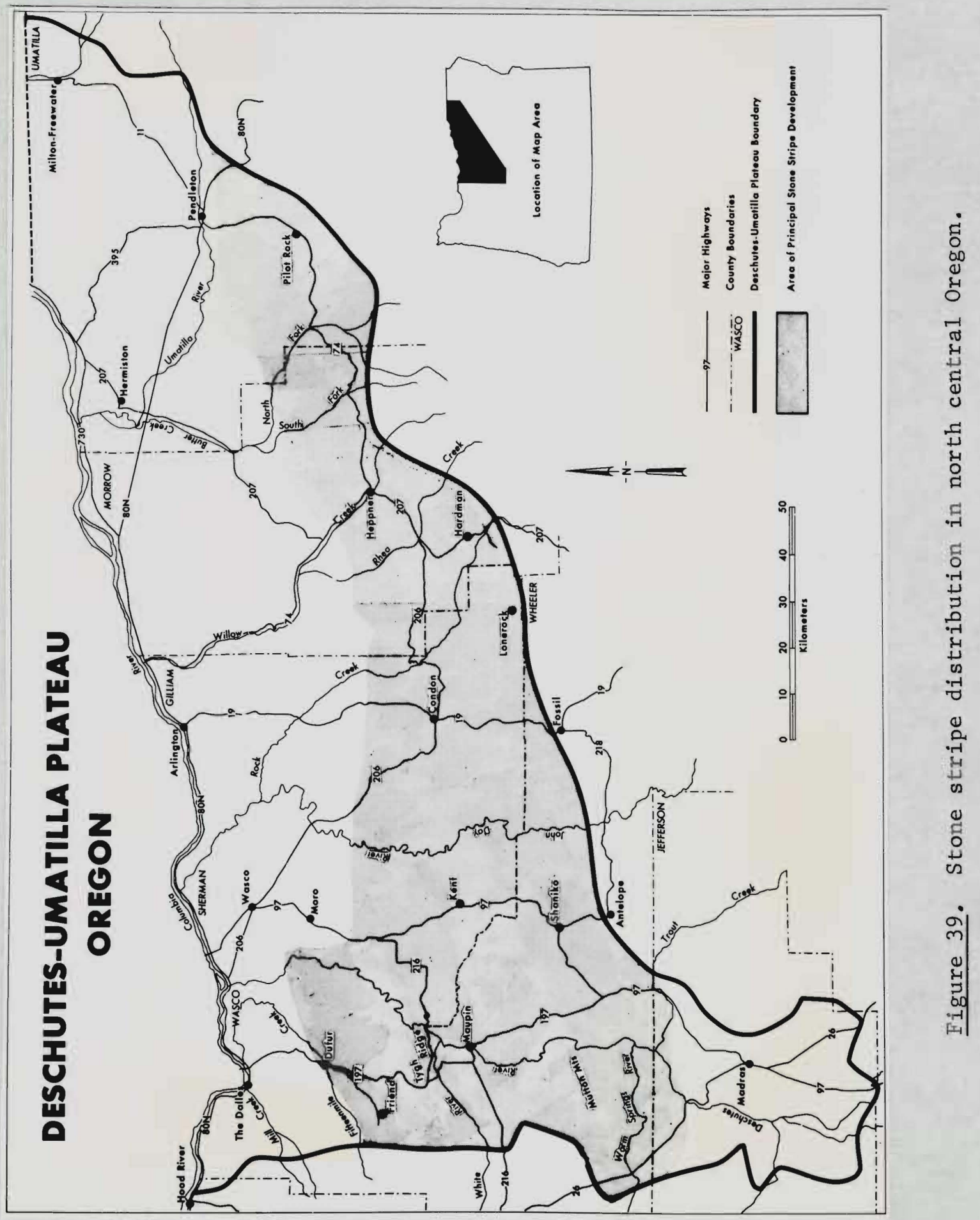


on slopes between $15^{\circ}$ and $30^{\circ}$. The maximum gradient on which I have observed them is $31^{\circ}$. On less steep slopes, the tabular rock fragments may be on edge, fitted firmly together, and oriented parallel to the direction of the stripes. More commonly, however, the stones are rather loosely arranged, with 1 ichen growth and vegetation encroachment extensive. Surface rock orientation studies suggest that the long axes of stones in the stripe are not as strongly aligned in the slope and stripe direction as was expected. This may be, however, simply a function of the investigated stripes' age, reflecting disturbance since they were formed.

North central Oregon stone stripes do not appear to have any typical length or width (Table II). They range from a few meters to wel1 over 150 in length, and their widths vary from 0.3 to $3 \mathrm{~m}$ or more. In fact, the width of each individual stripe often fluctuates throughout its length (Table II). I am sure that vegetation encroachment contributes to this variation in the stripes' width. The stripes may be sinuous with coalescence and bifurcation common. Frequently they become straighter and more clearly defined as they descend the slope, although the reverse is also true. The interstripe areas are usually much wider than the stripe and can be greater than five or six times the width of the stripe. These accompanying bands of finer material are composed of very stony silt to silt loam surface soils that frequently grade into stony silty clayey loam subsoils. The depth of the interstripe soil is extremely variable and ranges from 0.2 to over $1 \mathrm{~m}$ (Table II). Evidence of instability is pronounced in all of the interstripe areas. Upheaved stones and vegetation, along with frost boils and small patches of solifluction, are found everywhere. 
Measured stripe depths ranged from 20 to over $65 \mathrm{~cm}$ and does not appear to be related to stripe width or to position on the slope as reported by Sharp (1942, p. 296) (Table II). However, as one would expect, stripe depth is related to the distance bedrock is located below the ground's surface (Table II). Stone stripes were found resting on weathered bedrock in areas where the soil mantle is sha1low, but most often they are underlain by several centimeters of soil, similar to that found in the interstripe areas (Table II).

In vertical cross section, the stripes normally decreased in width downward and the rocks comprising the stone stripes also became smaller with depth. The stones vary in size from a few centimeters to over half a meter, but average about $10 \mathrm{~cm}$ in diameter. Because of the vertical sorting, however, an average rock size for the entire stripe does not have much meaning. Studies on the relationships between particle size and depth revealed that overall vertical sorting occurs in a rock size ratio of about 2.5 to 1.5 to 1 , from surface, to middle, to base (Table III). That is, surface rocks average about 2.5 times larger than rocks from the base of the stripe, and stones from the middle zone are normally about 1.5 times larger than the base rocks (Table III). Also, the standard deviations of these rock size measurements decreased with depth into the stripe, so that the rocks not only became smaller but more uniform in composition, as they progress downward (Table III).

Source material for the development of north central Oregon stone stripes appears to have originated from two places: (1) basalt outcrops; and (2) the underlying weathered bedrock. Frequently, basalt outcrops are located at the heads of stone stripes, providing source material for 


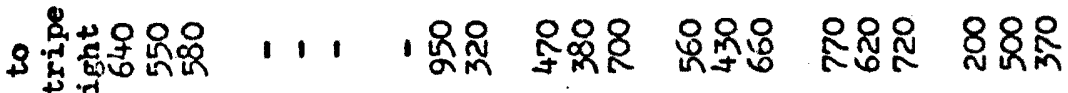
of

运

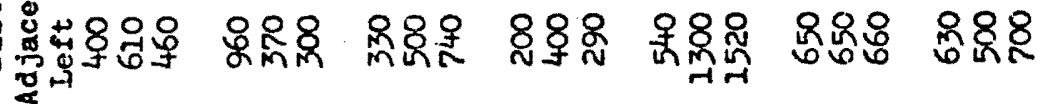

旁

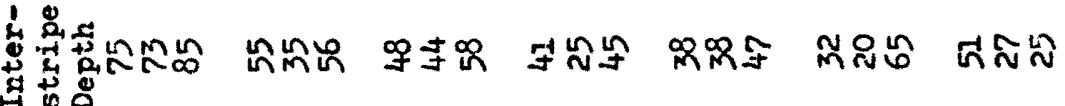

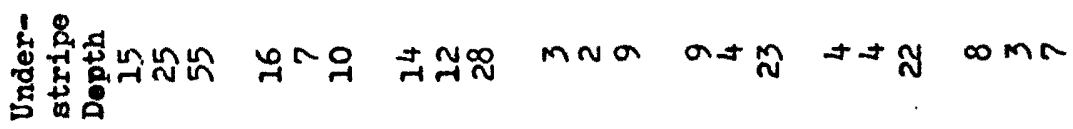

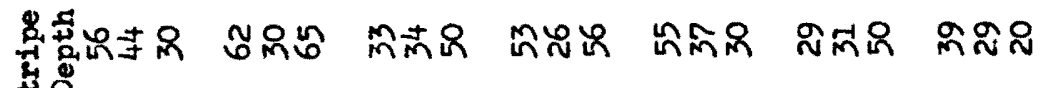

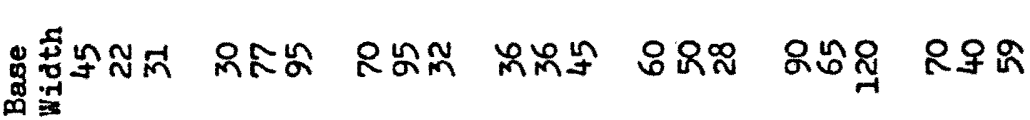

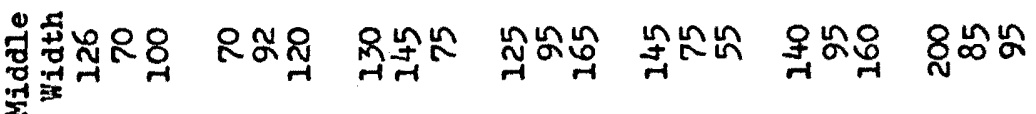

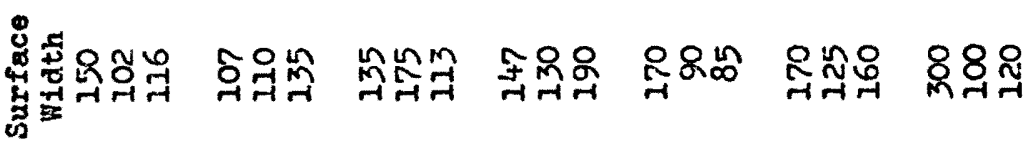

留

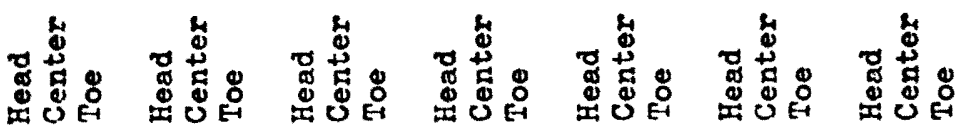

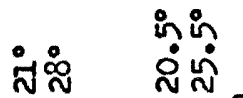

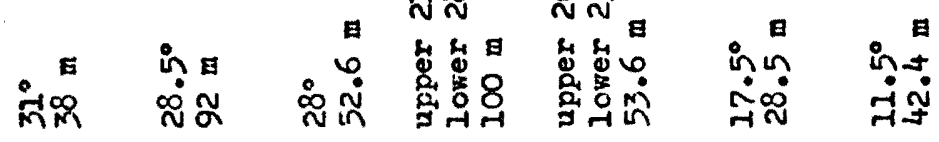

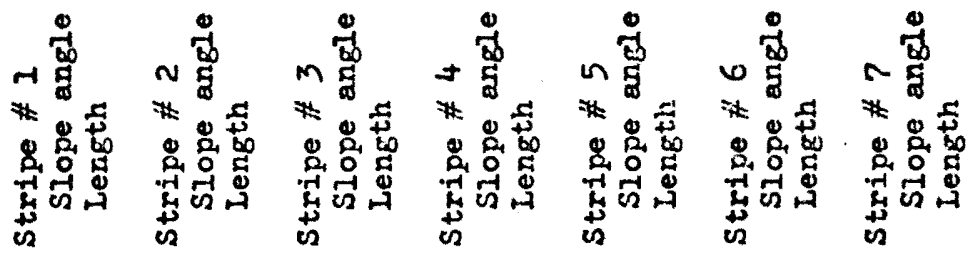


TABLE III

SUMMARY OF ROCK SIZE MEASUREMENTS"

(in $\mathrm{cm}$ )

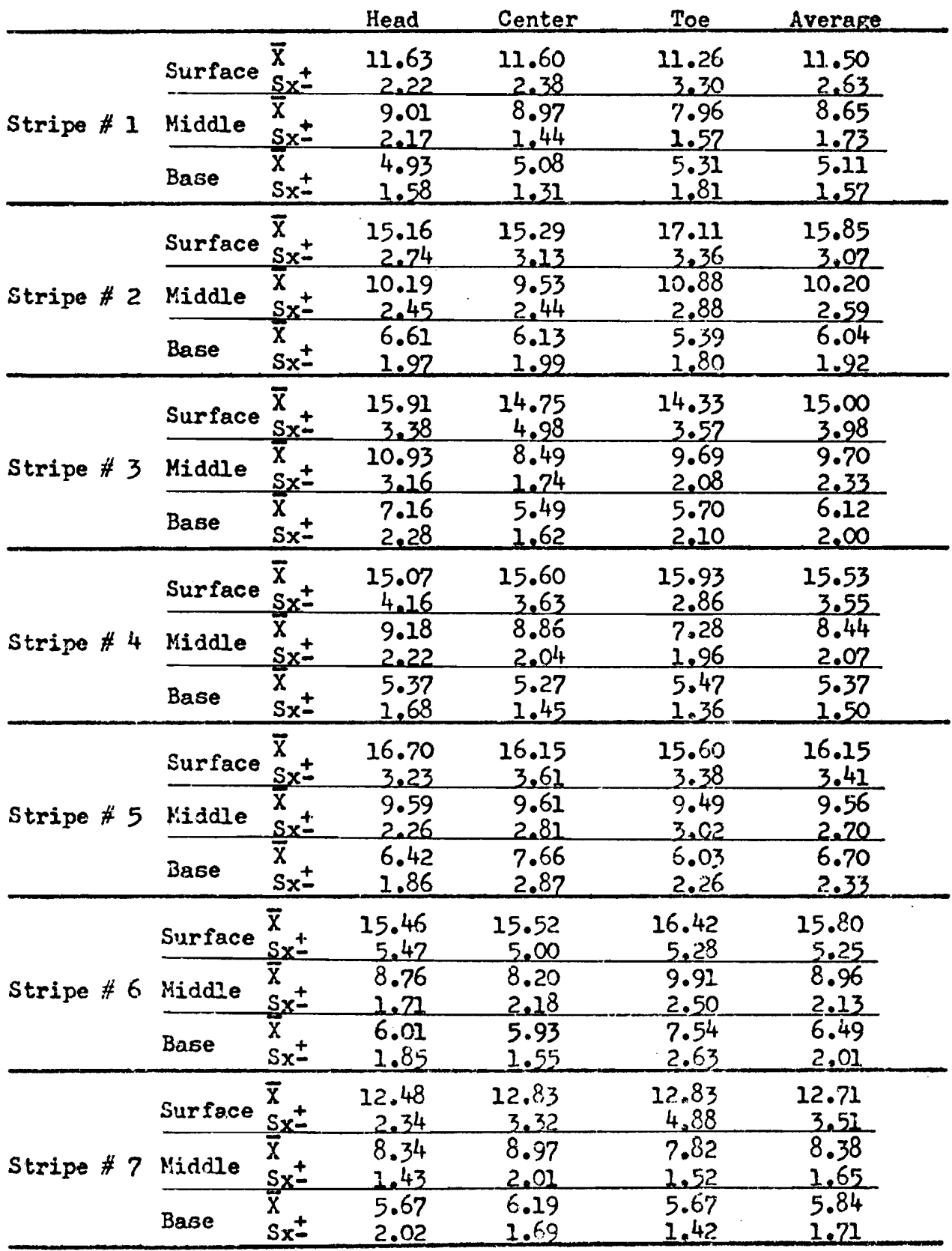

- The differences between the aurface, the middle, and the base means of each etripe was found to be significant at the $99 \%$ level of statistical significance according to the "t" test. 
the stripe's development. It also is common for the stripes to pass over outcrops as they extend downslope, picking up additional rock debris. Furthemore, there are several instances where stripes rest on the underlying weathered bedrock. Source material is undoubtedly supplied in this manner, as well as by upward migration of stones from the buried bedrock.

Rock angularity varies from region to region and throughout the length of each stripe because of the difference in the basalt fracturing. Surface rocks are frequently more weathered than buried rocks, although the reverse also may be true. The vesicular rocks are often more rounded, as are the rocks forming many of the stripes around Shaniko. In the latter case, this may be a function of age, because this is one of the highest areas on the entire plateau (Fig. 2).

Most of the stripes have an appearance of long stability. Lichen and moss growth is well developed on most of the stripes. Vegetation encroachment is covering the stripes, from the edges toward the center. Soil is infilling the voids between the rocks of the stripes. This soil is supplied by the adjacent interstripe areas and seems to be almost forced into the stripes. Fine soil caked the rocks that make up the middle and base of the stripe.

Some stripes exhibit a spacing of larger rocks, but this is not universal. Terracettes are a major feature altering the stripe's form. The relationship of stripes to other forms of patterned ground is not always clear. The stone stripes most frequently occur by themselves on the steeper slopes. Only on the less steep slopes is there any connection that can be traced directly to other ground patterns. 
Although only seven north central Oregon stone stripes were studied in detail, there was a strong similarity in appearance between the stripes throughout the pleateau. The characteristics I have outlined in this summary would probably hold for most of the stripes in the study area, even though there may be differences in the sizes of the rocks making up stripes from location to location because of the variations in basalt fracturing. 
CHAPTER VI

\section{CONTEMPORARY GEOMORPHIC ACTIVITY}

\section{MODIFICATION BY MAN'S INELUENCE}

Within the last century, many north central Oregon stone stripes have undergone considerable modification. This has come about through grazing pressure since the introduction of cattle and sheep. In order to negotiate the steep hillsides of this region, the animals have developed, or at least used, an intricate system of trails or terracettes (Rahm 1962) (Fig. 20). These occur as miniature step-like features across the slopes, and where the terracettes traverse stone stripes, they are also separated into a series of treads and risers (Figs. $20 \& 40$ ). However, where it crosses the stripe, the terracette is very subdued as compared to the interstripe features because the risers correspond more closely to slope angle than to the nearly vertical form that is normally associated with risers on the side of a hil1 (Fig. 40).

The treads on stripes are usually characterized by more compacted stones, an absence of larger rocks, a flattening of the stripe, and increased soil and vegetation encroachment (Figs. $21 \& 40$ ). These factors produce a narrowing in the stripe's width at this point. In contrast, when the risers cross a stripe, the stripe widens, the stones are loosely arranged, and there is a general absence of vegetation and interstitial soil (Figs. $21 \& 40$ ). In vertical cross section, the surface of the stripe is level to slightly concave where the tread 


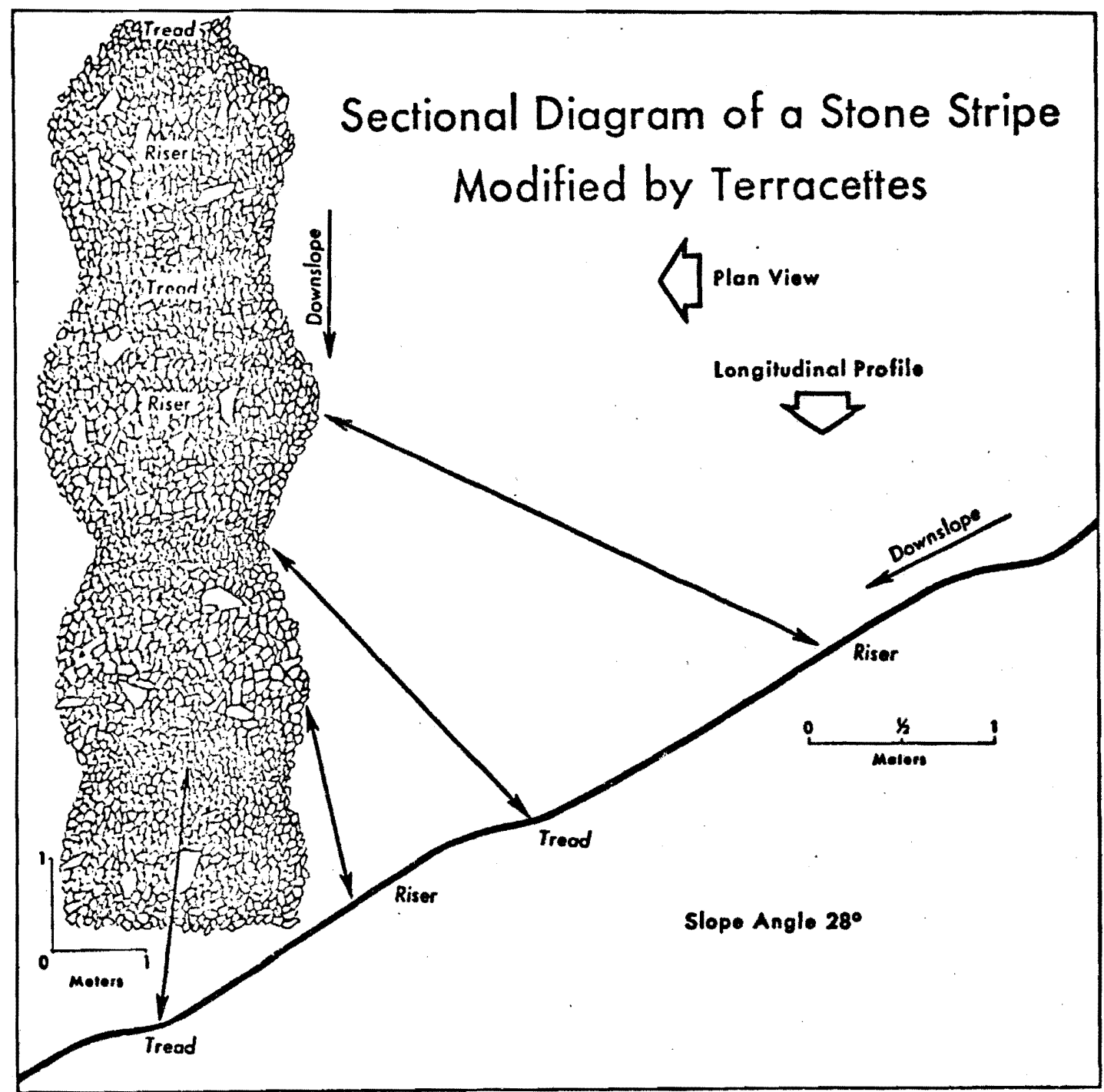

Figure 40. Schematic diagram showing how terracettes modify a stone stripe. Notice the subdued nature of the treads and risers. These features are not as sharply defined as the terracettes located in the adjacent interstripe areas. 
crosses the stripe, whereas the riser is slightly convex, protruding above the adjacent interstripe soil surfaces (Figs. 14C, E, G \& 40). The development and use of terracettes has probably substantially increased the overall downslope movement of the stripes in the study area, since walking on the terracettes exerts pressure downslope and any rocks distrubed would have a net downslope migration. The long range effect of this process is hard to assess, although it is certain that considerable disruption in the continuity of the stripes has taken place in the last century (Figs. 20, 21, $31 \& 35)$. Since vegetation encroachment is facilitated along the treads, one long term effect would be greater stability, with an eventual separation of the stripes into a series of unconnected stony islands extending downslope. Over the years, the number of cattle grazing in the study area has been sharply reduced because of the depletion of natural grasses. The less intensive use of the terracettes appears to be just enough to maintain the terracettes with some disturbance where stripe crossings take place other than on treads.

The heavy grazing of cattle and sheep has severely reduced the presence of native bunchgrasses. Although these have largely been replaced by sagebrush and Cheatgrass, they are not as effective in protecting the soil from erosion (Daubenmire $1959, \mathrm{p} .290$ ). As a result, serious erosion of the soil has resulted from over-grazing since the area was settled.

\section{RATES OF SURFICIAL ROCK CREEP}

Ample evidence of slope instability is found throughout the Deschutes-Umatilla Plateau. The presence of overturned and upheaved 
soil, rocks, and vegetation, as well as mud flows and slumping reflects the relative instability of slopes. In order to document more precisely the importance of these processes, several painted rock measurement sites were established in the Butler Canyon study site (study site number one, Fig. 11). Six main sites, involving over 75 measurement rocks, were established in July 1970. Three of the measurement sites were established on slopes with well developed stone stripes and these provided information on the movement of stripe and interstrife areas (Fig. 41). The remaining three sites provided information on the movement of surface rocks on a steep NW facing slope where there is evidence of recent slumping and mud flow (Fig. 41).

\section{Painted Rock Measurement Site A}

This site is located on a $26^{\circ}$, convex slope that faces $554^{\circ} \mathrm{W}$ (Fig. 41). Vegetation was poorly developed and evidence of instability was pronounced. The stone stripe is $51 \mathrm{~m}$ long and oriented $548^{\circ} \mathrm{W}$. Distances to 33 in situ rocks were measured from bedrock reference points above and below the stripe (Fig. 42). Mean downslope movement for all the rocks was $9.9 \mathrm{~mm}$ a year, with movement over the two-year period ranging from 4 to $52 \mathrm{~mm}$ for individual rocks (Fig. 42). On the average, interstripe rocks moved downslope $3.3 . \mathrm{mm} / \mathrm{yr}$ faster than stripe rocks, with the former averaging $12.3 \mathrm{~mm} / \mathrm{yr}$ and the latter $9.0 \mathrm{~mm} / \mathrm{yr}$. However, because of the small number of interstripe rocks, the difference in movement between stripe and interstripe rocks was not statistically significant according to the " $t$ " test. 


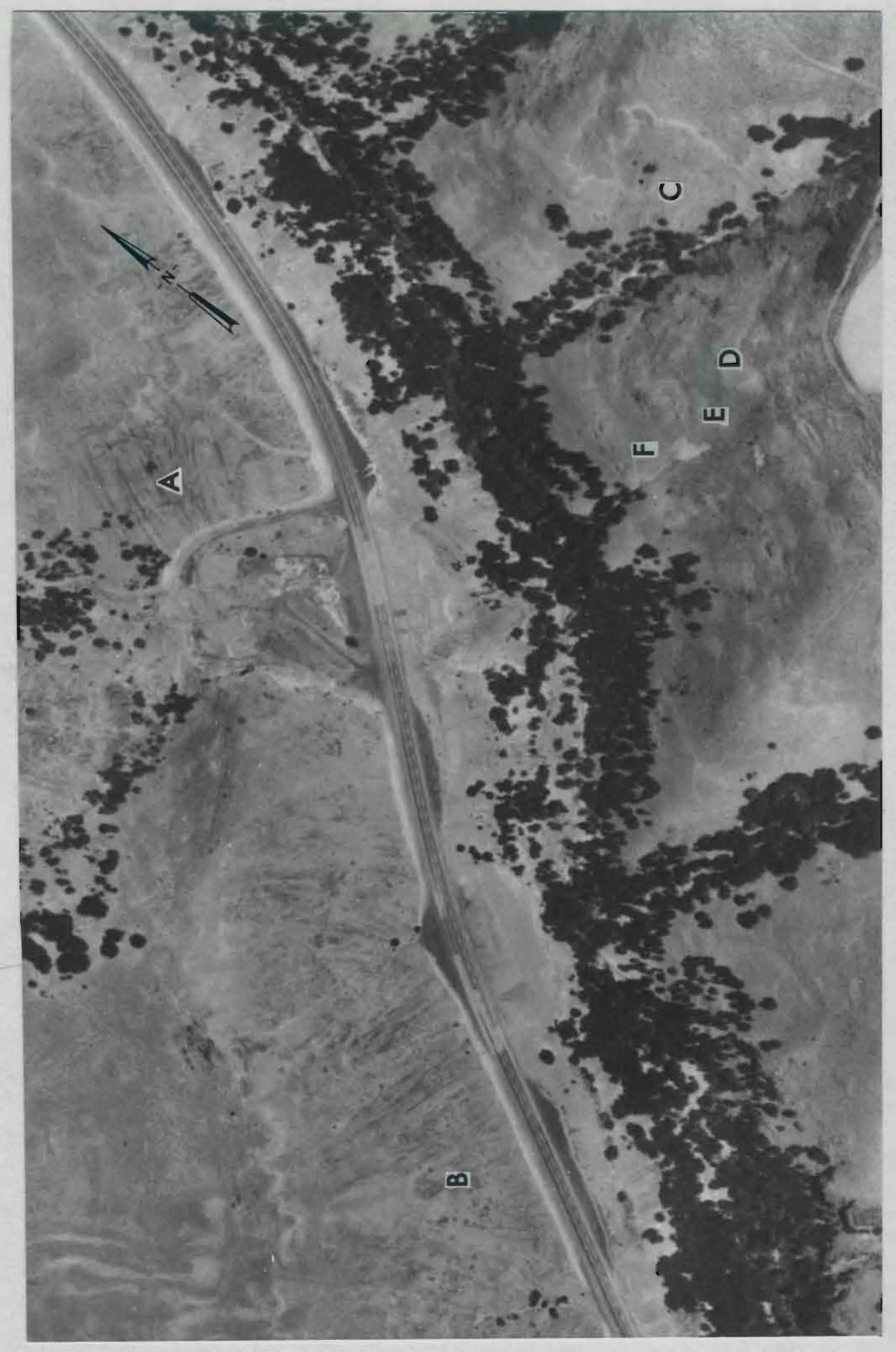

की

(1)

\&ै का

ß

क 굼

is is

os

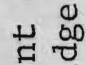

멈

엉

过

ชै से

()

है

บै

\&

त

के म्न

담

ค.

\&) 5

मु

है

य

¿.

암

प 02

ปิ

足

莡

का

:

म्न 4

-

迆实台

ค

थ u क

的茳

ث| 


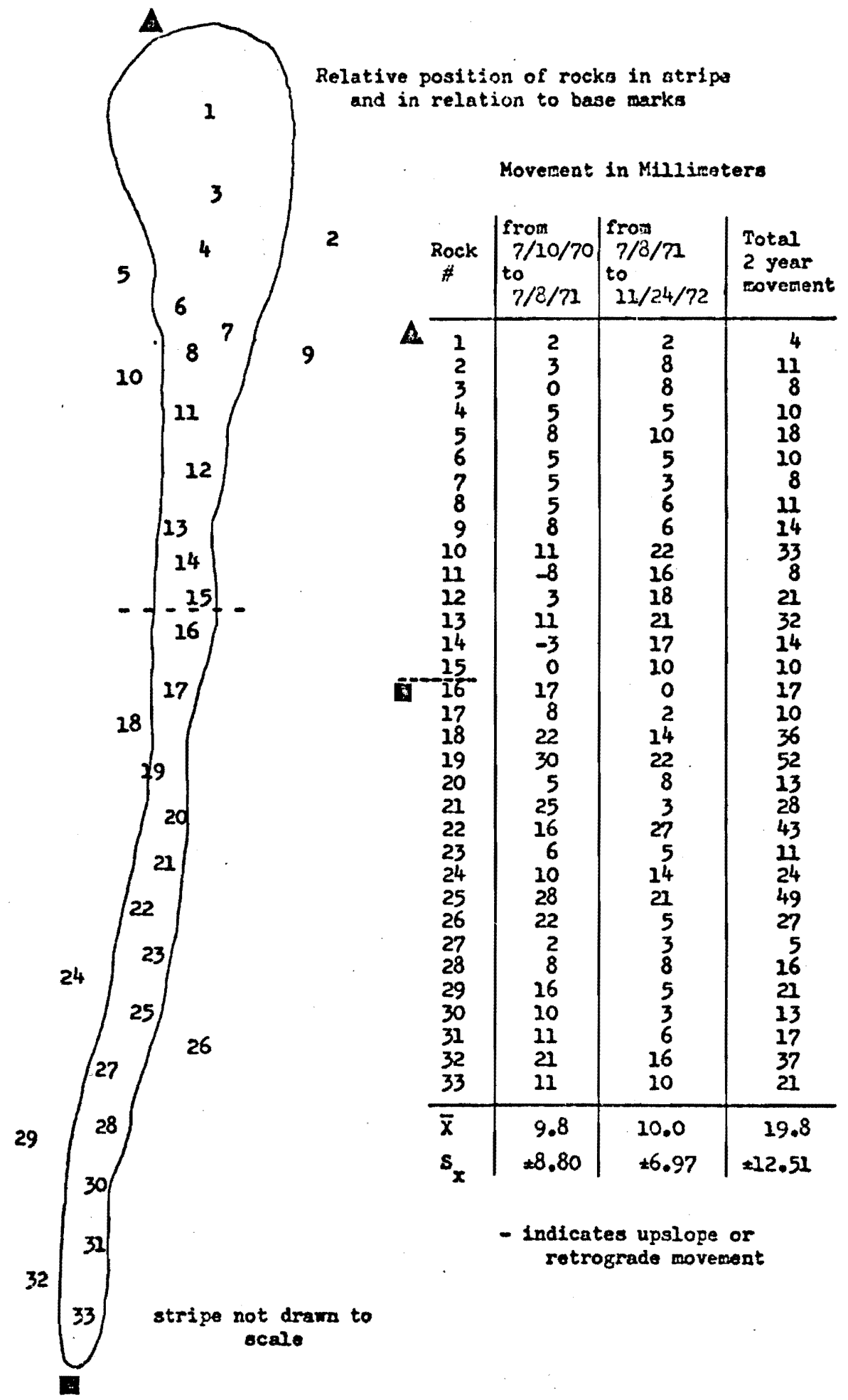

Figure 42. Painted rock measurements for stripe A. 


\section{Painted Rock Measurement Site B}

The second site is located on a $27^{\circ}$, convex slope that is oriented $\mathrm{S} 36^{\circ} \mathrm{E}$ (Fig. 41). Instability was evident everywhere and vegetation was poorly developed. The stone stripe is $41 \mathrm{~m}$ long and aligned in a $\mathrm{S} 33^{\circ} \mathrm{E}$ direction. One bedrock reference point, located at the stripe's head, was used to measure to 17 in situ rocks, although the last three rocks were measured to rock number 9 and the correct distance was computed by combining figures (Fig. 43). The amount of downslope movement ranged from 5 to $35 \mathrm{~mm}$ for individual rocks over the two-year period; mean movement for all the rocks was $10.7 \mathrm{~mm} / \mathrm{yr}$ (Fig. 43). Interstripe rocks moved downslope at an average rate of $12.2 \mathrm{~mm} / \mathrm{yr}$, while stripe rocks moved $10.1 \mathrm{~mm} / \mathrm{yr}$. This difference again is not statistically significant. The amount of movement increased with progress down the stripe or as the distance between the base mark and the measured rocks increased (Fig. 43). Perhaps this indicates greater movement at the stripe's toe, but it may also be due to greater measurement error.

\section{Painted Rock Measurement Site C}

The third site is located on a $24^{\circ}$, convex slope that faces $585^{\circ} \mathrm{W}$ (Fig. 41). Again vegetation was poorly developed and evidence of instability was found everywhere. The stripe is $21 \mathrm{~m}$ long and aligned in the same direction as the slope. A bedrock reference point was located at the head of the stripe and was used to measure to 14 in situ rocks throughout the stripe and interstripe areas (Fig. 44). Mean downslope movement for all the rocks was $10.9 \mathrm{~mm} / \mathrm{yr}$, although individual rock movements ranged from 6 to $32 \mathrm{~mm}$ over the two-year period (Fig. 44). 


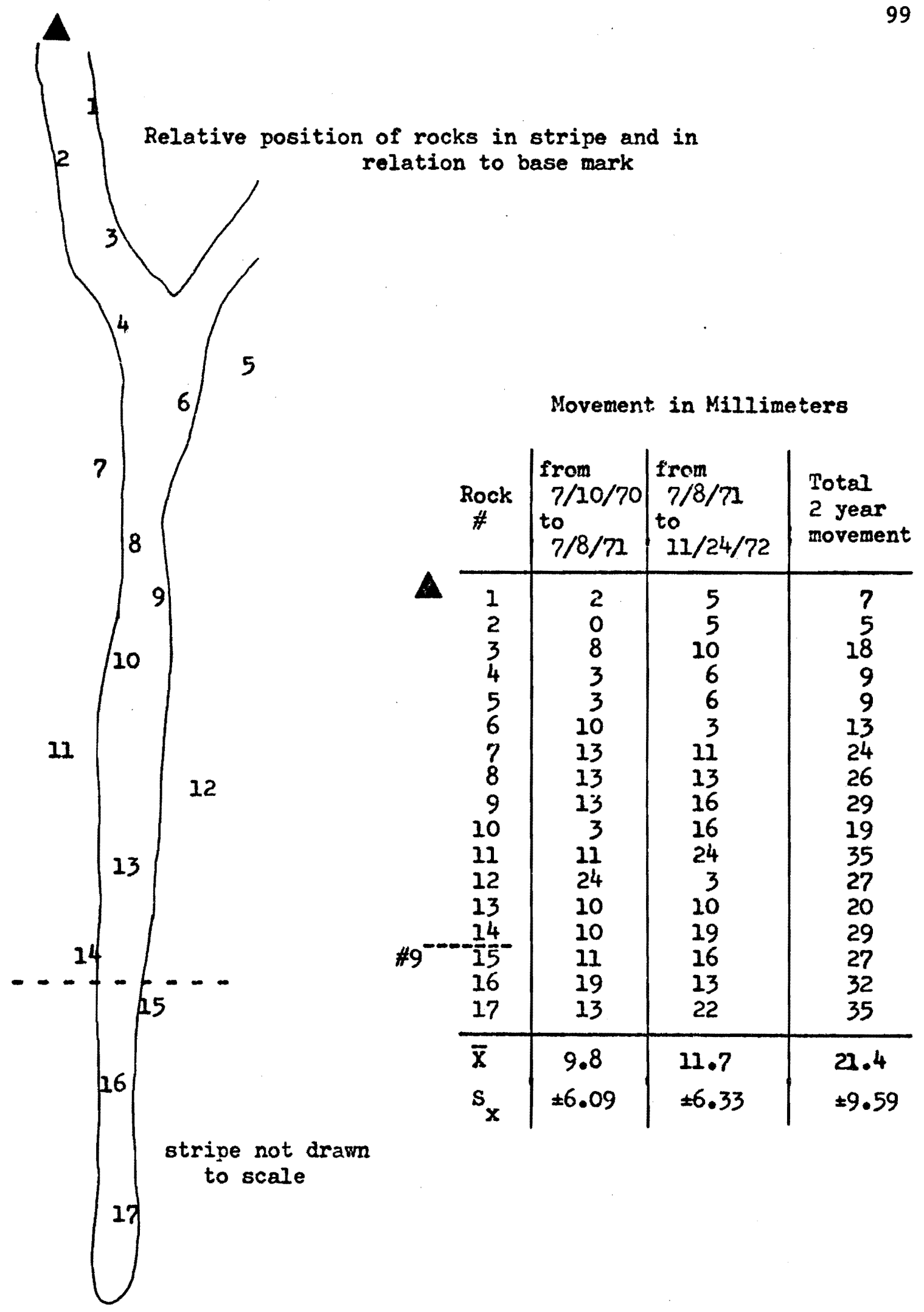

Figure 43. Painted rock measurements for stripe B. 


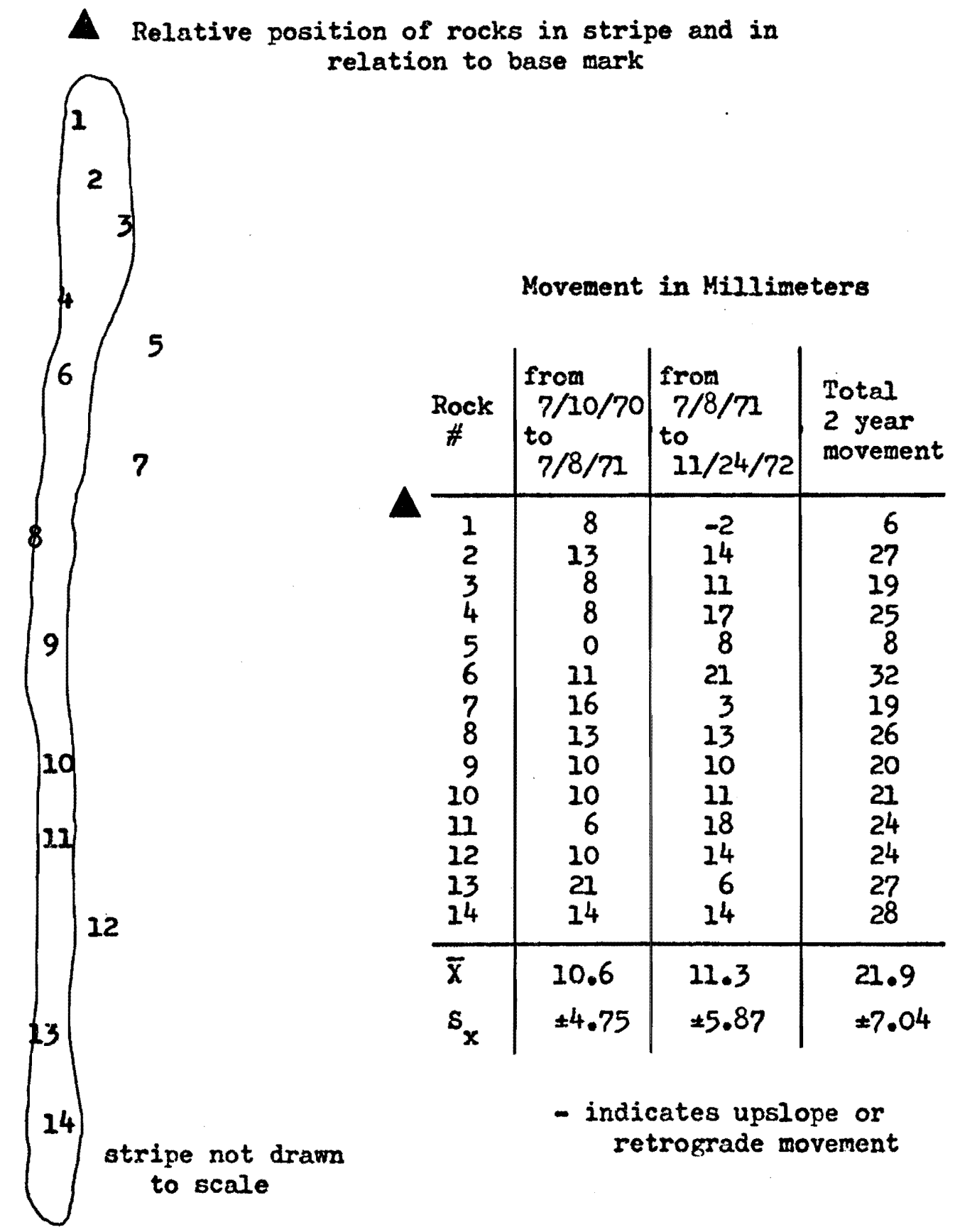

Figure 44. Painted rock measurements for stripe $\mathrm{C}$. 
The three interstripe rocks moved an average of $8.5 \mathrm{~mm} / \mathrm{yr}$, while the stripe rocks averaged $11.6 \mathrm{~mm} / \mathrm{yr}$. This was just the opposite of the other measurement sites where interstripe rocks were moving faster than stripe rocks, but because of the small interstripe sample, this difference is not statistically significant.

Painted Rock Measurement Sites $D, E, \& F$

These last three painted rock measurement sites are located at various points on a $30^{\circ}$, convex upper and relatively straight lower slope (Fig. 41). Vegetation was well developed on this slope and terracettes were abundant. Evidence of instability was everywhere, with upheaved soil, rocks, and vegetation. The slope faced $\mathrm{N} 60 \mathrm{~W}$ and was scarred with slump marks and a mud flow. All three measurement sites were located below basalt outcrops where reference points were established for measuring to a total of 15 in situ rocks (Fig. 45). Individual downslope rock movement varied from 0 to $170 \mathrm{~mm}$ over the two-year period for these sites (Fig. 45). The average downslope movement was $20.2 \mathrm{~mm} / \mathrm{yr}$, but if the one extremely high value $(170 \mathrm{~mm})$ is eliminated, the figure drops to a yearly average of $15.6 \mathrm{~mm}$.

The total results of these measurements indicate that average downslope movement in the stone stripes was $9.8 \mathrm{~mm} / \mathrm{yr}$; movement in the interstripe areas was $11.6 \mathrm{~mm} / \mathrm{yr}$. Although this difference is not statistically significant, it does give a relative indication of what is happening. Individual rock movements ranged from 3 to $52 \mathrm{~mm}$ during the two-year period. These rates of downslope movement are relatively high for a middle latitude site. They are accounted for by a combination of 
Relative position of rocks in relation to base mark
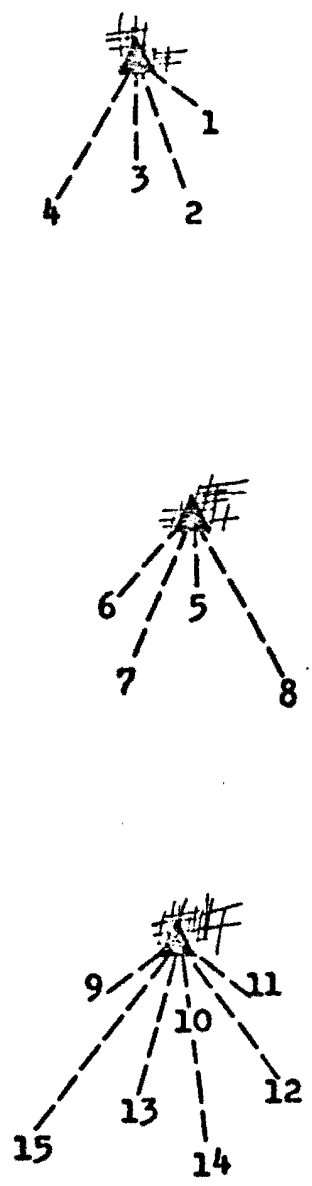

not drawn to scale

wi thout rock \#10
Movoment in Millimeters

\begin{tabular}{c|c|c|c}
$\begin{array}{c}\text { Rock } \\
\#\end{array}$ & $\begin{array}{c}\text { from } \\
7 / 10 / 70 \\
\text { to } \\
7 / 8 / 71\end{array}$ & $\begin{array}{l}\text { from } \\
7 / 8 / 71 \\
\text { to } \\
11 / 24 / 72\end{array}$ & $\begin{array}{l}\text { Total } \\
2 \text { year } \\
\text { movement }\end{array}$ \\
\hline 1 & 0 & 10 & 10 \\
2 & 13 & 38 & 51 \\
3 & 10 & 16 & 26 \\
4 & 13 & 36 & 49
\end{tabular}

\begin{tabular}{r|r|r|r}
5 & 19 & 5 & 24 \\
6 & 13 & 10 & 23 \\
7 & 6 & -2 & 4 \\
8 & 0 & 0 & 0
\end{tabular}

\begin{tabular}{c|c|c|c}
9 & 25 & 24 & 29 \\
10 & 95 & 75 & 170 \\
11 & 24 & 22 & 46 \\
12 & 24 & 13 & 37 \\
13 & 32 & 16 & 48 \\
14 & 25 & 29 & 54 \\
15 & 16 & 19 & 35 \\
\hline $\bar{x}$ & 21.0 & 20.7 & 40.4 \\
$s_{x}$ & \pm 21.66 & \pm 18.42 & \pm 33.36 \\
\hline $\bar{x}$ & 15.7 & 16.9 & 31.2 \\
$s_{x}$ & \pm 9.37 & \pm 10.85 & \pm 17.10
\end{tabular}

- indicates upsiope or retrograde movement

Figure 45. Painted rock measurements on the steep NW facing slope. 
factors, particularly steep gradients, high silt content in the soil, winter precipitation, and sparse vegetation. The general effectiveness of frost processes which are responsible for many of the specific features of instability found on slopes in north central Oregon, is perhaps the principal factor behind these impressive rates of mass wasting.

\section{IMPORTANCE OF PRESENT PROCESSES}

Frost action is currently an important process in the study area and evidence of it is found everywhere. Rocks are continually forced to the ground's surface, often forming a stone pavement (Fig. 46). These freshly exposed stones are often more angular and appear less weathered than the already exposed, lichen-covered rocks (Fig. 46). Frost heaving and thrusting, probably through the frost-push and frost-pul1 mechanisms discussed earlier, are the principal forces resulting in this concentration of rocks. Once the stones are at the ground's surface, other frost processes, such as needle ice and frost creep, come into play. During the cold months, ice crystals frequently form on the underside of surface and partially buried rocks (Fig. 47). These processes contribute to the overturning and downslope movement of rock fragments throughout the entire plateau. Frost-shattered rock and rubble are very common.

Soil extruded through weak places in the freezing crust forms frost boils (Fig. 46). These sma11, exposed patches of soil are subject to solifluction upon thawing and erosion with the coming of rain. During the summer, the frost boils appear flattened, with the soil 


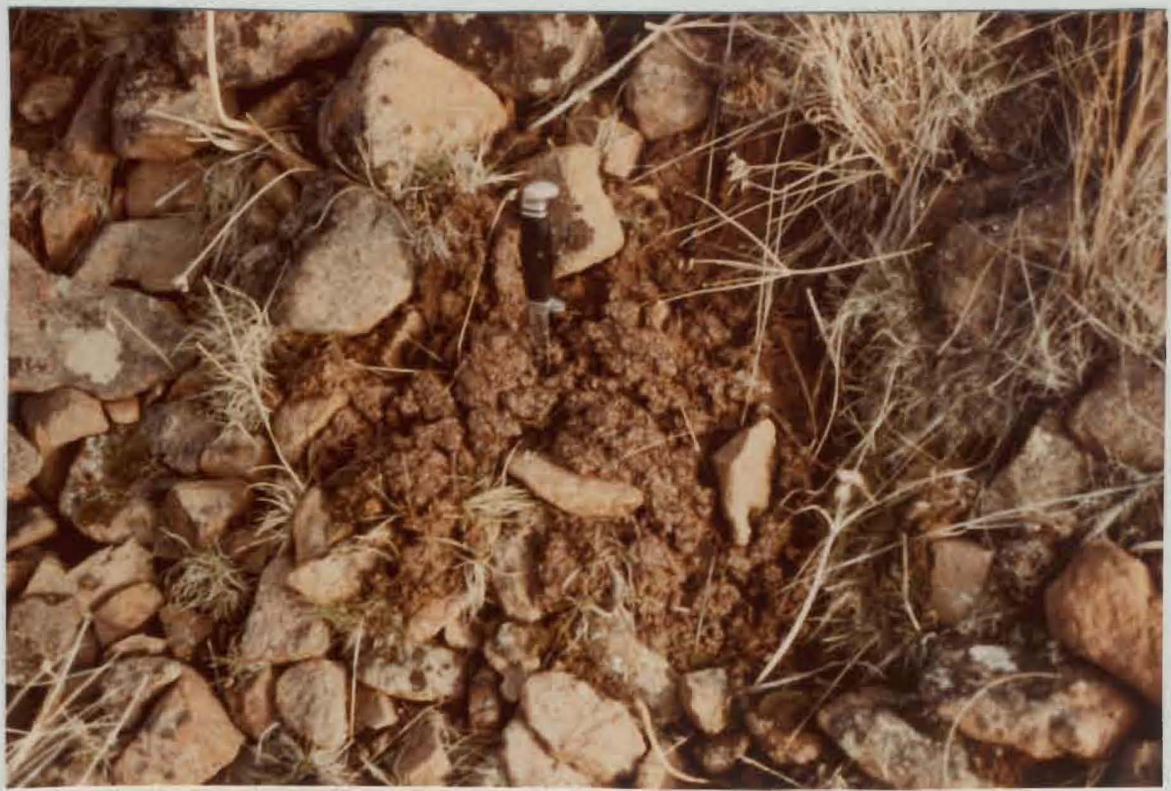

Figure 46. Frost heaved rocks on the Deschutes-Umatilla Plateau. The $20 \mathrm{~cm}$ knife provides scale.

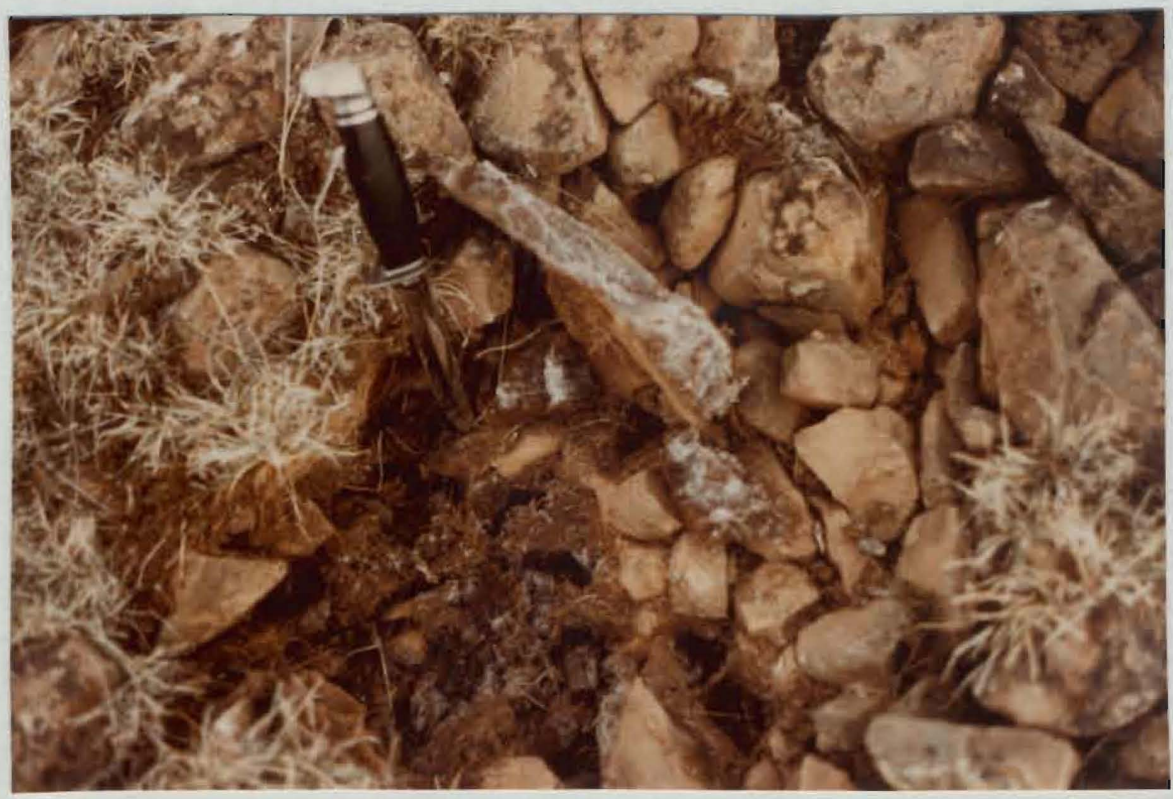

Figure 47. Ice crystals formed on the underside of rocks in a stone stripe. The $20 \mathrm{~cm}$ knife provides scale. 
washed away leaving the upheaved rocks behind (Fig. 48). When these features occur in areas of stone pavement, they form debris islands, or sorted circles, surrounded by rocks (Washburn 1956, p. 827).

Vegetation is constantly being lifted by frost, overturned, and buried (Fig. 49). In discussing the plant life of shallow soils in Washington's Columbia Basin, Daubenmire (1970, pp. 38-39) emphasizes the importance of frost processes in the following way:

.... Individual plants of Poa secunda are commonly lifted until they are perched on mounds approximately $5 \mathrm{~cm}$ by $5 \mathrm{~cm}$ tal1.

Until Artemisia rigida is several years old it too is subject to frost-lifting, and many young plants do not develop resistance to this force until about $15 \mathrm{~cm}$ of their tap root has been exposed by one or more episodes of frostlifting, which makes the bush appear like a miniature apple tree.

These same characteristics can be observed throughout the DeschutesUmatilla Plateau. Frost disturbance results in the actual burying of vegetation, so that the plants are oriented horizontally rather than vertically (Figs. $49 \& 50$ ). Roots are torn loose and separated from the soil by frost heaving (Figs. $49 \& 50$ ). Once exposed in this manner, the plant has little chance for survival. The disruption of vegetation is especially pronounced on steep slopes marked by terracettes (Fig. 50). Here the frost lifting is often so well developed that the treads are almost bare of vegetation, while the risers seem to be covered with overturned and dead vegetative matter (Fig. 50). Instability is a distinctive trait of the landscape in the study region, particularly in the interstripe and poorly vegetated areas.

Throughout the cold months, ice is found everywhere and the ground is frequently frozen solid. Frost penetration to depths of $76 \mathrm{~cm}$ and 


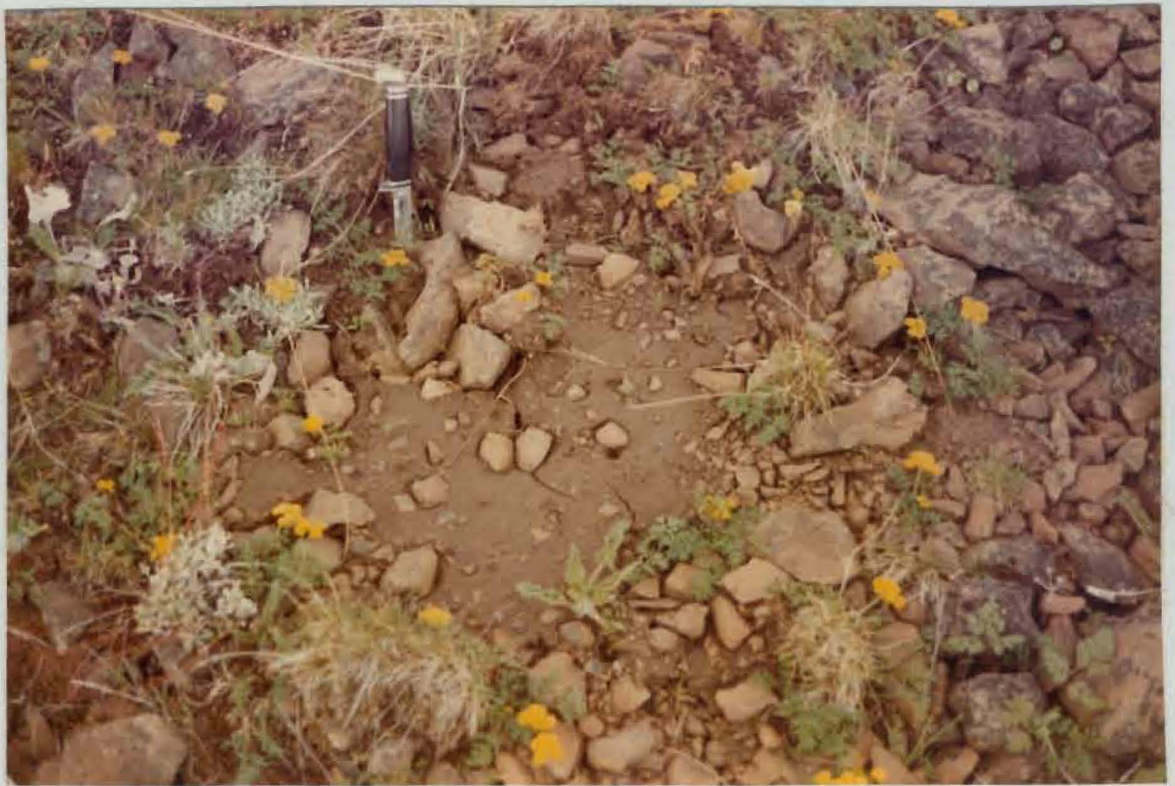

Figure 48. Flattened frost boil with recently exposed rocks. The $20 \mathrm{~cm}$ knife provides scale.

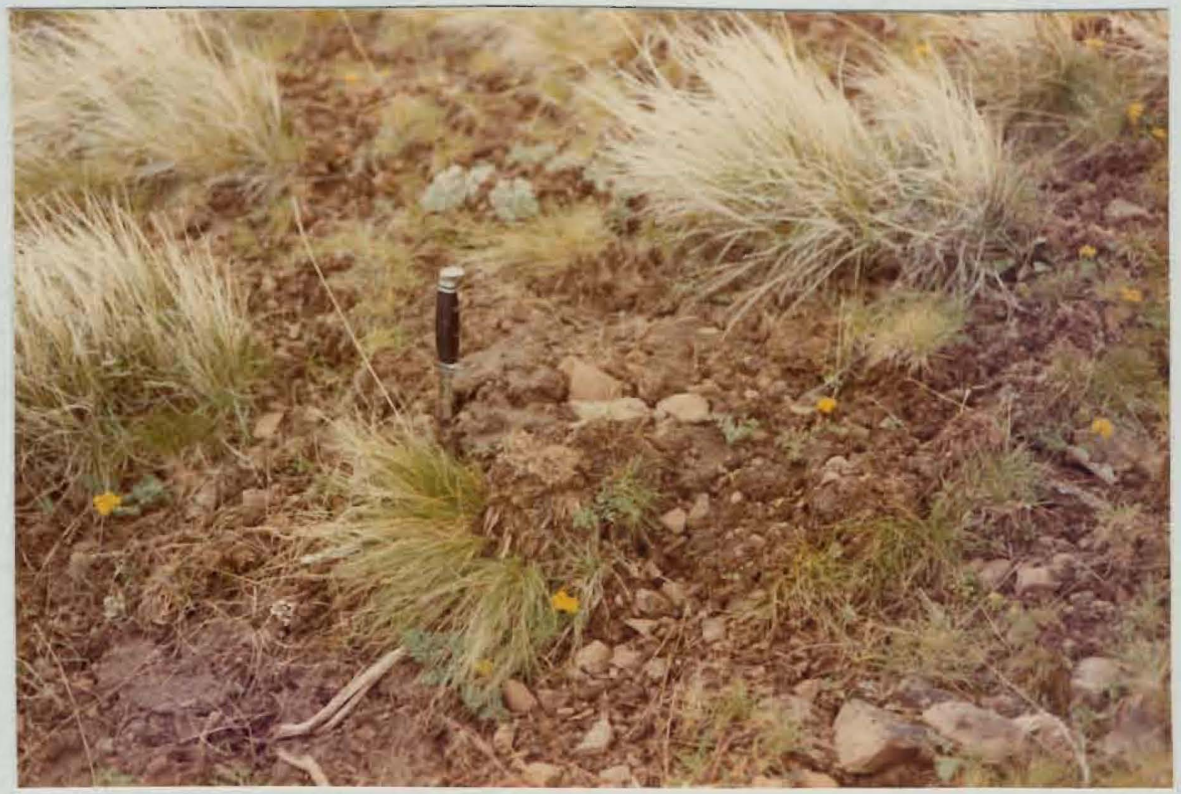

Figure 49. Frost heaved and overturned vegetation is a common site on the Deschutes-Umatilla Plateau. Downslope is to the lower lefthand corner of the picture. The $20 \mathrm{~cm}$ knife provides scale. 


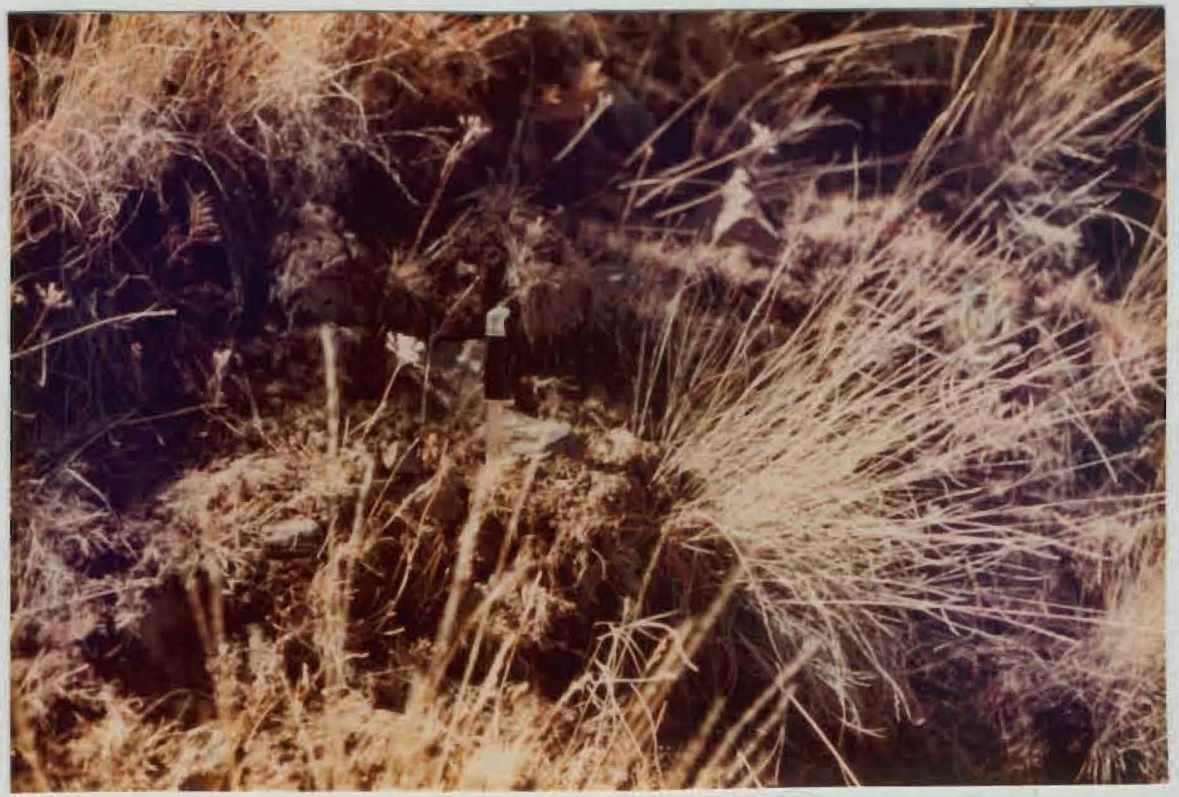

Figure 50. Frost heaved and buried vegetation on a steep, NW facing slope that is covered with terracettes. Downslope is to the right. The $20 \mathrm{~cm}$ knife provides scale.

the occurrence of ice lenses at depths of 61 to $74 \mathrm{~cm}$ were recorded by the Washington State Highway Department, at an elevation of about $866 \mathrm{~m}$, east of Ellensburg during the record-breaking cold of January 1950 (Sibley and Krashevski 1957, p. 6 in Kaatz 1959, p. 150). This, of course, represents abnormal conditions in an area that is located about $190 \mathrm{~km}$ north of the study area. However, conditions were probably similar in the research areas during that cold period and indicate the potential of frost penetration. Unfortunately, records are largely lacking for general frost conditions on the Deschutes-Umatilla Plateau. During fall, winter, and spring, when humidity and precipitation are highest, diumal freeze-thaw cycles occur with amazing frequency, particularly in areas of higher elevation (Table I \& Fig. 5). For example, The Dalles, with an elevation of $31 \mathrm{~m}$, averages 58 freeze-thaw days and 5 ice days annually; Kent, at an elevation of $825 \mathrm{~m}$, has a 
yearly mean of 123 frost alternation days and 16 ice days (Fig. 6). These figures greatly exceed the freeze-thaw cycles which occur in arctic and subarctic environments (Fraser 1959, pp. 44-45). The intensity, however, is considerably less. Nevertheless, such a large number of frost alternation days is very important geomorphologically. The flat, stone pavement areas generally have water standing on their surfaces during periods of thaw in winter and spring. This excessive wetness is conducive to the short duration and low penetration type of frost action that is important in the study area.

Other contemporary geomorphic processes which affect north central Oregon stone stripes include running water, wind action, wetting and drying of the soil, chemical and physical weathering, and mass wasting. The loose, friable surface soils which result from repeated frost action are easily removed by running water and wind. Such activity facilitates the concentration of rock particles at the ground's surface. Rain and snowmelt help to wash the soil from around the exposed rocks. In stripes, this washing of the soil would proceed down into the stripe, with the soil concentrating around the buried rocks and covering many of them (Fig. 19). In a semiarid environment where there isn't enough moisture to wash this soil away from the base of the stripe there would be a general infilling with the eventual burying of inactive stripes (Fig. 38). This appears to be happening to north central Oregon stone stripes, for evidence of their contemporary formation by running water is largely lacking.

Although wind action is significant year round in the study area, it is probably most effective during the summer when the soil is dry, 
parched, and easy to remove. During winter the ground is frequently either wet, frozen solid, or blanketed with a shallow snow cover. These conditions would help to protect the soil from wind action.

Repeated wetting and drying of surface soils seem to be more of a seasonal than diurnal process. The shallow, intermound soils are often saturated and sticky during periods of thaw in winter and during spring, but they are very dry in summer and early fall. The downslope movement of rock particles is facilitated by the saturated soil conditions in winter, although the overall effect is probably minor when compared to frost creep. Desiccation cracks are a common occurrence throughout the plateau in summer, but they are usually only small-scale features. Diurnal heating and cooling may possibly contribute significantly to the breaking apart of rock particles. Without actual observation, the results are hard to distinguish from frost wedging, since both processes render surface and partially buried rock into sharp angular fragments. Chemical weathering may also help in this disintegration process, but moisture is largely lacking when temperatures are adequate for chemical action. Where a stripe passes over disintegrating bedrock outcrops, rock particles are added to the stripe. The general mass wasting of such debris would help in the development and maintenance of the striped pattern.

That mass wasting is currently active in the study area has been demonstrated by the painted rock measurements and by the generally loose nature of the surface material. Measured rates of downslope movement indicate that interstripe areas are moving as fast and, more probably, 
slightly faster than the stripes, with the former averaging $11.6 \mathrm{~mm} / \mathrm{yr}$ and the latter $9.8 \mathrm{~mm} / \mathrm{yr}$. Individual rock movements ranged from 3 to $52 \mathrm{~mm}$ during the two-year measurement period (Figs. 42, 43, $44 \& 45$ ). Differential mass wasting, with the downslope stringing out of the trap mantle at the base of disintegrating bedrock, would produce a striped pattern if the material of the coarse stripes moved faster than that of the fine material (Washburn 1969, pp. 186-187). Where the opposite is true, the fine material would override and bury the slower moving coarse materia1 (Benedict 1970, p. 216). This seems to be the case in north centra1 Oregon, for the amount of downslope movement currently taking place in the stripes is not sufficient to maintain them, let alone form them entirely. 
CHAPTER VII

STONE STRIPE ORIGIN

Many stone stripes are polygenetic, not only in the sense of having been affected by different processes at different times in their morphological history, but also in the sense of being shaped by combinations of several types of formational processes simultaneously (Washburn 1956, PP. 859-860). Because of this complexity, the effects of individual geomorphic processes upon stone stripes are difficult to assess, especially when the formational processes may no longer be active because of changed environmental conditions. Nevertheless, a discussion of the formational processes which I feel shaped north central Oregon stone stripes is in order.

Several of the geomorphic processes currently operating on the Deschutes-Imatilla Plateau have been suggested as being responsible for the development of stone stripes. Needle ice, by causing differential movement of fines and stones, has been attributed an important role (Hay 1936, 1943; Gradwel1 1957). Since this process only applies to small-scale features usually less than $20 \mathrm{~cm}$ in width, it is highly improbable that such a mechanism could account adequately for stripes of the size under consideration. This is especially true in light of the strong vertical sorting to considerable depth that characterizes north central oregon stone stripes (Fig. 19). Since needle ice activity is principally a surface phenomenon, affecting only the top $0.5 \mathrm{~cm}$ or 
so of the soil, it is difficult to see how its growth could do more than redistribute material already near the ground's surface (Brockie 1968, p. 194). In the study area, its primary role is reinforcement of existing patterns.

Other frost processes, such as frost creep and frost heaving and thrusting, are important in the study area today. The impressive rates of surficial rock movement are due in large part to frost creep. Frost heave and thrust contribute significantly to the concentration of rock particles at the ground's surface in interstripe areas (Fig. 46). A11 these processes are recognized as important components in the development of stone stripes by frost action (Washburn 1956; Caine 1963; Brockie 1968). However, under the current intensity with which these processes operate on the plateau, only small-scale features with a width of $20 \mathrm{~cm}$ or less are likely to be formed.

Many geomorphic processes other than frost action have been mentioned as being important in the formation of stone stripes. Some of these processes are currently active in the study area and may be contributing to the development of stone stripes in north central oregon. Among the first to come to mind is surface erosion by water. Rillwork, with stones washing into rills and/or finer material becoming eluviated and leaving a lag concentrate, has been suggested as being responsible for the formation of some stone stripes (Brockie 1968, pp. 197-198; Washburn 1956, pp. 857-858; 1969, p. 178). But, here again, only sma11scale features with a maximun width of about $25 \mathrm{~cm}$ have been reported as originating from this process. Besides, many of the stone stripes in the study area are unbranched for long distances and do not reveal 
the dendritic pattern that is characteristic of this process (Washburn 1969, p. 178).

The eluviation of fines by rain and melt water has been cited by several researchers as being important in helping to define some types of large-scale stone stripes (Huxley and Odel1 1924, pp. 220-221; Sharp 1942, p. 296; Richmond 1949, p. 146). The water trickling along the base of the sorted stripe tends to wash out the fines from among the stones. Eventually, this results in greater sorting along the length of the stripe, thereby accentuating the difference between the stones of the stripe and the soil of the fine bands. In the study area, any drainage that is available is absorbed by the zone of soil which underlies the stone stripes (Figs. $14 \& 19$ ). Therefore, the effect of eluviation would be concentrated in a vertical direction down into the stripe rather than along the length of the stripe's base. This type of process would help to maintain the stripe's sorted appearance after initial formation, but it would not explain their origin entirely. Eventually, it would destroy inactive stripes through infilling, if the soil were not washed out along the base of the stripe. The strong vertical sorting exhibited by north central Oregon stone stripes is difficult to explain by a water erosion process (Fig. 19C), although some researchers felt that in this process, the stones at the base of the stripe will be wet longer than those at the surface of the stripe. Consequently, they suggested that the stones at the base of the stripe may be subject to much more chemical and physical weathering than those at the stripe's surface. This, in part, explains the vertical sorting (Huxley and Ode11 1924, p. 221; Miller, et al. 
1954, p. 217). The in situ weathered bedrock zone found throughout the study areas seems to support this idea; however, the weathered bedrock zone also occurs in the interstripe areas, so why did the stripes form where they did? Furthermore, it has not been determined whether the weathered zone predates the deposition of the loess, although this appears to be the case.

Even though surface erosion is one of the principal theories suggested as being responsible for stone stripes in the study area (LeConte 1874, 1877; Waters and Flagler 1924), there are severa1 unresolved difficulties with this explanation. How did the water become concentrated into such uniformly spaced channels? Why is there no buildup of fine material at the toe of the stripe? If surface erosion is the principal process responsible, why isn't there a uniform relationship between stripe depth and distance downslope? Perhaps the answer lies in the fact that the surface of the bedrock underlying the stripes is very jagged and uneven, with the depth to this bedrock varying greatly throughout the length of the stripe (Figs. $14 \& 30$ ). This would make it extremely difficult for water to move downslope along the bedrock surface. The soil under the stripes also would act to retard any downslope water movement at depth, through absorption. Although authors have pointed out that many stone stripes normally carry drainage, in many cases this is more a result than a cause of the stripes' pattern (Sharp 1942, p. 296; Richmond 1949, p. 146; Caine 1963, p. 178; Washburn 1969 , p. 180). I suspect that this is the situation in north central Oregon, for, in general, my studies have failed to reveal evidence for the erosional origin of the stripes. 
Numerous authors have mentioned that large stone stripes form along bedrock joints (Kunsky and Loucek 1956, pp. 345-347; Washburn 1969, p. 185). These writers suggest that eluviation of fines was probably important in emphasizing the sorted appearance of the stripes. Since no bedrock fissures or depressions were associated with the stripes investigated, this explanation does not provide an answer to the origin of stone stripes in the study region.

Another geomorphic process which has been credited with the formation of some large-scale stone stripes is differential mass wasting (Washburn 1969, pp. 186-188; Benedict 1970, p. 216). That mass wasting is presently active in the study area has been demonstrated by the painted rock measurements and by the unstable nature of the interstripe surface material. However, the presumed reduced magnitude of this mass wasting, along with stabilization of the stripes by vegetation encroachment, infilling, and 1ichen growth on the rocks, clearly indicate that stone stripes are not being actively formed by this, or any other process, currently. The downslope movement of rock material from disintegrating bedrock outcrops undoubtedly contributes to the development of many stone stripes in the study area. But the downslope movement of these rocks does not explain the strong vertical sorting, nor does it explain the stripes that are not associated with bedrock outcrops. On the basis of the preceeding analysis, north central Oregon stone stripes appear to be relic features. Although freshly overturned rock fragments, partially buried vegetation and shrubs, and painted rock measurements show some stripes to be active now, this activity functions primarily to reinforce existing patterns. Geomorphic processes currently 
operating on the Deschutes-Umatilla Plateau are not sufficient to satisfactorily explain the origin of these features. Extensive vegetation encroachment, infilling with soil, and pronounced moss and lichen growth on the rocks of stone stripes in the study area, indicate stability and support these conclusions.

Large-scale stone stripes comparable to those in the study area are largely restricted to cold regions (Davies $1969, \mathrm{p}, 23$ ). In fact, stone stripes reach their highest development in cold climates, particularly in areas underlain by permafrost. In such environments, they result from intense frost activity and at present this is the only process known which can produce vertically sorted features of the magnitude under consideration. This suggests that the stone stripes in north central Oregon are also cold climate features because of their size. But, you might ask, is there other evidence to support a periglacial origin for these features?

With the short duration and low penetration type of frost action currently an important geomorphic process on the Deschutes-Umatilla Pleateau, it is probable that the same processes were active in the past, only on a more intensive scale. By this I mean to infer, as does Fryxe11 (1964, p. 1), that freezing penetrated to significantly greater soil depths than at present; a longer annual duration of such conditions prevailed; and a longer duration of total annual frost conditions involving alternate freezing and thawing, due either to diurnal temperature fluctuations or to cyclic weather changes, occurred during a former cooler and moister climatic period. Permafrost conditions were regarded as possible by $\operatorname{Kaatz}(1959, \mathrm{p} .152$ ), but no field evidence is available to support this contention. 
In general, pollen records from the area indicate that a climate cooler and moister than at present persisted until about 15,000 years ago (Hansen 1946, p. 729; Huesser 1960, 1965). This coincides with the time when alpine glaciers and the Cordilleran Ice Sheet were at their maximum (F1int 1971, p. 463) (Fig. 51). With the study area located about 50 to $75 \mathrm{~km}$ east of the Cascade Mountains and 250 to $300 \mathrm{~km}$ south of the Cordilleran Glacier Complex boundary, a temperature drop of a few degrees seems plausible (Flint 1971, pp. 3-4) (Fig. 51). Coupled with this was the increased moisture during the period, as reflected by the extensive development of pluvial lakes in the Great Basin (Hansen 1946, pp. 730-731; Morrison 1965) (Fig. 51). This moisture factor may be even more important than the temperature factor. For example, Williams (1961) has pointed out that large-scale patterned ground is well developed in northern Norway but virtually absent in Ottawa, Canada, even though both regions experience similar frost index values and equally severe winters. Thus, a maritime climate with abundant moisture is more conducive to the formation of large-scale ground patterns than a continental climate. This may also help explain the general absence of patterned ground in the midwest of the United States, since such features do occur in the eastern and western sections of the continent. The increased moisture during pluvial conditions probably would have enhanced frost activity greatly on the Deschutes-Umatilla Plateau. This would be particularly so since the moisture would have been, most 1ikely, concentrated in the cooler months, just as today (Table I). When these conditions are combined with the extreme frost susceptibility of silt (the principal soil component in north central Oregon), the 


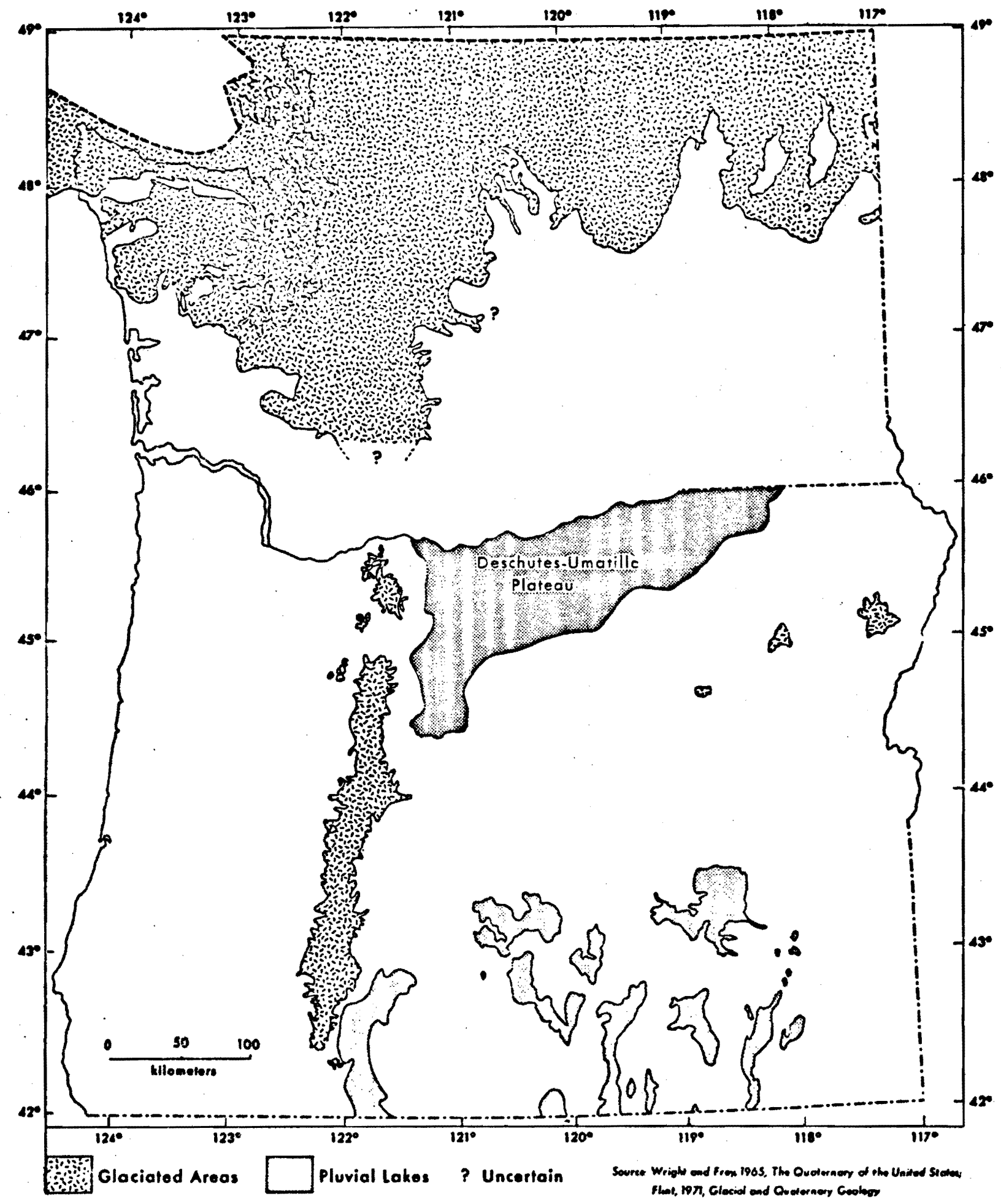

Figure 51. Maximum extent of glaciation and pluvial lakes in relation to the study area during the Quaternary. 
sparse vegetative cover, the shallow, largely impermeable basalt bedrock, and the general absence of snow in winter (although it was most likely greater during the period we are discussing), the stage is set for considerably greater frost activity than is presently found.

Other evidence which lends credence to a periglacial origin for these features are the additional types of patterned ground frequently found in association with stone stripes. These include sorted circles, nets, and polygons which normally occur on relatively horizontal ground, while the stripes occupy the slopes. Such large-scale forms are abundant on the Deschutes-Umatilla Plateau and again the magnitude of these features suggests a cold climate origin (Flint 1971, p. 280). The ubiquitous soil mounds have also been regarded by several authors as periglacial features (Kaatz 1959; Malde 1961, 1964). Their close association with the level surface forms of patterned ground has prompted these researches to hypothesize that their origin is intimately related. Such may or may not be the case, but the periglacial origin of these features seems to be the most acceptable explanation.

It has been pointed out that slopes subjected to periglacial mass wasting processes are often marked by terraces and terracettes (Tricart 1970, pp. 98-99). Terracettes are also well developed in north central Oregon. Whether they existed before the introduction of cattle is not clear; however, since several people have argued for an anthropogenic origin (Rahm 1962). The geomorphic processes presently operating in these terracette areas would seem to contribute significantly to their development (Fig. 58). 
Although talus slopes can occur in all climates, they are, perhaps, particularly evident under periglacial conditions where strong frost action produces an abundance of source material (Price 1972, p. 38). These features are present throughout the study area. They normally appear fairly stable, with vegetation encroachment and lichen development quite pronounced. The same is true for a majority of the stone stripes I have observed. Again the inference is that the climate was formerly more severe and that the present ameliorated conditions have allowed the stabilization of these forms (Smith 1949b, pp. 199-203; Richmond, et a1. 1965, p. 240).

During such a cooler, moister period, frozen ground extended to a greater depth and persisted for a longer portion of the year than at present. The relatively impermeable and ill-drained basalt bedrock had virtually the same effect as permafrost in restricting subdrainage. Intense frost action is favored by water-saturated soil at, or above, such an impermeable zone (Hopkins, et al. 1955, p. 142). Since stone stripes generally do not occur where the soil mantle is more than $1 \mathrm{~m}$ deep, this depth is interpreted to represent the general level of frost penetration in the soil. With frost penetration to this depth occurring today under abnomal conditions in the study area, it very well may have been a common occurrence during the glacial maximum.

Under such conditions, frequent, intense freeze and thaw cycles would rapidly break down the basalt bedrock and rock debris. Frost heaving and thrusting would segregate the rock fragments from the finer material, creating a sorted pattern that would be extended downslope by mass wasting. The increased moisture available during this time would 
also contribute to greater rates of downslope movement. The high frequency of frost alternation cycles would contribute to the segregation of larger rock particles from the smaller ones within the stripe itself, thus creating the strong vertical sorting so characteristic of north central Oregon stone stripes.

The extensive development of stone stripes in north central Oregon is thought to provide evidence of a former periglacial climate. Documentation of other periglacial landforms in this region, no matter how hard to find or risky to interpret, would undoubtedly increase our understanding of the role past climate played in shaping the landscape of this area. Incorporated with physiographic, stratigraphic, paleontologic, and pedologic studies, periglacial features would acquire chronologic significance and would help to define further the rates of geomorphic change. 
CHAPTER VIII

RECOMMENDATIONS FOR FURTHER STUDY

One of the problems of investigating a subject that has not been studied in detail before is that frequently more questions are uncovered than answered. Such is the case with my study of north central Oregon stone stripes. There are still a number of inquiries that can be made with regard to the environmental parameters surrounding these features and the processes operating on them. The following list is by no means complete, but points to several areas of possible research.

1. A more detailed investigation of current mass wasting rates and processes in the study area is needed. Information on how these rates and processes vary from season to season, with respect to slope angle and orientation, and under different vegetation and soil conditions, would be useful in evaluating how important contemporary geomorphic activity is in shaping the landscape.

2. The close association of mounds and patterned ground is still an enigma. Opinions differ greatly as to whether the sorted ground features developed before, during, or after the mounds (Kaatz 1959, p. 154; Brunnschweiler 1962, pp. 22-23). The role, if any, that each played in the development of the other is unclear. Perhaps an analysis of the weathered bedrock zone, 
which occurs throughout the plateau underlying all these features, would shed some light on this subject. Is this weathered zone contemporary or fossil?

3. The exact origin and time of deposition of the loess has yet to be determined in the study area. It is still uncertain as to why mounds and patterned ground do not occur in the area adjacent to the Columbia River (Fig. 39). It has been speculated that soil depth is the primary reason, but there may be much more to this question than depth of former frost penetration (Kaatz 1959, p. 153). Possibly the loess in this region is more recent than the loess in which the mounds and patterned ground formed (Fryxe11 1964, pp. 10-11).

4. The whole problem of a possible late Wisconsin climate that was cooler and/or moister than at present should be systematically looked at, on a regional basis. Documenting the distribution of the evidence which could be used to support a former periglacial climate would enhance our understanding of past environmental conditions and the extent to which they were important in shaping the contemporary landscape. 


\section{REFERENCES CITED}

Baldwin, E. M., 1964, Geology of Oregon, second edition, Edwards Brothers, Inc., Ann Arbor, Michigan, 165 pages.

Benedict, J. B., 1970, "Downslope Soil Movement in a Colorado Alpine Region: Rates, Processes, and Climatic Significance," Arctic and Alpine Research, Vol. 2, No. 3, pp. 165 226.

Beskow, G., 1947, Soil Freezing and Frost Heaving with Special Application to Roads and Railroads, (Translated by J. 0. Osterberg), Northwestern University Technological Institute, 145 pages.

Bowley, W. W. and M. D. Burghardt, 1971, "Thermodynamics and Stones," American Geophysical Union Transactions, Vo1. 52, No. 1, pp. 4-7.

Brockie, W. J., 1968, "A Contribution to the Study of Frozen Ground Phenomena - Preliminary Investigations into a Form of Miniature Stone Stripes in East Otago," New Zealand Geographic Society, 5th Proceedings, pp. 191-201.

Brunnschweiler, D., 1962, "The Periglacial Realm in North America During the Wisconsin Glaciation," Biuletyn Peryglacjalny, Vol. 11, pp. 15-27.

Bryan, K., 1928, "Glacial Climate in Non-glaciated Regions," American Journal of Science, Vol. 16, pp. 162-164.

Caine, T. N., 1963, "The Origin of Sorted Stripes in the Lake District, Northern England," Geografiska Annaler, Vo1. 45, No. 3, pp. 172179.

Clark, G. M., 1968, "Sorted Patterned Ground: New Appalachian Localities South of the Glacial Border," Science, Vo1. 161, pp. 355-356.

Corte, A. E., 1962, "The Frost Behavior of Soils: Laboratory and Field Data for a New Concept, Part II. Horizontal Sorting," United States Army Cold Regions Research and Engineering Laboratory Research Report 85 , Part II, 20 pages.

Daubenmire, R. F., 1959, Plants and Environment, second edition. John Wiley, Inc., New York, N. Y., 422 pages.

, 1970, "Steppe Vegetation of Washington," Washington Agricultural Experiment Station Technical Bulletin 62, Washington State University, 131 pages. 
Davies, J. L., 1969, Landforms of Cold Climates, The M. I. T. Press, Cambridge, Mass., 200 pages.

Denny, C. S., 1940, "Stone Rings on New Hampshire Mountains," American Journa1 of Science, Vol. 238, pp. 432-438.

Dicken, S. N., 1965, Oregon Geography, fourth edition, Edwards Brothers, Inc., Ann Arbor, Michigan, 147 pages.

Dyksterhuis, E. L., G. H. Simonson, J. A. Norgren, and R. E. Hosler, 1969, "John Day Drainage Basin, General Soil Map Report with Irrigable Areas," Oregon's Long-Range Requirements for Water, Appendix I-6, Oregon State Water Resources Board, 101 pages.

Dzulynski, S., 1963, "Polygonal Structures in Experiments and their Bearing on some 'Periglacial Phenomena'," Bulletin De L'Academie Polonaise Des Sciences, Vo1. 11, No. 3, pp. 145-150.

Embleton, C. and C.A. M. King, 1968, Glacial and Periglacial Geomorphology, Edward Arnold Ltd., London, 608 pages.

Fairbridge, R. W. (ed.), 1968, The Encyclopedia of Geomorphology, Reinhold Book Corp., New York, N. Y., 1295 pages.

F1int, R. F., 1971, Glacia1 and Quaternary Geology, John Wiley, Inc., New York, N. Y., 892 pages.

Fosberg, M. A., 1965, "Characteristics and Genesis of Patterned Ground in Wisconsin Time in a Chestnut Soil Zone of Southern Idaho," Soil Science, Vo1. 99, No. 1, pp. 30-37.

Franklin, J. F. and C. T. Dyrness, 1969, "Vegetation of Oregon and Washington," U. S. D. A. Forest Service Research Faper PNW-80, Pacific Northwest Forest and Range Experiment Station, Portland, Oregon, 216 pages.

Fraser, J. K., 1959, "Freeze-Thaw Frequencies and Mechanical Weathering in Canada," Arctic, Vol. 12, pp. 40-53.

Freeman, 0. W., 1926, "Scabland Mounds of Eastern Washington," Science, Vol. $64, \mathrm{pp} .450-451$.

, 1932, "Origin and Economic Value of Scabland Mounds of Eastern Washington," Northwest Science, Vo1. 6, pp. 37-40.

, J. D. Forrester, and R. L. Lupher, 1945, "Physiographic Divisions of the Columbia Intermontane Province," Association of American Geographers, Annals, Vol. 35, pp. 53-75. 
Fryxe11, R., 1964, "Late Wisconsin Age of Mounds on the Columbia Plateau of Eastern Washington," unpublished paper, Laboratory of Anthropology, Washington State University, 16 pages.

Gradwe11, M. W., 1957, "Patterned Ground at a High Country Station," New Zealand Journal of Science and Technology, Sec. B, Vol. 38, pp. 793-806.

Green, G. L., G. H. Simonson, and J. A. Norgren, 1969, "Hood River Drainage Basin, General Soil Map Report with Irrigable Areas," Oregon's Long-Range Requirements for Water, Appendix I-4, Oregon State Water Resources Board, 58 pages.

Hansen, H. P., 1946, "Postglacial Forest Succession and Climate in the Oregon Cascades," American Journal of Science, Vol. 244, No. 10, pp. 710-734.

Hay, T., 1936, "Stone Stripes," Geographical Journa1, Vo1. 87, pp. 4750 .

, 1943, "Notes on Glacial Erosion and Stone Stripes," Geographical Journal, Vo1. 102, pp. 13-20.

Heusser, C. J., 1960, Late-P1eistocene Environments of North Pacific North America, American Geographical Suciety, Special Publication No. 35,308 pages.

, 1965, "A Pleistocene Phytogeographic Sketch of the Pacific Northwest and Alaska," pp. 469-483, in H. E. Wright, Jr. and D. G. Frey (eds.), The Quaternary of the United States, Princeton University Press, New Jersey, 922 pages.

Hopkins, D. M., et a1., 1955, "Permafrost and Ground Water in Alaska," U. S. Geological Survey Professional Paper 264-F, pp. 113-145.

Hunt, C. B. and A. L. Washburn, 1966, "Patterned Ground," U. S. Geological Survey Professional Paper No. 494-B, pp. B104-B133.

Huxley, J. S, and N. E. Ode11, 1924, "Notes on Surface Markings in Spitsbergen," Geographical Journa1, Vo1. 63, pp. 207-229.

Kaatz, M. R., 1959, "Patterned Ground in Central Washington: A Preliminary Report," Northwest Science, Vo1. 33, No. 4, pp. 145156.

Knechte1, M. M., 1952, "Pimpled Plains of Eastern Oklahoma," Bulletin, Geologica1 Society of America, Vo1. 63, pp. 689-699.

Kunsky, J. and D. Loucek, 1956, "Stone Stripes and Thufurs in the Krkonose," Biuletyn Peryglacjalny, Vol. 4, pp. 345-349. 
LeConte, J., 1874, "On the Great Lava-flood of the Northwest; and on the Structure and Age of the Cascade Mountains," American Journa1 of Science, 3rd series, Vol. 7, pp. 167-180, 259-261, 362-367.

, 1877, "Hog Wallows or Prairie Mounds (of California and Oregon)," Nature, Vol. 15, pp. 530-531.

Iundqvist, G., 1949, "The Orientation of Block Material in Certain Species of Flow Earth," Geografiska Annaler, Vo1. 31, pp. 235-247.

Malde, H. E., 1961, "Patterned Ground of Possible Solifluction Origin at Low Altitude in the Western Snake River Plain, Idaho," U. S. Geological Survey Professional Paper No. 424-B, pp. B170-B173.

, 1964, "Patterned Ground in the Western Snake River Plain, Idaho, and Its Possible Cold-Climate Origin," Bulletin, Geological Society of America, Vo1. 75, pp. 191-208.

Meinig, D., 1968, The Great Columbia Plain, University of Washington Press, Seattle, Washington, 576 pages.

Miller, R., R. Common, and R. W. Galloway, 1954, "Stone Stripes and Other Surface Features of Tinto Hill," Geographical Journal, Vo1. 120, pp. 216-219.

Morrison, R. B., 1965, "Quaternary Geology of the Great Basin," pp. 265285 , in H. E. Wright, Jr. and D. G. Frey (eds.), The Quaternary of the United States, Princeton University Press, New Jersey, 922 pages.

Newcomb, R. C., 1967, "The Dalles-Umatilla Syncline, Oregon and Washington," U. S. Geologica1 Survey Professional Paper No. 575-B, pp. B88-B93.

, 1969, "Geology of the Deschutes-Umatilla Plateau," pp. 60-66, in A. E. Weissenborn (ed.), Mineral and Water Resources of Oregon, Bulletin 64, State of Oregon Department of Geology and Mineral Industries, 462 pages.

Norgren, J. A. and G. H. Simonson, 1969, "Umatilla Drainage Basin, General Soil Map Report with Irrigable Areas," Oregon's Long-Range Requirements for Water, Appendix I-7, Oregon State Water Resources Board, 73 pages.

, et a1., 1969, "Deschutes Drainage Basin, Genera1 Soil Map Report with Irrigable Areas," Oregon's Long-Range Requirements for Water, Appendix I-5, Oregon State Water Resources Board, 116 pages.

01msted, R. K., 1963, "Silt Mounds of Missoula Flood Surfaces," Bulletin, Geologica1 Society of America, Vol. 74, pp. 47-54. 
Pacific Northwest River Basins Commission, 1969, Climatological Handbook, Columbia Basin States, Temperature, Vol. 1, Parts A and B, 540 pages; Precipitation, Vol. 2, 262 pages.

Piper, C. V., 1905, "The Basalt Mounds of the Columbia Plateau," Science, Vo1. 21, pp. 824-825.

Price, L. W., 1972, The Periglacial Environment, Permafrost, and Man, Commission on College Geography, Resource Paper No. 14, Association of American Geographers, Washington, D. C., 88 pages.

and C. S. Alexander, 1971, "Methods of Measuring Mass Wasting; Review and Critique," Association of American Geographers, Proceedings, Vo1. 3, pp. 135-139.

Rahm, D. A., 1962, "The Terracette Problem," Northwest Science, Vo1. 36, No. 3, pp. $65-80$.

Richmond, G. M., 1949, "Stone Nets, Stone Stripes, and Soil Stripes in the Wind River Mountains, Wyoming," Journal of Geology, Vo1. 57, pp. 143-153.

, et a1., 1965, "The Cordilleran Ice Sheet of the Northern Rocky Mountains, and Related Quaternary History of the Columbia Plateau," pp. 231-242, in H. E. Wright Jr. and D. G. Frey (eds.), The Quaternary of the United States, Princeton University Press, New Jersey, 922 pages.

Sharp, R. P., 1942, "Soil Structures in the St. Elias Range, Yukon Territory," Journal of Geomorphology, Vol. 5, pp. 274-301.

Sharpe, C. F. S., 1938, Landslides and Related Phenomena, Columbia University Press, New York, 137 pages.

Sigafoos, R. S. and D. M. Hopkins, 1952, "Soil Instability on Slopes in Regions of Perennially-Frozen Ground," pp. 176-192, in Frost Action in Soils: A Symposium, National Academy of Sciences, National Research Council, Highway Research Board Special Report, No. 2, 385 pages.

Smith, H. T. U., 1949a, "Physical Effects of Pleistocene Climatic Changes in Non-Glaciated Areas: Eolian Phenomena, Frost Action, and Stream Terracing," Bulletin, Geological Society of America, Vo1. 60, pp. 1485-1514.

, 1949b, "Periglacia1. Features in the Driftless Area of Southern Wisconsin," Journal of Geology, Vo1. 57, pp. 196-215.

, 1962, "Periglacial Frost Features and Related Phenomena in the United States," Biuletyn Peryglacjalny, Vo1. 11, pp. 325-342. 
Strelkov, S. A., 1968, "Tundra Landscape," pp. 1176-1179, in R. W. Fairbridge (ed.), The Encyclopedia of Geomorphology, Reinhold Book Corp., New York, N. Y., 1295 pages.

Taber, S., 1929, "Frost Heaving," Journal of Geology, Vo1. 37, pp. 428461.

, 1930, "The Mechanics of Frost Heaving," Journal of Geology, Vo1. 38, pp. 303-317.

, 1943, "Perennially Frozen Ground in Alaska: Its Origin and History," Bulletin, Geologica1 Society of America, Vo1. 54, pp. 1433-1548.

Tricart, J., 1970, Geonorphology of Cold Environments, (Translated by Edward Watson), St. Martin's Press, New York, N. Y., 320 pages.

Tro11, C., 1959, "Strukturboden, Solifluktion und Frostklimate der Erde," (Translated by H. E. Wright, Jr. and associates), U. S. Army Snow, Ice and Permafrost Research Establishment, Translation 43, Corps of Engineers, Wilmette, Illinois, 121 pages.

Washburn, A. L., 1956, "Classification of Patterned Ground and Review of Suggested Origins," Bulletin, Geological Society of America, Vol. 67, No. 7, pp. 823-866.

, 1969, "Weathering, Frost Action, and Patterned Ground in the Mesters Vig District, Northeast Greenland," Meddelelser om Gronland, Bd. 176, No. 4, 303 pages.

1973, Periglacial Processes and Environments (pre copy), Edward Arnold Ltd., London (In press).

Waters, A. C. and C. W. Flagler, 1929, "Origin of the Sma11 Mounds on the Columbia River Plateau," American Journal of Science, Vo1. 18, pp. 209-224.

Weide, D. L., 1972, Curator, Geology Museum, University of California, Los Angeles, personal communication.

Williams, P. J., 1961, "Climatic Factors Controlling the Distribution of Certain Frozen Ground Phenomena," Geografiska Annaler, Vo1. 43, Nos. 3-4, pp. 339-347.

Wright, H. E., Jr. and D. G. Frey (eds.), 1965, The Quaternary of the United States, Princeton University Press, New Jersey, 922 pages. 


\section{APPENDIX}

\section{STONE STRIPE CHECK LIST}

A check list was prepared so that the collection of detailed information on the structure, composition, and occurrence of stone stripes for later analysis would be consistent and orderly. The check list was developed on the basis of field reconnaissance in the research area and a literature review. 
SCRTED STRIFE CHECK LIET

Region \#

Stripe

1. Location: T R sec

2. Slope angle (degrees)

3. Slope orientation (degrees)

4. Stripe orientation (derseee)

5. Length of stripe (m)

6. Width of stripe (m)

upper lower

7. Width of interstripe area $(x)$

upper lower

8. Concentration of material

head

toe center junction

9. Rock type

(bring back I rock from each strige)

10. Compositicn of interstripe area

11. Rock angularity:

sharp Hijad Center Toe
medium
rounded $\longrightarrow-$

12. Stripe surface:

are rocks on edige

are rociks parallel to slope

where are largest rocks found

is there spacing of larger rocks throughout length of strip sketch of slope cross-section (includins bedrock)

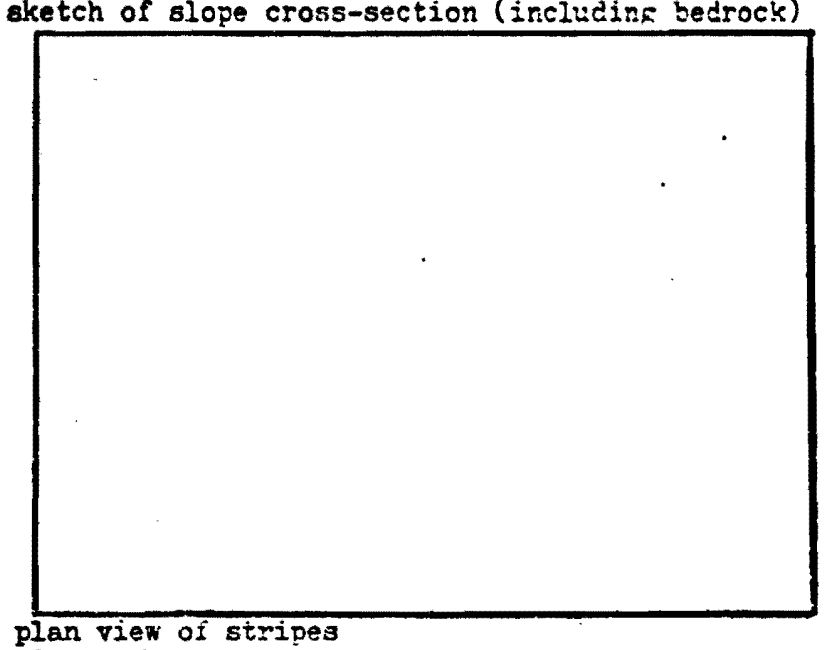


13. Surface horizontal cross-section:

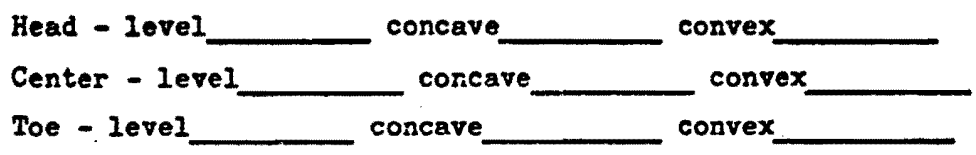

14. Relationship to other forms of patterned ground

15. Ecological relationships

16. Evidence of water flow

17. Evidence of activity or inactivity

18. Comwerts on overail appearance

Vertical Cross-section Information:

1. Depth of stripe $(\mathrm{cm})$ : head center

2. Depth to bedrock below stripe $(\mathrm{cm})$ : head

center
toent to stripe (cm
surface
middle
base
center head ipe area ad jac toe

4. Shape of vertical cross-section $(\mathrm{cm})$ :

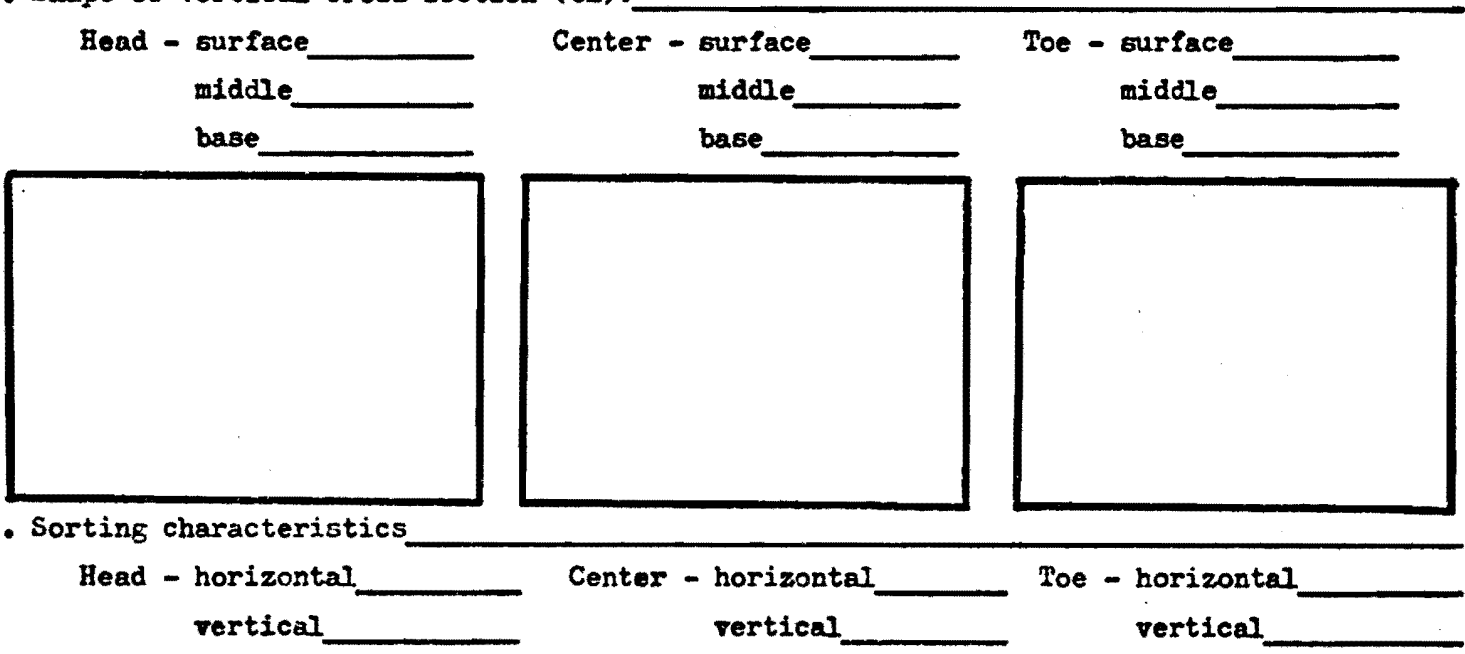

6. Does stripe extend under or into adjacent interstripe material

is regetation covering any portion of stripe how does covered section differ frow uncovered part

7. Heathering characteristics throughout cross-section:

\begin{tabular}{lll}
\hline Head: & Center: & Toe: \\
surface & surface & ourface \\
middle & middle & middle \\
base & base & base. \\
\hline
\end{tabular}




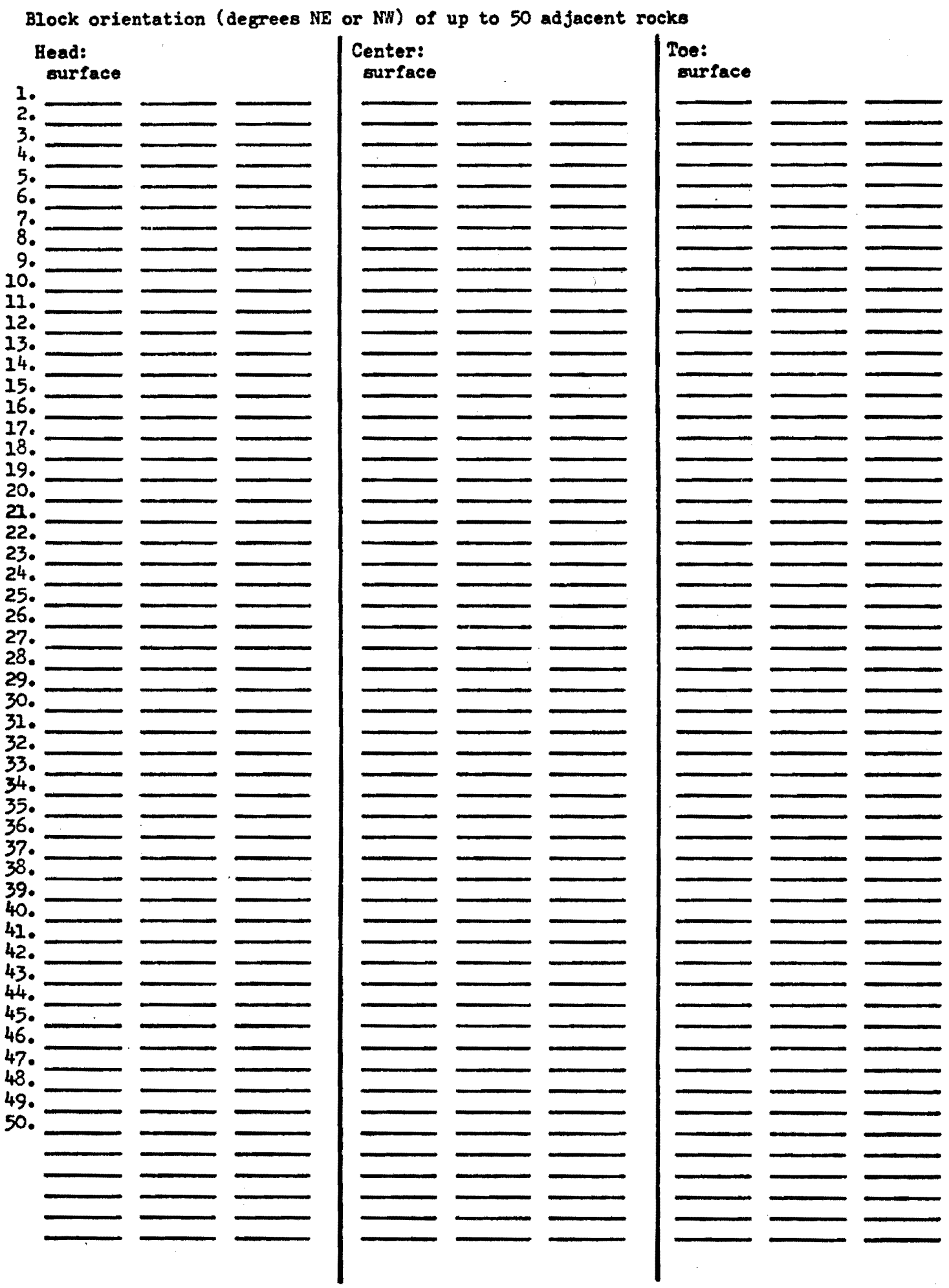




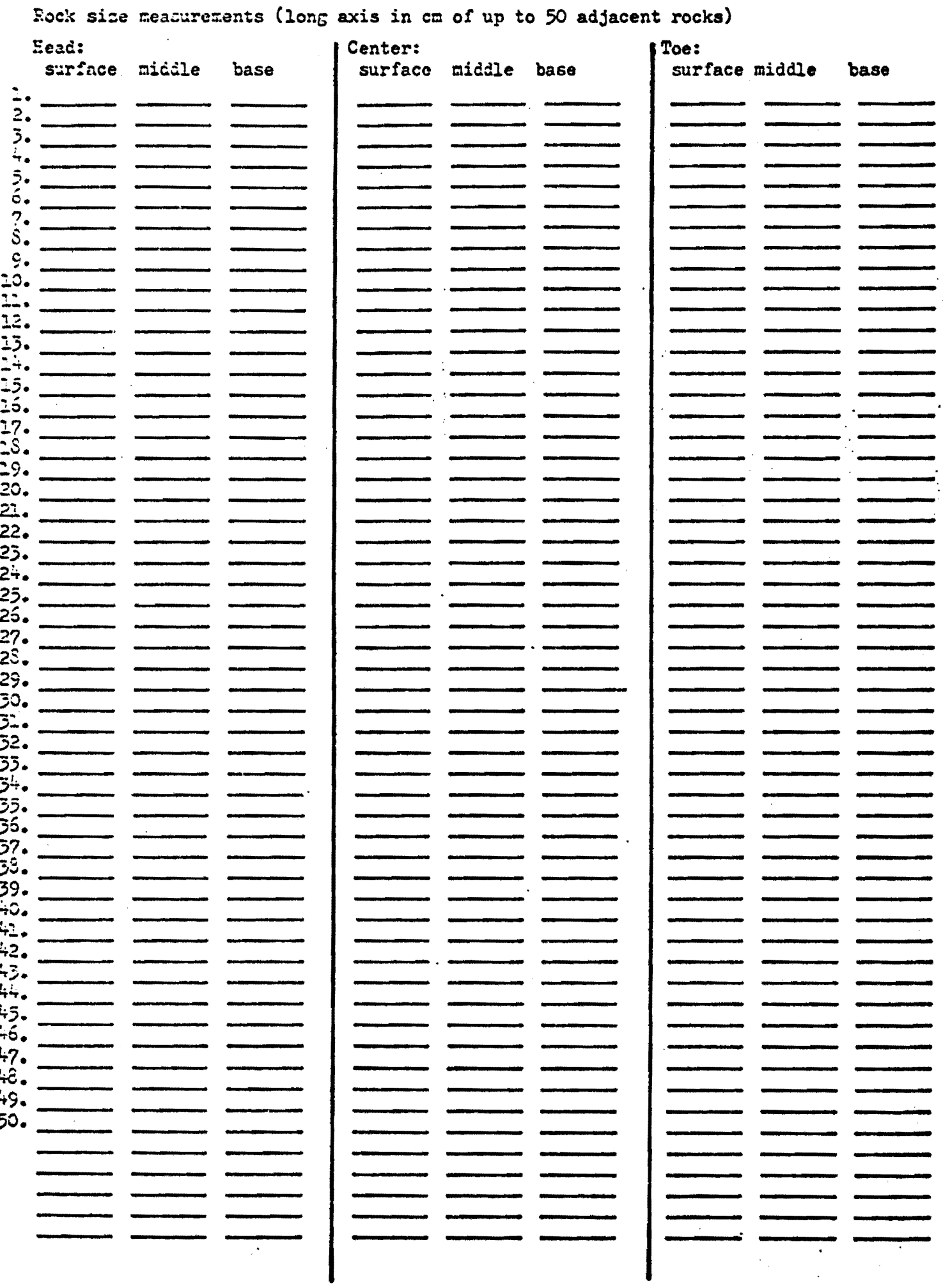

